\title{
Dialectics of Rural Change: A Political Economy of Livelihoods and Land Use and Land Cover Change in Rural Western Kenya
}

Naomi Yieko Shanguhyia

West Virginia University

Follow this and additional works at: https://researchrepository.wvu.edu/etd

\section{Recommended Citation}

Shanguhyia, Naomi Yieko, "Dialectics of Rural Change: A Political Economy of Livelihoods and Land Use and Land Cover Change in Rural Western Kenya" (2013). Graduate Theses, Dissertations, and Problem Reports. 362.

https://researchrepository.wvu.edu/etd/362

This Dissertation is protected by copyright and/or related rights. It has been brought to you by the The Research Repository @ WVU with permission from the rights-holder(s). You are free to use this Dissertation in any way that is permitted by the copyright and related rights legislation that applies to your use. For other uses you must obtain permission from the rights-holder(s) directly, unless additional rights are indicated by a Creative Commons license in the record and/ or on the work itself. This Dissertation has been accepted for inclusion in WVU Graduate Theses, Dissertations, and Problem Reports collection by an authorized administrator of The Research Repository @ WVU.

For more information, please contact researchrepository@mail.wvu.edu. 


\title{
Dialectics of Rural Change: A Political Economy of Livelihoods and Land Use and Land Cover Change in Rural Western Kenya
}

\author{
Naomi Yieko Shanguhyia \\ Dissertation submitted to the \\ College of Arts and Sciences \\ at West Virginia University \\ in partial fulfillment of the requirements \\ for the degree of \\ Doctor of Philosophy \\ In \\ Geography \\ Brent McCusker, Ph.D., Chair \\ Timothy Warner, Ph.D. \\ Robert Maxon, Ph.D. \\ Jeremia Njeru, Ph.D. \\ Edna Wangui, Ph.D. \\ Department of Geology and Geography \\ Morgantown, West Virginia \\ 2013
}

Keywords: dialectics, rural change, rural livelihoods, land use and cover change, neoliberalism, Kenya

C) 2013 Naomi Shanguhyia 


\title{
ABSTRACT \\ Dialectics of Rural Change: A Political Economy of Livelihoods and Land Use and Cover Change in Rural Western Kenya
}

\author{
Naomi Yieko Shanguhyia
}

This study examines the political economy of livelihoods and land use and land cover change in rural western Kenya during a period of economic change. The research findings are presented in three stand-alone papers. The first paper examines the initiatives and policies implemented by the state in the past three decades of neoliberal economic change and the implications for rural development. Policy documents and data obtained from interviews and surveys were used to examine how a shift in policies impacted three sectors of rural development: agriculture, infrastructure and commerce- in Vihiga County. The results indicate two politicaleconomic moments that redefined the role of the state in development. The first moment which is associated with the reluctant adoption of neoliberal economic policies, registered poor macroeconomic performance but maintained sustained support for rural households. The second moment which was marked with enhanced implementation of neoliberal policies saw impressive macro-economic performance, but with declining state support for rural households. The role of the state changed from being at the forefront of the development to providing an enabling environment for private enterprises to initiate and implement rural development programs.

The second paper focuses on the livelihood activities of rural households in Vihiga County, in the wake of neoliberal economic change. Using a mixed method approach, the study examines the current livelihood diversification options available for households and the changes to these options since Kenya's development agenda shifted from being state led to being market-driven. The findings show that the adoption of neoliberal economic policies contributed to the shrinking of livelihood diversification options for many households that are already grappling with sociocultural strains in the face of declining farm sizes. Many households have become poorer, cannot afford to educate their children and are chronically food-insecure. The few households that engage in cash crop production are vulnerable to both economic perturbations due to their heavy dependence on the market and to environmental perturbations such as erratic rainfall patterns.

The third paper examines the spatial dimensions of rural change over a 25 year period of neoliberal economic change, from the vantage point of land use and land cover change. The analysis combines social and spatial methods and draws from Neil Smith's and David Harvey's political economic theory to examine the production of nature and space on the rural landscape. Change detection done using Landsat imagery indicates some changes that include simultaneous loss and regeneration of forest cover, and expansion of road infrastructure. Other observable changes include some horizontal and vertical expansion of peri-urban centers. These landscape changes reflect on-going processes of enhanced capital penetration and commodification of nature which are associated with neoliberal economic policies. 


\section{ACKNOWLEDGEMENTS}

I would not have been able to complete this dissertation were it not for the support and guidance of a number of people. I am greatly indebted to my academic mentor and advisor, Dr. Brent McCusker, whose patience, guidance and encouragement has enabled me navigate the challenges of doctoral studies. I am equally grateful to my doctoral dissertation committee members, Dr. Timothy Warner, Dr. Robert Maxon, Dr. Jeremia Njeru and Dr. Edna Wangui, for their insightful and enthusiastic support for my work. I consider myself to be extremely fortunate to have had such an excellent team in my corner.

This research was made possible through a Doctoral Dissertation Research Improvement grant (No. 1029111) from the National Science Foundation (NSF), the Global Education Opportunities grant from WVU Office of International Programs and WVU Eberly College Doctoral Dissertation Travel grant. I am very grateful to these institutions for the financial support. I am also indebted to the Department of Geology and Geography at West Virginia University for the financial support in the form of Graduate Teaching Assistantships while doing my coursework. I am also thankful to the families in Vihiga County who consented to participate in this research as well as the various government officials and local leaders for their invaluable support during my fieldwork.

I owe a lot to my parents, Edna and Hunter Silabeya who, in spite of not having any college education themselves, have been my most ardent cheerleaders. I know for a fact that I would not have come this far in my pursuit of higher education, were it not for their encouragement. I also want to thank my husband Martin and our three children - Ivayo, Yanza and Imani - for their relentless support and patience during this roller coaster experience of dissertation writing which took up most of our family time. Now that I am done, I hope I will be able to make it up to you somehow!

Finally, and of most significance, I acknowledge God's grace that has been sufficient and without which I would not accomplish any of this. 


\section{DEDICATION}

For Ivayo, Yanza \& Imani, and for all the children of Vihiga.

May the change that you experience in your lives be meaningful!

Nyasaye Abakasie 


\section{Table of Contents}

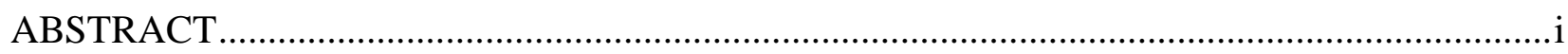

ACKNOWLEDGEMENTS ...........................................................................................

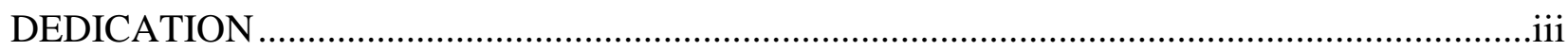

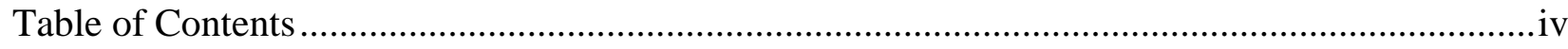

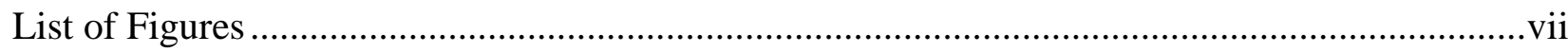

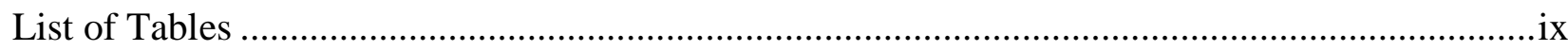

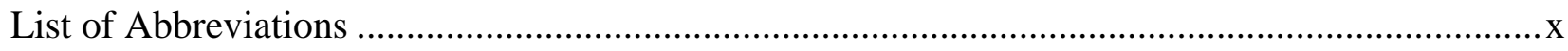

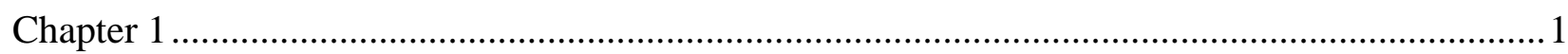

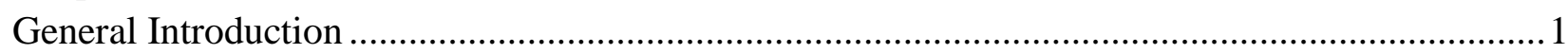

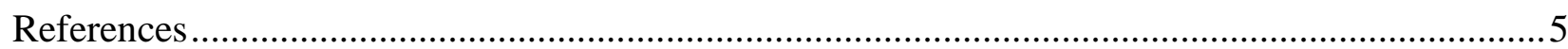

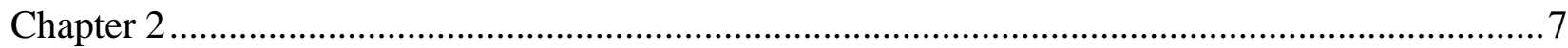

A Political Economy of Rural Change: Neoliberal Economic Policies and rural development in

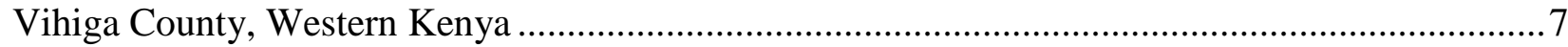

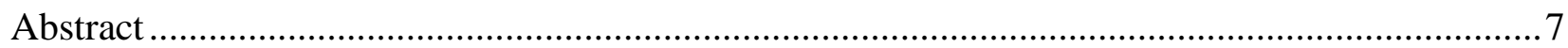

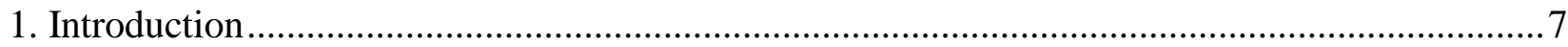

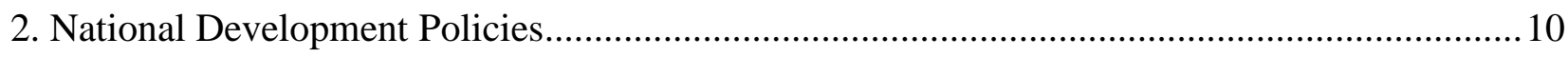

2.1. Structural Adjustment Programs in Kenya, 1980 - 2000.................................................... 10

2.3. Poverty Reduction Strategies Papers (PRSPs) ………………………............................... 12

2.4. Vision 2030: Medium Term Plan - 2008 - 2012 ………………………………............. 14

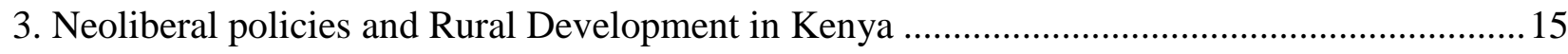

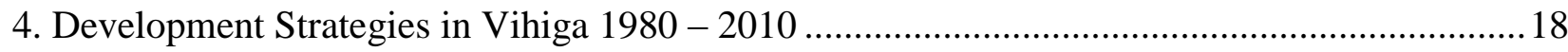

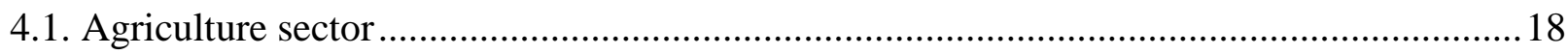

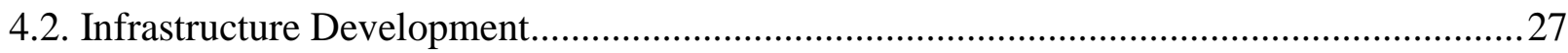

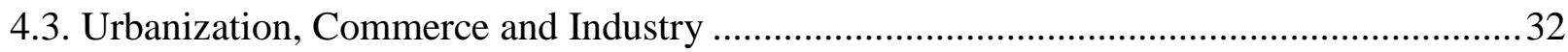

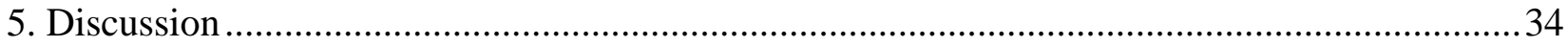

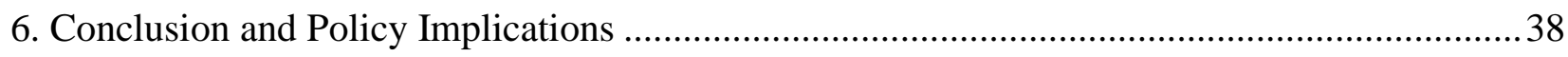

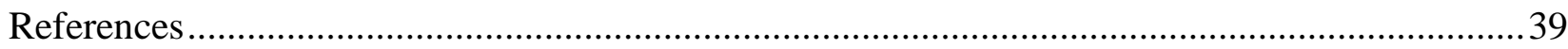

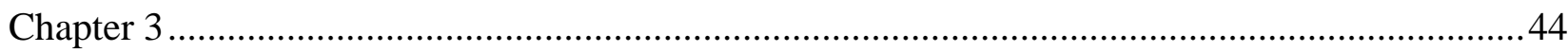

"Living Like we are in the City": Changing Rural Livelihoods in a period of Rapid Economic

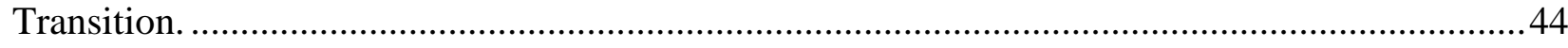

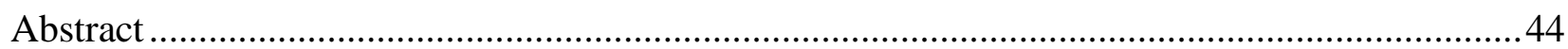

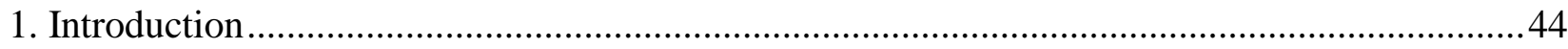

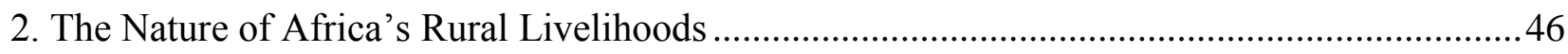

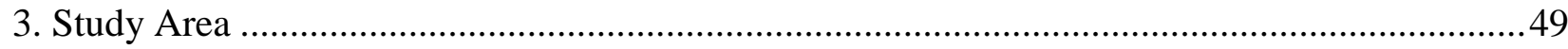




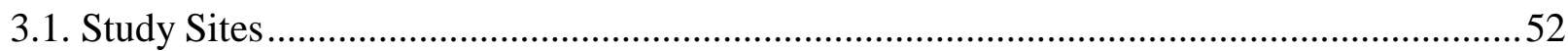

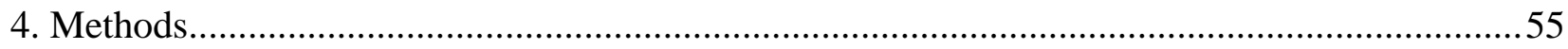

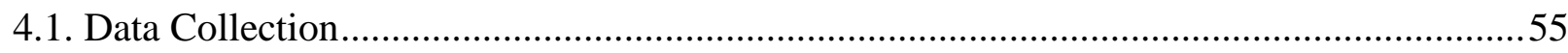

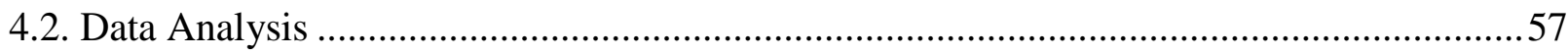

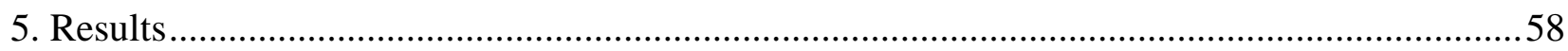

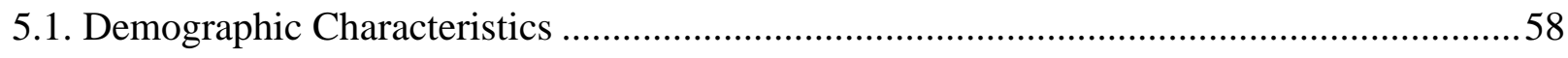

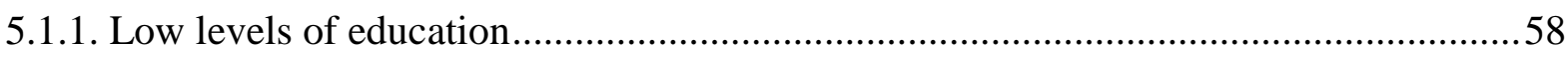

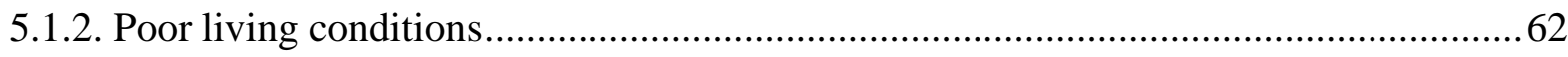

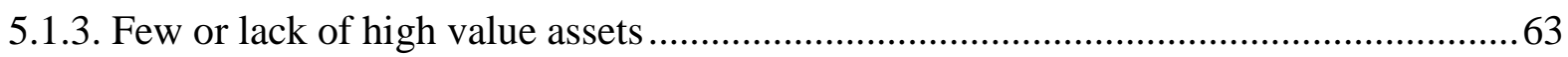

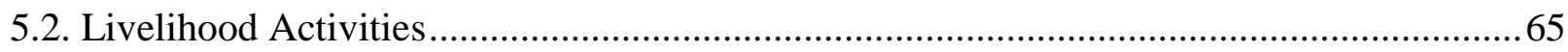

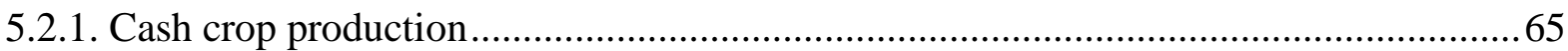

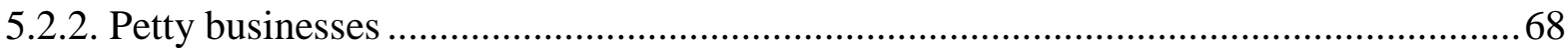

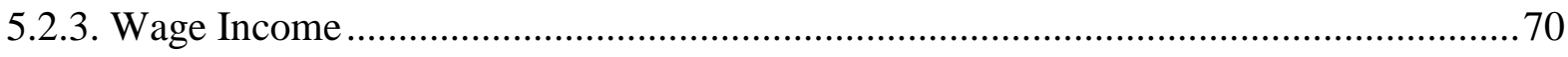

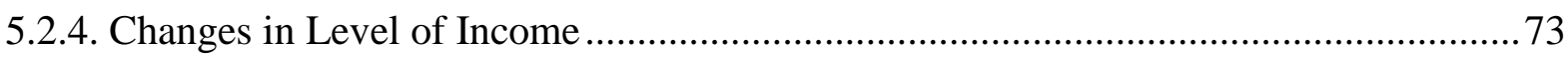

5.3. Land Use Strategies and Implications for Food Security ....................................................74

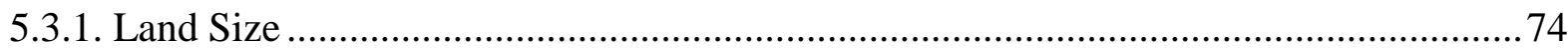

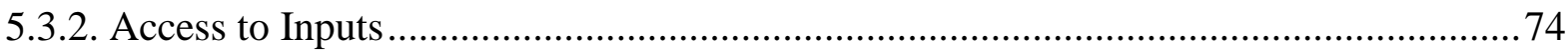

5.3.3. Variations in Rainfall Patterns......................................................................................

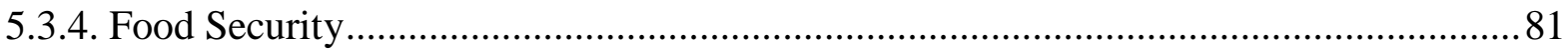

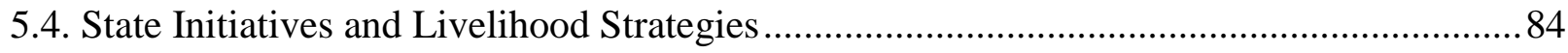

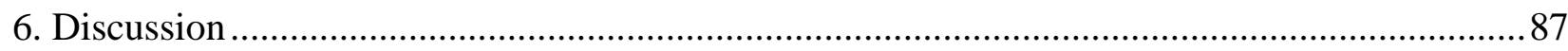

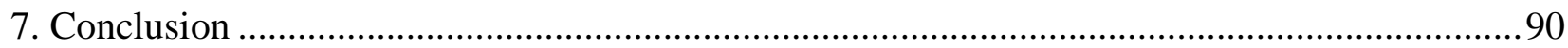

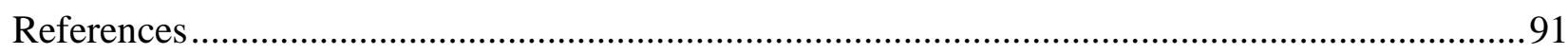

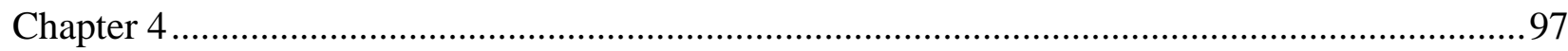

Capital Penetration, Commodification of Nature and the Production of Rural Space: Examining Land Use and Land Cover Change in Western Kenya ...............................................................97

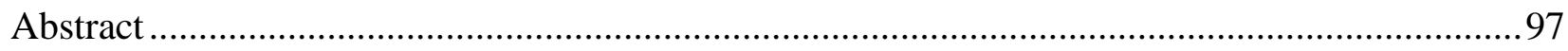

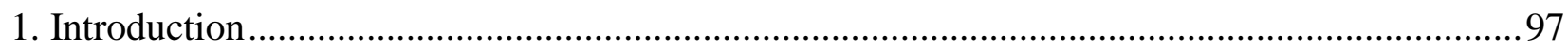

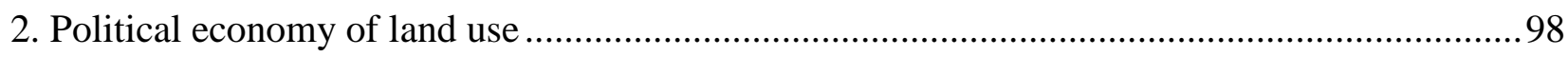




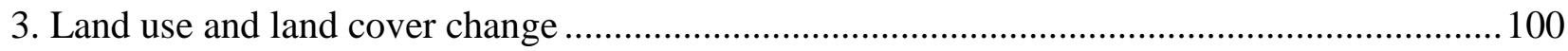

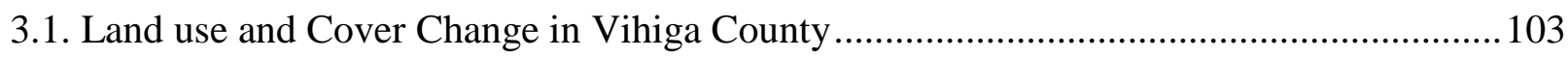

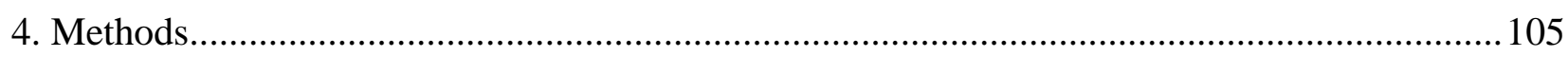

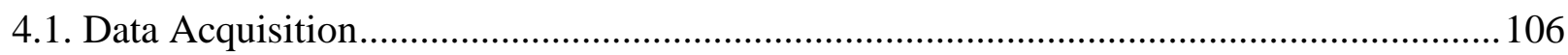

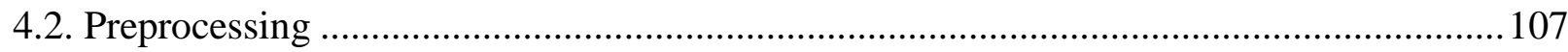

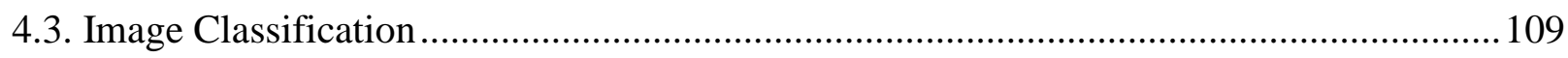

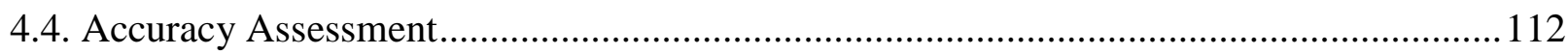

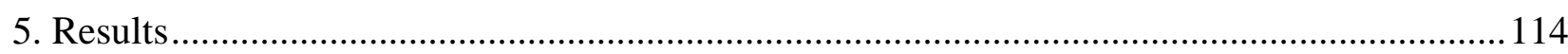

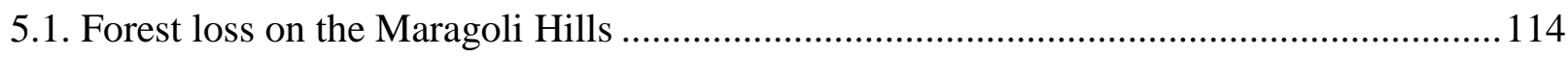

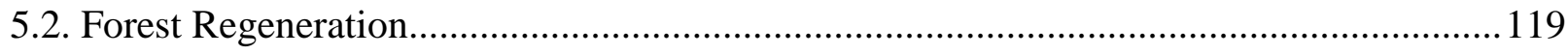

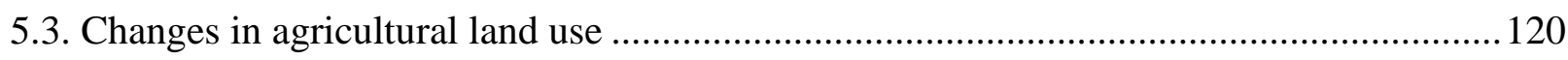

6. Capital penetration, commodification of nature and the production of rural space...................124

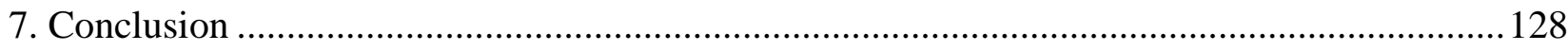

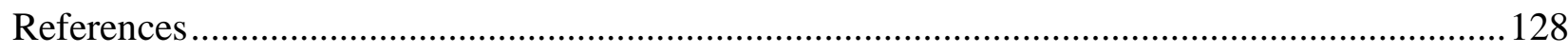

Chapter 5

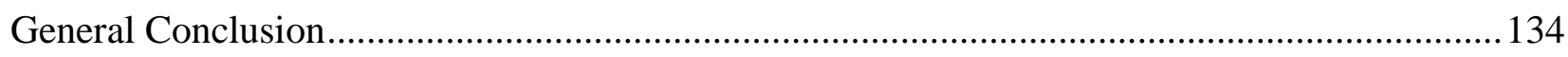




\section{List of Figures}

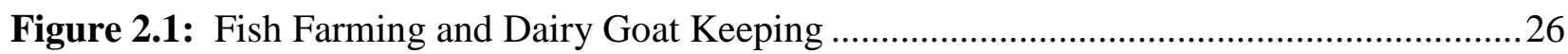

Figure 2.2: A sign for one of the Emuhaya CDF sponsored rural access roads ............................29

Figure 2.3: Domestic water sources that include springs (on left) and rain water harvesting........32

Figure 2.4: The Luanda "Modern" Market and inside the Mudete Tea factory ..............................33

Figure 3.1: Location of Vihiga County, Kenya ………..........................................................50

Figure 3.2: Vihiga County Administrative Locations ...............................................................53

Figure 3.3: Household educational expenditure after the introduction of Free Primary Education

Figure 3.4: Respondents level of education by gender...........................................................5

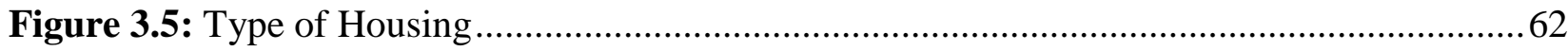

Figure 3.6: Impact of prolonged dry spells on the tea crop ............................................................66

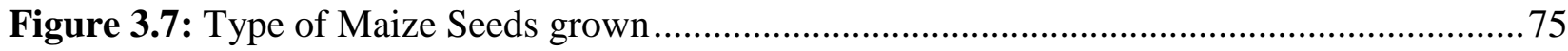

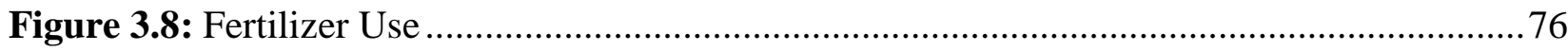

Figure 3.9: Kisumu Station Decadal Rainfall 1960 - 2010........................................................78

Figure 3.10: Kakamega Station Decadal Rainfall 1960 - 2010 .......................................................79

Figure 3.11: Kisumu and Kakamega Stations Annual Rainfall, 1960 - 2010 ................................8 80

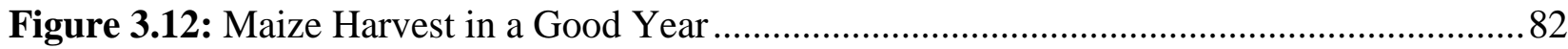

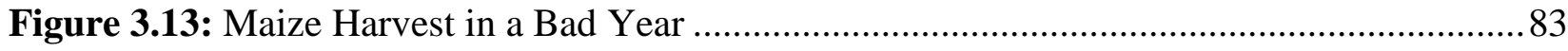

Figure 4.1: False Color composties of Landsat Images of Vihiga County with Bands 4, 3 \& 2 as

Red, Green and Blue, a.) 1/16/1985, b.) 2/5/2001 7 c.) 12/23/2010 ............................................109

Figure 4.2a: Land Cover Map for January 16, 1985 ..............................................................111

Figure 4.2b: Land cover map for February 5, 2001.............................................................111

Figure 4.2c: Land Cover Map for December 23, 2010...........................................................112

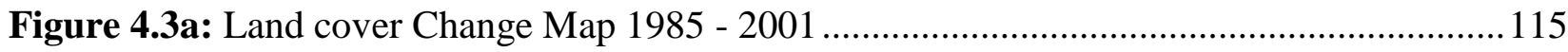

Figure 4.3b: Land Cover Change Map 2001 - 2010 ..................................................................115 
Figure 4.4: Farms and homes on the Maragoli Hills in the foreground overlooking Lake Victoria

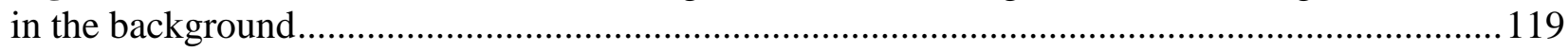

Figure 4.5: Cultivation of tea and eucalytpus trees ....................................................... 121

Figure 4.6: Peri-urban expansion of market centers as shown in 1978 aerial photos (on left) and

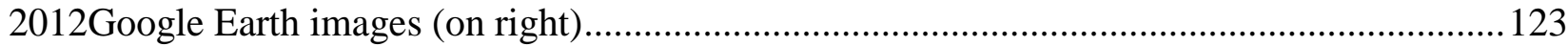

Figure 4.7: Vertical Expansion of market centers as shown in new developments on the right

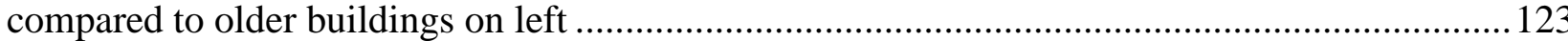




\section{List of Tables}

Table 3.1: Respondents' and Spouse's main occupation ....................................................6 60

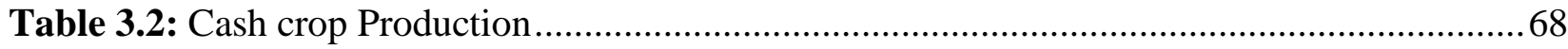

Table 3.3: Types of businesses members of the study households engage in. ..........................69

Table 3.4: Percentage of Household members in Salaried employment ................................. 71

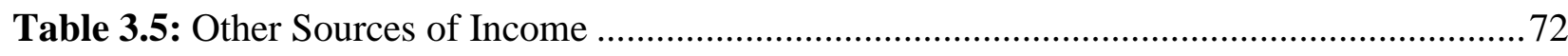

Table 3.6: Local perceptions on the Importance of State - funded development projects.............86

Table 4.1: Error Matrix for the 1985 Land Cover Map: Overall Accuracy 86.7\%; Kappa 0.752

Table 4.2: Error Matrix for the 2001 Land Cover Map: Overall Accurary 88.7\% ; Kappa 0.801

Table 4.3: Error Matrix for the 2010 Land Cover Map: Overall Accuracy 87.7\%; Kappa 0.772

Table 4.4: Areal extent of the different land cover classes 1985, $2001 \& 2010$ (in hectares) ..... 114 


\section{List of Abbreviations}

ADB - Africa Development Bank

CDF - Constituency Development Fund

DDC - District Development Committee

DDO - District Development Officer

DDP - District Development Plan

DFRD - District Focus for Rural Development

ERS - Economic Recovery Strategy

ESP - Economic Stimulus Plan

GDP - Gross Domestic Product

GOK - Government of Kenya

KKV - Kazi Kwa Vijana (Jobs for the Youth)

KNTC - Kenya National Trading Corporation

IFAD - International Fund for Agricultural Development

IFIs - International Financial Institutions

IMF - International Monetary Fund

KTDA - Kenya Tea Development Authority

MDGs - Millennium Development Goals

MNCs - Multi National Corporations

MTP - Medium Term

NAAIAP - National Accelerated Agricultural Input Access Program

NALEP - National Agriculture Livestock Extension Program

NARC - National Rainbow Coalition

NCPD - National Cereals and Produce Board

NGO - Non-governmental Organization

PRSP - Poverty Reduction Strategy Paper

ROK - Republic of Kenya

RPK - Resource Project of Kenya

SAPs - Structural Adjustment Programs 
SIDA - Swedish International Development Agency

USAID - United States Agency for International Aid

WTO - World Trade Organization 


\section{Chapter 1}

\section{General Introduction}

This dissertation is made up of three stand-alone papers presented in Chapters 2 through 4, which are based on research that was conducted in a predominantly rural County in western Kenya. The main objective of this research is to examine the socio-spatial nature of rural change in western Kenya during a period of rapid economic change, which in this case is defined by the transition from state-led development to more market driven development that is espoused in the neoliberal economic reforms that were adopted globally in the 1980s and 1990s. This chapter is a brief general introduction to the study and includes the theoretical background and a brief overview of the findings presented in the three derivative papers.

Rural change in sub Saharan Africa continues to attract studies with varying ideological and analytical approaches that attribute the problems of chronic poverty and hunger that plague these communities to insufficient or incomplete integration into the global economy. Bernstein (2007) classified these analytical positions in three categories. The first analytical category, which he referred to as the "primordial thesis" attributes the lack of capitalist development on the continent to the inherent social dynamics of ethnicity and kin that prevent the operation of rational markets. Goran Hyden's (1980) “economy of affection” thesis is an example of this ideological stance. The second analytical approach attributes Africa's disposition to its skewed integration into global economy that began in earnest during the colonial period and which continues to prevent the full manifestation of capitalist development on the continent. This approach has undercurrents of the dependency theory and attributes underdevelopment to external causes. The third and final analytical category identified by Bernstein is attributed to Sara Berry's (1993) No Condition is Permanent in which she views the central cause of uneven development on the African countryside as a dialectic of change and continuity with origins in the colonial period. Consequently, capitalism enhances the already existing inequalities such as patriarchy and ethnicity. In Berry's view, penetration of capital and commodification of land disadvantages certain social groups such as women while also benefitting others. 
This research draws from Neil Smith's theory of uneven development and its defining concepts of production of space and nature as the underlying explanations of uneven geographical development of capitalism. Johnston et al. (2000) noted that this political economy perspective derived from Marx and his modern interpreters offers the geographer a general theory in which historically and locally specific events can be related to one another in a broader context. Smith's (2008) more comprehensive definition introduced the notion that capitalism produces nature and space as it expands and this is what is evident as uneven development:

Uneven development is both the product and the geographical premise of capitalist development. As product, the pattern is highly visible in landscapes of capitalism as the difference between developed and underdeveloped spaces at different scales. As the premise of further capitalist expansion, uneven development can be comprehended only by means of a theoretical analysis of the capitalist production of space and nature (p. 206).

The production of nature thesis is based on the unity of nature and society. Marx saw the labor process as an integral part of the interactive process between nature and society (Smith 2008). Smith sought to draw a distinction between the bourgeois and the Marxian conceptions of nature. He further argued that Marx was concerned with the actual process which might achieve the unity of man and nature and put human labor at the center of the relationship between human beings and nature. Viewed from this perspective, therefore, the process of appropriating human labor to alter nature is seen as the social production of nature. He further argued that capitalism has replaced a non-human first nature with a socially produced second nature. Uneven development therefore is a manifestation and consequence of the concrete process and pattern of the production of nature under capitalism. With the production of nature comes the alteration of space. The alterations of spatial relations brought about by the simultaneous alteration of the form of concrete pieces of matter are an integral part of the production of nature (Smith \& O'Keefe 1980). Production of space thus asserts the unity of society and space. How capitalism produces space and nature is the critical underlying principle to understanding uneven development. Driven by the need to accumulate, capital is always seeking for ways to increase surplus value. This is achieved either through adoption of improved technology or relocating to spaces where the cost of production is less. According to Harvey (1982), uneven geographical development is the outcome of capital's attempt to secure a spatial fix to overcome the barriers to 
accumulation. Thus the contradictory tendencies toward differentiation and equalization determine the capitalist production of space. Viewing nature and society dialectically by Marxists is the basis for the method referred to as dialectical materialism.

This study sought to examine three dimensions of rural change: livelihoods, land use and land cover change, and the role of the state. More specifically, the study attempted to address the following research questions:

i. What initiatives and policies has the state implemented in the past three decades of neoliberal economic change and what have been the implications for rural development?

ii.In what ways have the livelihood activities of rural households in Vihiga changed over the past three decades of rapid economic change?

iii. What are the spatial dimensions of rural change during this period of economic transition?

This study used mixed methods to analyze the socio-spatial nature of rural change. Such an approach is useful for examining different dimensions of an issue or trend. The use of spatial techniques captures the spatial moments/forms of change, while the use of qualitative and quantitative data teases out the underlying processes of this change. The analysis draws from Ollman's (1993) and Harvey's (1996) dialectics. Dialectics is a way of thinking that brings into focus the full range of changes and interactions that occur in our world (Ollman 1993).

Dialectical thinking emphasizes the understanding of processes, flows and fluxes and relations over analysis of elements, things, structures and organized systems (Harvey 1996). Marx's ontology conceives of reality as a totality that is composed of internally related parts and these parts are expandable such that each one in the fullness of its relations can represent the totality (Ollman 1993). The world according to Marx consists of an infinite number of mutually dependent processes with no clear or fixed boundaries that coalesce to form a loosely structured whole or totality.

The use of dialectics in analyzing rural change dynamics enables the possibility of "viewing" rural change from different vantage points. Vantage point is a place within the relationship from which to view, think about and piece together the other components in the relationship (Ollman 1993). In this research, the three vantage points that are used are livelihood 
change, land use and land cover change and the role of state policies. It is from these three vantage points that the three papers that make up this dissertation are written.

The first paper presented in Chapter 2 examines the changes in Kenya's political economy over the past two to three decades of neoliberal economic change and the implications for rural development in Vihiga. This analysis, though not intended to privilege the agency of the state over other actors, acknowledges its critical role in defining the opportunities and constraints that rural communities are faced with. It therefore sets the stage for the subsequent analysis of livelihoods and land use and land cover change. An analysis of various government policy documents and reports, as well as key informant interviews with government officials yielded information on past and present state initiatives on rural development. Household surveys and interviews also provided some insights on the community's perspectives on these state initiatives. The results indicate a shift in the government approach to rural development from initiatives that targeted individual households to investing more in improving infrastructure. Such projects which accelerate the penetration of capital appear to benefit a small group of individuals while making it possible to access the market that rural communities present.

The second paper presented in Chapter 3 examines rural change from the vantage point of livelihood change with the household being the unit of observation. Using data obtained from household surveys, interviews and focus group discussions, this paper examines the various ways in which rural households in Vihiga County are negotiating the challenges and opportunities presented in a changing political economy. The lack of baseline data on past livelihood activities meant that the respondents' subjective comparisons of present and past activities were used as an indicator of livelihood change. The findings of this analysis show a community whose livelihood options have shrunk significantly as most of the safety nets that they have relied on over the years have gradually diminished. Contrary to the commonly held notion of rural households having a diverse portfolio of livelihood activities, households in this area appear to have very few options for diversification and are highly vulnerable to exogenous events such as erratic rainfall.

The final paper, presented in Chapter 4, examines the spatial dimensions of rural change from the vantage point of land use and land cover. In this chapter, Landsat imagery from 1985, 
2001 and 2010 is used to perform a change detection analysis while data obtained from household surveys and interviews provide some information on the underlying processes and relations of the observed change. The coarse spatial resolution of Landsat imagery, however, means that only changes occurring at a larger spatial scale were observed. The results show a landscape that is undergoing transformations as market centers expand and improved infrastructure enables the enhanced penetration of capital into areas that were previously inaccessible. While changes around forest areas was observable on the Landsat imagery, much of the expansion of market centers was seen to occur in a more vertical than horizontal manner due to scarcity of land. A juxtaposition of aerial photos taken in the 1970s and 2012 Google earth images of three of these market centers shows minimal spatial expansion, but observations made during research visits showed a more vertical expansion, where most of the new buildings are multi-storeyed. These market centers offer a variety of services that include banking and financial services, as well as internet services that serve to link rural communities to the rest of the world.

The final chapter of this dissertation highlights the main findings of this study as presented in Chapters 2 through 4 and notes some of the limitations of viewing rural change from these three vantage points.

\section{References}

Bernstein H. 2007. Capitalism and the Moral Economy: Land Questions in sub Saharan Africa. Paper presented at the Conference on Poverty and Capital, Global Poverty Research Group and Brooks World Poverty Institute, University of Manchester, 2-4 July 2007.

Berry S. 1993: No Condition is Permanent: Social Dynamics of Agrarian Change in sub Saharan Africa. University of Wisconsin Press, Madison, WI.

Harvey D. 1982. Limits to Capital. Blackwell Publishers, Oxford

Harvey D. 1996: Justice, Nature and the Geography of Difference. Blackwell Publishers, Oxford.

Hyden G. 1980. Beyond Ujamaa: Underdevelopment and the Uncaptured Peasantry. University of California Press, Berkeley, CA. 
Johnston R. J., Gregory D., Pratt G. \& Watts M. (eds.), 2000. The Dictionary of Human Geography. 4th Ed. Blackwell Publishers, MA.

Kitching G. 1980. Class and Economic Change in Kenya: The Making of an African Petite Bourgeois, 1950 - 1970. Yale University Press, New Haven, CT.

Ollman B. 2003. The Dance of the Dialectic: Steps in Marx's Method. University of Illinois Press, Urbana and Chicago.

Ollman, B. 1993. Dialectical investigations. Routledge, London.

Smith N. \& O'Keefe P. 1980. Geography, Marx and the Concept of Nature. Antipode 12 (2):3039

Smith N. 2008. Uneven Development: Nature, Capital and the Production of Space. 3rd Ed. University of Georgia Press, Athens, GA. 


\title{
Chapter 2
}

\section{A Political Economy of Rural Change: Neoliberal Economic Policies and rural development in Vihiga County, Western Kenya}

\begin{abstract}
This paper examines the initiatives and policies implemented by the state in the past three decades of neoliberal economic change and the implications for rural development. An analysis of policy documents and data obtained from interviews and surveys were used to examine how the shift in policies impacted three sectors of rural development - agriculture, infrastructure and commerce - in Vihiga County. The results indicate two political-economic moments that redefined the role of the state in development. The first moment marked with the reluctant adoption of neoliberal economic policies registered poor macro-economic performance but maintained sustained support for rural households. The second moment was marked with enhanced implementation of neoliberal policies and realized impressive macro-economic performance, but with declining state support for rural households. The role of the state changed from being at the forefront of the development agenda to that of providing an enabling environment for private enterprises to initiate and implement rural development programs.
\end{abstract}

\section{Introduction}

On September $16^{\text {th }}$ 2011, President Mwai Kibaki signed the Price Control (Essential Goods) Act 2011 into law, more than a year after the Bill was passed in parliament. According to the Special Issue of the Kenya Gazette Supplement No. 121 (Acts No. 26) of September 19 2011 , the new law is an "Act of Parliament to provide the regulation of the prices of essential commodities in order to secure their availability at reasonable prices and for connected purposes" (Kenya Gazette No. 121 2011, p. 722). This Act, which gives the Minister for Finance the powers to declare certain goods "essential" and "determine the maximum prices of the commodities" (p. 722), received mixed reaction from different stakeholders. While most Kenyans lauded the move as long overdue in the wake of the escalating inflation, the business community, manufacturers as well as farmers all decried what they termed as the "draconian and anti-business" nature of the law. Previously, the President had declined to sign the Bill after it was passed in parliament, maintaining that as a member of the World Trade Organization, Kenya was bound by the National Treatment Agreement and could not contravene its free market 
stipulations regarding price control. To this end, Article 2(2) of the new law requires the Minister (of Finance) to "take into account any relevant treaty or convention ratified by Kenya" (p. 722) in enforcing the law, thus presenting a challenge of how to implement the law.

The Price Control (Essential Goods) Act 2011 received mixed reactions from various sections of the Kenyan community. Some dismissed it as another of the President's populist moves to appease the Kenyan masses hard pressed by the high cost of living occasioned by escalating inflation. But whether there may be some truth in this line of thought is beside the point. The reality is that most Kenyans are struggling to make ends meet and expect the government to act more proactively to ease their burden and therefore such a law that protects them from the negative effects of the free market is, in their view, long overdue. The President's earlier comments, which are reflected in the new law with regard to the free market stipulations espoused by the WTO, capture what can be read as the dilemma of the state in the neoliberal era. Although recent rhetoric by leading world leaders following the global financial crises has indicated the end of neoliberalism as we know it, this has not changed the policies that drive neoliberalism globally and which are enforced by global organizations like the World Trade Organization (WTO) and which are enforced by the state.

The state in the era of economic neoliberalism is viewed as a facilitating agent for the uninhibited operations of capital that entail "maximization of entrepreneurial freedoms within an institutional framework characterized by private property rights, individual liberty, free markets and free trade" (Harvey 2006, p.145). The neoliberal economic ideology, which gained global momentum three decades ago with the help of the International Financial Institutions (IFIs) continues to be presented as the inevitable road map for development for many countries in the global south and many other parts of the world. For developing countries in Africa especially, neoliberal policies were touted as the only avenue out of stagnated, poverty-riddled underdevelopment. Governments were encouraged to embrace policies that would enhance integration into the global economy as opposed to inward looking policies that would nurture industrialization at the national level (Rowden 2010, Harvey 2010, World Bank 1994). But as early as the 1990s, these same policies were under scrutiny for their failure to address the needs of vulnerable groups in these countries as reports of increasing inequality and marginalization became common (Moseley et al. 2010, Rowden 2010, Bond 2006, Ferguson 2006, Cline-Cole \& 
Harrison 2010). Harvey (2006) argues that this was precisely what these policies were meant to achieve in the first place.

According to Harvey (2006), "neoliberalism is a political project concerned both to reestablish the conditions of capital accumulation and the restoration of class power" (p. 149). Viewed from this perspective therefore, neoliberalism has succeeded in consolidating capital in the hands of a few individuals while impoverishing the majority. The neo-liberal state is not the "neutral, disempowered umpire in social and economic affairs" (Mahao 2009, p.74) but a tool appropriated by the ruling class to facilitate the process of accumulation by dispossession (Harvey 2006, Spie $\beta$ 2004). Harvey further identifies four elements of this process of accumulation by dispossession to be privatization, financialization, management and manipulation of crises and state redistributions. Privatization entails commodification of public assets and transfer of public assets to private companies while financialization involves acceleration in "manipulative, speculative and predatory" financial transactions that serves the interests of a few individuals at the expense of many (Harvey 2006, p. 154).

This chapter examines the various ways in which two of these four elements, privatization and financialization, feature in Kenya's development policy since the country embraced neoliberal economic policies and the implications for rural development. More specifically, the analysis focuses on the implications of these policies on peasant/smallholder agriculture which is the mainstay of rural livelihoods, development of infrastructure and commerce. Central to this analysis is the facilitating role played by various state agents as managers of "that which private capital is unwilling to or unable to do" and as they seek to "expedite and arbitrate the stable expansion of capitalism" (Smith 2008, p. 72). Harvey (2010) describes the state alongside capital as the "main agents at work in producing and reproducing geography of the second nature around us" (p. 185).

This chapter/paper also draws from the narratives on development in Vihiga as indicated and/or implied in development documents and other forms of communication. Data for this chapter was obtained from key informant interviews, household surveys and policy documents produced by various departments at both national and County/District levels and analyzed as outlined in Section 4 of Chapter 3. The chapter is structured to include a brief overview of the 
genesis and progression of neoliberal development policies in Kenya from 1980 to 2010 as reflected in various policy documents and how this was operationalized in planning rural development in Vihiga during the same period. Finally, a brief discussion on how this trajectory reflects the four elements of accumulation by dispossession identified by Harvey (2006) concludes this analysis. The next section is a brief overview of the adoption and subsequent trajectory of neoliberal economic policy adoption in Kenya.

\section{National Development Policies}

\subsection{Structural Adjustment Programs in Kenya, 1980 - 2000}

Kenya's adoption of neoliberal policies took off in an erratic manner that was not impressive to the IFIs and other bilateral donor agencies. Like most developing countries, Kenya experienced internal and external shocks in the 1970s that had significantly impacted on the economy in a negative way. With the guidance of the World Bank, Kenya designed its national development policy within the framework of neoliberalism in the mid-1980s. This policy document, the Sessional Paper No. 1 of 1986 on Economic Management for Renewed Growth, spelled out the measures that needed to be taken for the country to make economic progress.

Chief among these measures was the need to reduce state control over the economy while making way for the private sector to take a more central role in the country's development.

Since gaining independence in 1963, Kenya like most countries across the continent had maintained a state-led development agenda in which the government maintained a proactive and leading role in defining the scope and direction of development projects while protecting the upcoming infant industries. In line with this strategy, the Kenya government created a number of state managed institutions (parastatals) in key sectors of the economy such as agriculture, industry, transport and communications, commerce and finance to implement the government development agenda. Such parastatals included the National Cereals and Produce Board (NCPB), which was in charge of the nation's food reserves and oversaw the production and storage of major cereals like maize, wheat and rice. 
Neoliberal economic strategy, however, called for greater participation of the private sector with minimal state intervention in economic planning, a move that required that either institutions such as the NCPB were privatized or dismantled to give way for the "free market" to operate without inhibitions. The government was also required to remove subsidies from products such as farm inputs and price controls on local and imported products that were critical for the sustainability of the agricultural sector - a major source of revenue for the economy and national food security. These were among the requirements stipulated in the Structural Adjustment Program (SAP) packages and whose fulfillment became conditionality for receiving donor aid.

The Kenyan government under President Moi, however, was a reluctant partner in the process of neoliberal change and initially failed to fully commit itself to the implementation of these policies. This apparent lack of commitment on the part of the GOK, together with concerns about poor governance were the basis of an impasse between the government and bilateral donors in the late 1980s and early 1990s (World Bank Report 1996). Donor aid, which the government had come to rely on to balance its budget, was withheld as international and local nongovernmental organizations became the conduit for donor development funds.

By early 1992, Kenya's economic performance was abysmal with a GDP growth rate of less than 1\% recorded that year. A Welfare Monitoring Survey taken in 1994 indicated that income inequality was also becoming pronounced with the richest $20 \%$ of households receiving $62 \%$ of the total income (World Bank Report 1998). The perceived lack of commitment and reluctance of the Kenyan government to implement the SAPs irked the World Bank officials who pledged to create a development crisis in Kenya to force the country to "forge a domestic consensus and initiate extraordinary reforms" (World Bank Report 1998, p. 10). On its part, GOK indicated in its policies and development plans, perhaps to justify its lack of commitment, that the implementation of SAPs jeopardized the welfare of its people. The frustration of the state in trying to balance the needs of its citizens and the demands of the IFIs was captured in the 1994 - 1996 National Development Plan;

Kenya has always tried to implement development policies with her people's welfare in mind. However, in unavoidable circumstances like during the implementation of Structural Adjustment Programs (SAPS), it may not be possible to achieve both goals simultaneously. (p. 4) 
Such sentiments, reflecting a besieged state, continued to permeate most of the government policy documents which reiterated that the role of the government in economic development was now "considerably reduced to providing an effective regulatory framework, essential public infrastructure and social services" while "relying on the market forces to drive the economy" (ROK 1996, p. 9).

With the economy in crisis, GOK was left with no option but to bow to pressure from the World Bank and IMF in order to receive donor aid. In 1993, GOK agreed to implement more reform measures that included "elimination of import taxes, reduction of civil service, elimination of price controls and restrictions on maize marketing and reduction in the role of National Cereals and Produce Board (NCPB)" (World Bank Report 1996, p. 3). These measures led to the early retirement of more than 79,000 civil servants between 1991 and 2002 as part of the restructuring of the civil service (ROK - ERS 2003), while the government relinquished its shares in the parastatals as part of the privatization of state firms. But even this was not enough to stop the IMF from suspending its loan disbursement citing persistent governance issues and lack of will on the part of the government to address these issues. In the meantime, the impact of SAPs on livelihoods in developing countries became a contentious issue as research indicated that the number of people living below the poverty line was on the rise. The need to have policies that were designed by the governments themselves was seen to be inevitable and this led to the emergence of the Poverty Reduction Strategies (PRSPs).

\subsection{Poverty Reduction Strategies Papers (PRSPs)}

Although PRSPs are drafted by individual governments, they have to be endorsed by the IMF and World Bank for the country to qualify for donor funds. Most donor agencies are willing to only fund and support activities that are included in the PRSPs yet these documents give little priority to sectors that are considered critical for poverty reduction such as agriculture (Swallow 2004). Kenya drafted her first Interim Poverty Reduction Strategy Paper in 2000, a move that saw IMF resume lending for a short period of time. It was not until elections were conducted and the new coalition government of the National Rainbow Coalition (NARC) took over the leadership in 2002 that efforts to win donor confidence were renewed. NARC pledged major 
reforms aimed at "eradicating corruption, reviving the ailing economy and execute programs to restore the support of IMF and World Bank" (Shiverenje 2005, p. 30). Eager to start on a "clean slate' without the baggage of the previous regime, the NARC government revised the PRSP draft to incorporate their vision for accelerated economic growth and the NARC Manifesto (GOK ERS 2003). The resultant policy document was the Economic Recovery Strategy for Wealth and Employment Creation 2003 - 2007 (ERS) which was designed to focus on three broad areas that fit in what was referred to as "pillars" of development that included "strengthening economic growth, enhancing equity and reducing poverty, and improving governance" (World Bank 2004, p. 5).

As part of its strategy to 'improve' Kenya's 'image' and 'relationship' with donor agencies, the NARC government outlined an ambitious plan for addressing contentious governance issues that were associated with Moi's administration. The ERS further indicated the willingness of the new regime to embrace neoliberal economic policies without inhibitions and so one of the measures indicated for strengthening economic growth was "unleashing of the private sector participation and investment" as well as privatization of public firms. The strategy had the intended effect and by the end of 2003, Kenya was back on the World Bank lending case list and was in line to receive donor funds to implement the ERS (World Bank 2004). Among the projects the Bank was keen on supporting included the reform and privatization of parastatals, restructuring of the financial sector, promoting private sector development and improving infrastructure as the basis of economic growth and reducing barriers to trade. Development plans within the second pillar of equity and poverty reduction were designed with the Millennium Development Goals (MDGs) as the benchmark and included the provision of universal free primary education, provision of basic health services for the poor and the vulnerable, increasing agricultural productivity and improving the incomes for the poor.

With donor and investor confidence resumed, Kenya's economy recovered to record an impressive average GDP growth rate of $6 \%$ between 2004 and 2007. This impressive macroeconomic performance, however, did not have a significant impact on the widening inequality as reports indicated wider inequality gaps existed in 2005 (during this period of rapid economic growth) compared to 1997 when the economy was performing poorly (World Bank 2010). Furthermore, efforts to improve governance had very minimal positive outcomes. 
Regional inequality in Kenya is exacerbated by the culture of political patronage which became entrenched in Kenya's post-colonial political economy. This was one of the underlying issues that fueled the post-election violence in early 2008 that eventually resulted into an economic regression/stagnation. This situation was made worse by external conditions that included the international financial crisis and ecological issues such as the drought in October and November 2008. The grand coalition government that took over power in 2008 designed a new development agenda, embodied in the Vision 2030, which though it took in to consideration the different political agenda of the two principals (the President and the Prime Minister), was designed to "propel the country to the next level of development".

\subsection{Vision 2030: Medium Term Plan - 2008 - 2012}

Vision 2030 is the latest in the series of development plans designed by the Kenyan government and the second by the post-Moi regime under Mwai Kibaki. It was launched in early 2007 and its objectives are very similar to its predecessor, the ERS. The implementation, however, is designed in five year phases referred to as Medium Term Plans (MTP) with the current one being the MTP 2008 - 2012. Like the ERS, Vision 2030 and subsequently the MTPs are structured around three pillars - economic, social and political. The economic aspect of the MTP focuses on the various important sectors of the economy, the social aspect on the issues of poverty and equity while the political one focuses on issues of governance. The Plan's target was to raise the GDP growth rate to $12 \%$ per annum by the year 2012, a figure that most Kenyan economists consider to be ambitious, considering the uncertainties in the global economy and the existing political tensions in the country.

This brief review highlights some of key moments in Kenya's development trajectory where neoliberal economic agenda replaced the state-led development policies. While Moi was a reluctant adopter and implementer of neoliberal economic policies in the form of SAPs, Kibaki's government readily embraced this approach, ushering in an era of uninhibited free market policies. The next section focuses on how these changes were implemented at local levels. 


\section{Neoliberal policies and Rural Development in Kenya}

Rural areas form the backbone of Kenya's economy with over $80 \%$ of the country's population residing on the countryside. It is in these rural areas that agriculture, which is the mainstay of the economy, is practiced on both large commercial farms and small family farms. The agricultural sector contributes about $26 \%$ to the GDP and a further $27 \%$ in linkages with the manufacturing, distribution and service related sectors (ROK 2005). The development of the rural areas is therefore critical to the country's overall development and an assessment of how national development policies are implemented in rural areas can shed some light on their overall effectiveness.

Over the course of the past three decades, the government has adopted various strategies for reaching out to the rural communities in the country with varying levels of success. These efforts at decentralization have mainly focused on implementing the national policies at the lower levels of administration, often focusing on the District as the planning and implementation unit for rural development policies. National Development Plans "contain(s) a broad policy framework for attaining goals within a specified Plan period" while District Development Plans that are drafted by the District Development Officers are "policy implementation documents and thus translate policy objectives of the NDP into implementable activities" (ROK 1996, p. 59). State officers at the district level act as the link between the rural population in their jurisdiction and the central government based in Nairobi.

Although numerous previous attempts had been made to adopt some form of decentralization in post-independent Kenya, it was not until the District Focus for Rural Development (DFRD) was introduced that this strategy was meaningfully adopted and gained some relevance. Proponents of decentralization argue that "rural development proceeds more rapidly where there exists a process of consultation and bargaining between the state and rural populations." (Barkan \& Chege 1989, p. 433). President Moi launched the DFRD in 1986 in a bid to "achieve regional balance in growth and in provision of infrastructure and basic needs services" (National Development Plan 1989 - 1993, p. xx). The president stated that: 
The strategy, which makes the districts centers for planning, implementation and management of rural development, has several positive dimensions. First the people will be directly involved in the identification, design, implementation and management of projects and programs. This will make development to be more consistent with the needs and aspirations of wananchi. Secondly, the decision making structure will center around districts themselves. Thirdly and most fundamentally, the allocation of resources will be shared more equitably, by being directed to the areas of most need. (Daniel arap Moi, Speech made on March 6 1985)

This move saw the previously dormant District Development Committees (DDCs) and their presiding officers, the District Development Officers (DDOs) gain some relevance as they were now charged with the responsibility of preparing annual reports and anticipated budgetary needs for the districts. However, because this strategy focused on government institutions it failed to draw the people into the decision making process and only served to alienate them further (Barkan \& Chege 1989). Critics also argue that this strategy was actually meant to be a political tool that Moi used to restructure the social base that he had inherited from Kenyatta (ibid). Under the DFRD, funds meant for developing rural areas were allocated to districts and subsequently to different development projects. More districts were created as part of the strategy to decentralize administration and "bring development closer to the people". This approach, however, failed to effectively address the problem of inequality between regions in the country since it lacked the necessary legal framework to guide its implementation. Most of the development projects were funded through harambees $^{1}$ (fund-raisings) rather than through the District Development Office.

By 2002 when NARC took over leadership under President Kibaki, rural development in Kenya was highly uneven with enclaves of affluence existing alongside masses of destitution and a different strategy was needed to address this disparity. The Constituency Development Fund (CDF) was established by an Act of Parliament in 2003 to address imbalances in regional development, reduce the Member of Parliament's burden of fundraising and ensure citizen participation in the processes of project identification, implementation and monitoring (TISA 2011, Obuya 2008). The Act stipulates that $2.5 \%$ of the total government revenue be allocated to

\footnotetext{
${ }^{1}$ The 'harambee' (Swahili for “pulling together”) culture was initiated by Kenya's first postindependence president, Jomo Kenyatta and popularized by his predecessor, Daniel arap Moi. It is a self-help approach to development that involves raising funds for public projects through collective contributions from members of the public often at public gatherings where local dignitaries and other guests are invited.
} 
the CDF kitty, of which $75 \%$ is distributed equally among the 210 constituencies and the remaining $25 \%$ allocated based on the constituency poverty level and population size and therefore shifting the development focus from the district to the constituency (Revised CDF Act, 2007). Every constituency has a CDF Committee which is convened by the sitting Member of Parliament and made up of fifteen members representing different socio-economic groups and stakeholders. The CDF Committee evaluates project proposals received from locational development committees and prioritizes them based on the allocated funds. So far, CDF has been credited for implementing projects that have improved schools, health facilities, roads and other forms of infrastructure. However, it has also been riddled with claims that politicians are using it as a political tool to boost their careers and to reward their supporters while research indicates that citizen participation remains poor in most constituencies with less than $40 \%$ of the population being involved, leading to low project ownership (Kimenyi 2005, Bagaka 2008, TISA 2011).

In 2008, Kenya's economy took a nosedive after the post-election violence that rocked the country earlier in the year, recording a GDP growth rate of $1.7 \%$ compared to $7.1 \%$ recorded in 2007. In response to this poor performance, the government launched the Economic Stimulus Program (ESP) in 2009 with the aim of jumpstarting the economy. In his speech during the launch, the Minister for Finance stated that:

In response to the current challenges and to avert a further slide in the expansion of our national cake, we plan to implement a fiscal stimulus package that focuses on sectors that will generate maximum benefits. (Uhuru Kenyatta, August 17 th 2009 Speech while launching the ESP)

Projects under ESP include improvement of schools and health facilities, construction of fresh produce markets and jua kali sheds, irrigation based agriculture, construction of fish ponds and tree planting. ESP and CDF projects run side by side but unlike the CDF, funds for ESP projects are disbursed through different ministries and departments. There is a lot of overlap in fund allocation and types of projects funded by the two programs and many of the people interviewed in this study, including local administrators, could not adequately distinguish between these two sets of projects. The next section of this paper focuses on the implementation of development policies in Vihiga County, western Kenya. 


\section{Development Strategies in Vihiga 1980 - 2010}

Prior to 1991, the current area administratively known as Vihiga County (or District until 2007) was part of Kakamega district, one of the three districts that made up the Western Province of Kenya. Four administrative divisions in the southern part of the district including Emuhaya, Vihiga, Sabatia and Hamisi were later carved out of this massive district in 1991 to create Vihiga District. In 2007, Vihiga District was subdivided further into four districts, Vihiga, Emuhaya, Hamisi and Sabatia while the original district became Vihiga County under the new system of devolved government adopted in the new constitution in 2010. This section analyses the development trajectory of the current Vihiga County that includes Emuhaya, Hamisi, Sabatia and Vihiga districts.

Sources of data used in this analysis include District Development Plans (DDPs) which are released periodically to coincide with and reflect the national development agenda reflected in the National Development Plans (NDPs). While District Development Plans cover a wide range of issues, this analysis limits itself to four areas that are considered critical indicators of rural development. These include agriculture, infrastructure, education, and commerce/industry. This analysis focuses on six development plans that include, 1984 - 1988 (Kakamega District), 1989 1993 (Kakamega District), 1994 - 1996 (Vihiga District), 1997 - 2001 (Vihiga District), 2002 2008 (Vihiga District), 2008 - 2012 (new Emuhaya \& Vihiga Districts). Other sources of data include documents and reports produced by different government units at the district level as well as interviews and surveys conducted in the area between 2010 and 2011. Data collection and analysis proceeded as outlined in Section 4 of Chapter 3.

\subsection{Agriculture sector}

The agriculture sub-sector is very important to Kenya's economy and contributes more than $26 \%$ of the national GDP. At the district level, the agriculture and livestock offices are charged with the responsibility of providing extension services, managing and controlling of pests and diseases, collecting and disseminating agricultural related information and implementing and coordinating sector programs. In Vihiga, over $90 \%$ of the population relies mainly on agriculture 
for their livelihood and therefore the success with which projects are implemented becomes a good indicator of well-being.

The 1980s was a difficult period for the then Kakamega district with $64 \%$ of the agricultural projects proposed in the 1979 - 1983 planning period not implemented mainly due to financial constraints. One of the major proposals included the construction of a tea factory in the district. Tea is one of Kenya's major source of export earnings and source of income for households in this area including those with parcels of land that are smaller than half a hectare. The proposal for the construction of a tea processing plant in the district during that development cycle was shelved because there wasn't sufficient tea produced in the district to warrant a new factory. During the next planning period $(1984-89)$ it was proposed that Kenya Tea Development Authority (KTDA), which was then a parastatal, be requested once again to construct the factory so that its presence could become an incentive for the local farmers to start planting tea.

Most households in this region use a large proportion, if not all, of their land to grow food crops that include maize, beans, sweet potatoes, bananas, millet and sorghum. Agricultural reports indicated that there was need to increase the production of these crops. Due to the size of their farms, most of the food produced by the households in the southern part of Kakamega district was for subsistence. One of the identified challenges improved food production was the cultural practice of continuous sub-division of family land among sons, subsequently reducing the amount of land available for each household to subsist on. This was the case in the southern divisions of the district (present day Vihiga County) where production could only be increased through intensive use of improved seeds and fertilizers. Prioritization and selection of projects during this phase was done to conform to the directives of the then newly released District Focus for Rural Development Strategy.

During the 1984 - 1988 planning period, the government planned to organize for and fund demonstration sessions in different parts of the district to "teach farmers how to increase the yield per hectare through the use of certified seeds, fertilizers and manure and better pest control" (Kakamega District Development Plan 1984 - 1988, p. 37). Small scale farmers could access farm inputs and credits through the Cooperative Bank of Kenya, Kenya Farmers' Association 
(KFA), cooperative societies, the District Agricultural office and from private outlets across the district for those who could afford to buy them. In spite of shortcomings in transportation facilities, manpower and administrative capacity, the government-run National Cereals and Produce Marketing Board enjoyed a monopoly in marketing and transporting maize from the maize surplus to the maize deficit parts of the district.

Unfortunately, improvement in the crop production envisaged in the $1984-88$ plan failed due to poor weather. It was indicated in the subsequent plan for the $1989-93$ planning period that the yield for most of the crops was lower than expected and there was significant potential for increasing it by $30 \%$. The plan proposed to increase the production of every crop grown in the district by $5 \%$ every year during the planning period. In tandem with the national policy on food production, the goals of the district were to increase productivity by promoting the use of improved varieties of crops and improving extension, pricing and marketing services. The plan also proposed encouraging farmers to diversify production in favor of cash crops like tea, coffee, and horticultural produce to increase incomes. This strategy alongside dairy and poultry farming were expected to absorb the excess labor in the southern divisions of the District. Cooperative societies were expected to play a leading role in pricing and marketing of produce.

In the livestock sub-sector, farmers were encouraged to abandon the local Zebu cattle and instead keep exotic dairy livestock in zero grazing units as part of the modernization strategy and to increase production. The livestock officers embarked on a project aimed at castrating Zebu bulls so as to maintain pure bred imported dairy cows. This move was met with resistance from some farmers who argued that exotic livestock were susceptible to East Coast fever. The government was expected to provide artificial insemination services as well as maintain and staff communal cattle dips to control ticks. To improve livestock production, the 1989-93 plan proposed increasing the coverage of the administration of artificial insemination services to areas that were not covered and increase the number of cattle dips in the district. It was noted that zerograzing had taken off well in the southern part of the district where farmers had small landholdings leading to increased milk production.

After it was carved off from Kakamega District in 1991, Vihiga District had its first development plan during the 1994-1996 plan period with national Sessional Paper No.1 of 1986 
on Economic Management for Renewed Growth used as a guide. It was noted that contrary to projections made during the previous planning period, crop and livestock production had gone down, turning the District into a net importer of food. The plan also noted that increasing population, poor roads, inadequate socio-economic infrastructure and lack of skilled personnel were some of the constraints to development in the district. Without departing from previous plans however, the 1994 - 96 plan proposed to increase productivity through enhanced extension service work and improved farmer access to agricultural credit to enable them acquire farm inputs. More specifically, the plan targeted to increase maize yield from 1.69 to 1.83 tons per hectare, increase bean yield from 0.51 to 0.65 tons per hectare, increase tea output from $6.4 \mathrm{~kg}$ to $7.5 \mathrm{~kg}$ per bush and coffee yield from 4.0 tons to 5.65 tons per hectare. Methods previously proposed for improving livestock production such as promoting the use of cattle dips were indicated for improving production during this plan period. Funding for projects during this phase was expected to come from International NGOs such as UN International Fund for Agricultural Development (IFAD), United States Agency for International Development (USAID), Swedish International Development Agency (SIDA) and World Bank. Most of the projects however did not take off or were abandoned after donors withdrew funding during the 1995/96 financial year.

Tea and horticultural production went up during this period with crops like tomatoes, French beans, kale and onions gaining in yield per hectare. A private firm, Hortiequip, that engaged farmers on contract basis to grow French (string) beans played a significant role in this trend. Farmers contracted by this firm received credit in the form of insecticides, seeds and fertilizer that was used specifically on the French (string) beans. Due to the policy of market liberalization adopted by the state, NCPB lost its monopoly in maize marketing and private millers and sellers were allowed to trade in maize. In 1996, the NCPB did not purchase or transfer any maize from and into the district. Tea produced in the district was delivered to KTDA factories in the neighboring districts as there was still no tea factory constructed in Vihiga.

The agenda to encourage farmers to engage more in horticultural production was carried on in the 1997 - 2001 DDP. The rationale given for this policy was that such crops would find market outlets in the nearby urban areas of Kisumu, Kakamega, Busia and Bungoma and other peri-urban areas within the district. However, the poor performance of the Kenyan economy in 
the late 1990s had repercussions for funding of agricultural activities in Vihiga. There was a marked decline in the agricultural extension activities in the district due lack of transportation and demonstration materials. Even then, tea continued to dominate as a source of income for the farmers who had planted sufficient bushes while coffee continued to decline. The decline in coffee production was attributed to management wrangles in the Coffee Board of Kenya while the increase in tea production led to the construction of Mudete Tea Factory in Sabatia division by KTDA. The factory, which began operating in 1997 was constructed with an African Development Bank (ADB) loan and was expected to have the capacity to process 15 million kilograms of green leaf per year. By 2000, tea covered a total of 1,800 hectares with a total of 12,000 farmers enrolled as tea growers. One of the challenges these farmers faced however was the cost of labor since tea is a labor intensive crop.

The decline in maize yield was attributed partly to the inability of farmers to cope with the striga weed invasion that destroyed $40 \%$ of the crop. The production of French beans also declined and gradually came to an end after Hortiequip closed its operations in the district. Fruits like avocados, bananas and papayas continued to be a seasonal source of income for some households. Papaya market in the district however also declined after Mashambani Industries at Gambogi market, a local industry that had been producing juice, jam and latex from papayas closed down after its products failed to compete favorably against cheaper imported products.

With its theme as Rapid Industrialization for Sustainable Development, the 1997 - 2001 Plan proposed development strategies for addressing constraints to development. The constraints identified included lack of adequate infrastructure, underdeveloped human resources, inadequate and poorly developed raw materials, poor marketing and inaccessibility to credit facilities. Once again, failure to obtain government funds during this development phase meant that less than a half of the proposed projects were implemented. However, farmers benefitted somewhat from an influx of private extension providers such as the Resource Project of Kenya (RPK), Christian Partners Development Agency, American Breeders Society and the Heifer Program International that infiltrated the area during this period.

The main theme of the Vihiga District 2002 - 2008 development plan was Effective Management for Sustainable Economic Growth and Poverty Reduction. In line with this theme, 
the vision of the agricultural sub sector was "sustainable and equitable rural development for all" while its mission was to "to contribute to poverty reduction through the promotion of food security, agro-industrial development, trade, water supply and sustainable utilization of natural resources". The objective of the agriculture sub-sector was to focus on the production of high value crops in collaboration with other stakeholders. The strategy for agricultural extension under the National Agriculture Livestock Extension Program (NALEP) and funded by the Swedish International Agency (SIDA) was to help farmers identify and design activities to improve productivity. The NALEP project adopted a "focal area approach" where farmers from an identified geographical area were brought together with the aim of designing projects that were suitable for their area. The project's underlying objectives are to "provide enabling environment for private sector participation in extension" and to "educate, train and equip farmers with knowledge, skills and attitude to consider farming as a business and the farm as an enterprise" (ROK 2008: 42).

The change in the country's leadership in 2003, introduced a new dimension in the approach to rural development through the introduction of the Constituency Development Fund (CDF). The CDF has since become the conduit through which rural development is to be pursued through funding most of the projects in the district during the 2002-2008 planning phase. Most of the projects funded by the $\mathrm{CDF}$ during this period were not directly under the agriculture subsector.

Following the splitting up of the district into four smaller districts in 2007, each district prepared a different DDP for the 2008 - 2012 plan period. These plans were designed to reflect the country's development goals as stipulated in Vision 2030 and its first year implementation framework - the Medium Term Plan (MTP) 2008 - 2012. Being the first ones designed in the post-Moi era, the DDPs bore detailed and elaborate foreword from the Minister of State for Planning, National Development and Vision 2030 which emphasized the role of development partners and the private sector in realizing their goal. With the government now channeling development funds through the $\mathrm{CDF}$, fewer development projects are indicated in the plans. But these two recent phases have seen an influx of development collaborators engage in various projects to improve agricultural development in the district. While some like NALEP have been 
going on for a while and have district-wide projects, some focus on smaller areas and sponsor projects that only last for a year or two.

In addition to more collaborators and development partners, the district now has many organizations offering credit loans to households in the area. Some of the organizations like Kenya Women Finance Trust and Africa Now offer loans for petty trade to supplement farm income, while others like Equity Bank offer loans known as Kilimo Biashara (Agriculture Business) for boosting agricultural productivity. Some of the farmers however have been reported to avoid these credit opportunities due to the experiences of previous defaulters. In addition to the projects already ongoing in the district, in 2009, the government sponsored commercial fish farming in the district as part of the countrywide Economic Stimulus Program that was aimed at resuscitating the economy after the 2008 post-election violence.

In spite of the programs that have been initiated in Vihiga, the area remains a net food importer form neighboring districts like Bungoma, Nandi, Transnzoia, Kisumu and Busia. Government efforts through the agricultural extension office focus on adoption of horticulture but the extension staff are too few to make visits to all the farmers who need them. Most of the farmers interviewed complained that they have not seen agricultural extension workers in their area in a long time and had to rely on private practitioners with questionable credentials for veterinary services. The Vihiga District Agricultural Officer indicated that due to staff shortage, the office had adopted a policy where farmers who needed extension services had to visit the district agricultural office and request for such a visit. Since this is too much of a hassle for most of the farmers, many preferred to either use their discretion and experience or seek the advice of other less knowledgeable individuals. For instance, farmers were relying on advice from stockists and shopkeepers in choosing the type of seeds and fertilizer to purchase. This has become even more complex with a wider variety of seeds and fertilizers that are on the market. The result is that farmers end up buying inappropriate inputs which lead to poor outcomes in farm productivity.

Even projects designed to provide free inputs for the farmers like the National Accelerated Agricultural Input Access Program (NAAIAP) have made little significant impact. But the agriculture officers insist that it is the size of the land that is the problem: 
NAAIAP provides farmers with fertilizer and seeds $-50 \mathrm{~kg}$ bag of fertilizer and $10 \mathrm{~kg}$ of seeds that is sufficient for one acre of land. Once farmers are provided with these inputs, they are expected to produce a certain level of yield when all the factors are favorable. The challenge however is the land sizes and the unpredictable weather. Because of the land sizes, it is very difficult for us to give the farmers the quantities of the fertilizer and seeds recommended by the government. So what we do, we split into two and instead of reaching 1000 farmers, we reach 2000 farmers. This is done in the hope that the farmers are able to get a harvest from which they can keep some of it which they can sell at the right time to purchase more inputs. However, this idea is not working because of the land sizes. The farmers are not able to produce enough to store - they consume all the produce. (Otieno Agundwa, Division Crops Officer - Luanda Division, 12/30/2010 - Personal Communication)

Some of the ESP projects such as fish farming (Fig. 2.1) were introduced in a selective manner and were not accessible to all the households who expressed interest. Only a total of six farmers and two self-help groups participated in this project in the three locations where fieldwork was conducted. Some of the farmers and administrators indicated a lot of disapproval in the way that participants for these projects were selected while the participants had reservations on the availability of a ready market for the fish. But the Member of Parliament for Emuhaya disputed that marketing the fish would pose a problem:

There is market for the fish. We cannot even exploit the full market - the European Union.... The target market is the local market and from there if there is surplus, we go to the international market. Fish has a big market internationally. Apart from that, we have to reach a certain threshold of fish production before we start thinking about exporting, we have not reached that threshold. So it is a package, we have people in the cooperative union, they must have a cooperative society, they have to set up their offices, acquiring fish, the fish foods, they have to acquire how to market.... so it is a whole package. (Wilbur Ottichilo, Emuhaya MP, 12/29/2010)

However, by the time of carrying out this fieldwork, the fish farmers had not received the necessary training and were less optimistic than their legislative representative. The dairy goat farming projects (such as the ones shown in Fig. 2.1) also appeared to be faced with similar challenges with the farmers receiving little support and training. One of the women groups interviewed in South Maragoli had lost their dairy goats due to inappropriate feeds and lack of treatment. 

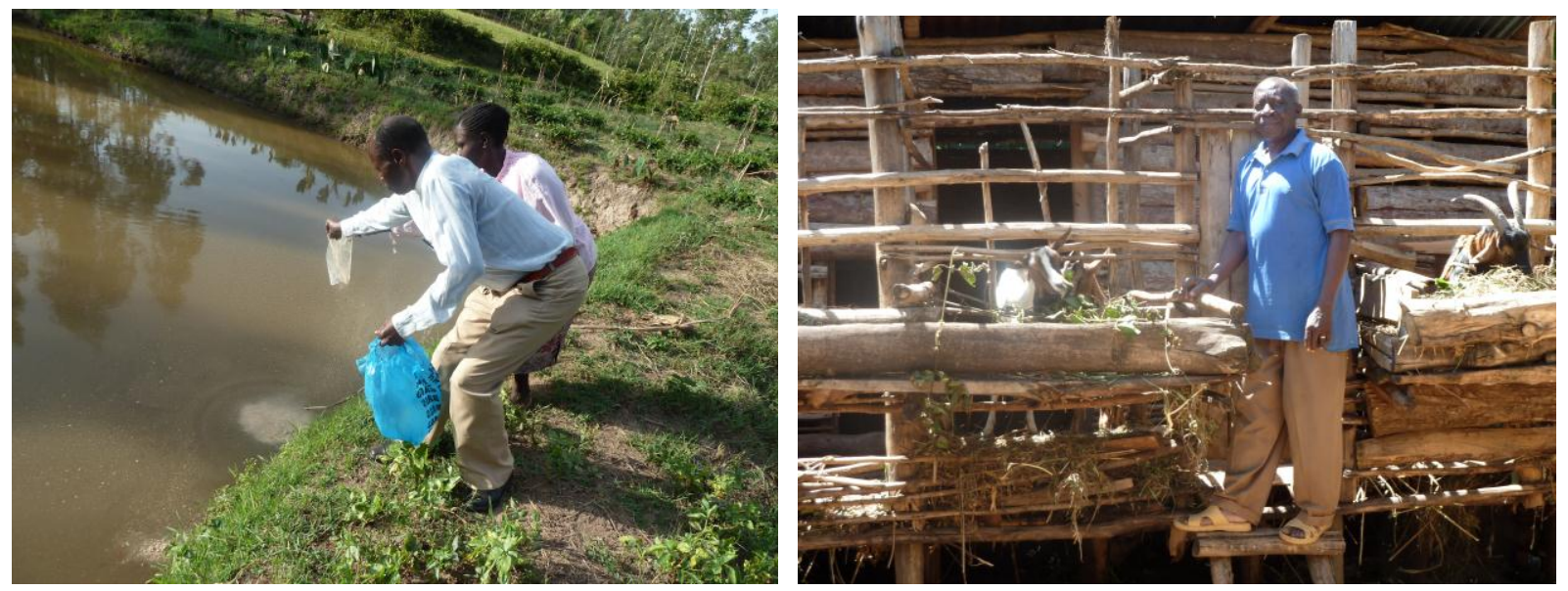

Figure 2.1: Fish Farming and Dairy Goat Keeping

Source: Author (March 2011)

Agricultural officers also expressed their frustration with the way some of the CDF projects were implemented and indicated that there was a lack of coordination between the different ministries and departments while designing and implementing these projects and their technical expertise was only sought after things were already out of hand:

Even when projects are implemented, this is done so poorly- there is no training and coordination among the relevant departments and the outcome is disastrous. For instance the MP for Vihiga wanted to introduce a new variety of ripening bananas in his constituency and so he got the tubers and they were distributed to farmers without any training and so some of the farmers were even cooking the tubers because they look like arrowroots. In other instances, grade chicks were distributed to self-help groups without any prior training on how to take care of them. It is when things started going wrong that they now decided to involve the extension officers but it was too late to salvage the chickens. So the initiative is there but the implementation is poor. Even in Hamisi, the same thing happened - agricultural officials were not involved in the implementation because some of these people want to take shortcuts. When they went to buy the seedlings for the bananas, they went to an infected farm and after the farmers planted them, they started turning yellow after a few days due to the BXW disease. So CDF has the money but they don't involve the ministry. (Peter Lodenyo, Vihiga District Crops Officer, 1/5/2011 - Personal Communication)

Since CDF projects are implemented at the Constituency level, different constituencies have focused on different projects as identified by their CDF committees. In Emuhaya Constituency, agriculture projects funded through this program included rehabilitation of cattle dips, construction of tea buying centers, poultry, bee keeping, dairy farming and horticulture 
projects. These projects were implemented through Women and Youth groups. By the 2009/2010 financial year, over Kshs. 18 million had been spent on these projects.

\subsection{Infrastructure Development}

According to the 1984 -1988 Kakamega DDP, roads in the district were in an appalling state of maintenance during in the early 1980s. The 1979- 83 development plan had proposed numerous projects that included repairing and improving the existing roads and the construction of new ones. Of the proposed projects, only $35 \%$ were completed due to financial constraints. In the 1989 - 1993 DDP it was specifically proposed that bitumen be put on five roads in the district to make them all weather in order to open up access to the rural trading centers to "stimulate production in all areas of the district". These proposals were partially implemented and by the time Vihiga District was created in 1991, the new district had a total road network of 554.1 kilometers of which 374.4 kilometers were classified ${ }^{2}$. The tarmacked roads in the district were parts of major highways linking major towns such as the Kisumu- Kakamega road, the LuandaMajengo road, Kisumu - Busia, Luanda - Siaya and the Chavakali - Kapsabet road. Most of the other roads were covered with gravel and earth and became impassable during the rainy season. By 1997, the total number of kilometers of classified roads had risen slightly to 400.5 kilometers from 374.4 kilometers in 1991. The 1994 - 96 DDP proposed making most of the roads in the district all weather with priority being given to the roads leading to high tea and coffee production areas of the district. High potential divisions of Vihiga, Tiriki and Sabatia were favored to benefit from better roads while Emuhaya division was left out. At the beginning of the $2002-2008$ planning period, the number of kilometers of classified roads had risen to 801 with $116 \mathrm{~km}$ covered in bitumen, $262 \mathrm{~km}$ covered with murram/gravel and the rest covered with earth.

Road maintenance remained a priority on the DDPs over the three decades even though lack of funds was a setback to the implementation of the proposed projects. This changed somewhat after the adoption of the CDF strategy when some of the available funds were allocated to these projects. Each of the four constituencies have benefitted substantially from CDF funding

\footnotetext{
${ }^{2}$ Roads in Kenya are classified as bitumenized, gravel and earth based on their surface type.
} 
of roads and bridges. The rationale for this trend has remained that well maintained infrastructure is a prerequisite for development as indicated by the parliamentary representative of Emuhaya Constituency:

It (CDF) has brought infrastructure which is development. If you want development, just do infrastructure, infrastructure, infrastructure..... the rest takes place. So infrastructure is in place. Healthcare - so many health centers, people are being treated. Health care is subsidized but the people also have to pay some money as a commitment. So there is healthcare, schools - we have renovated all the schools. So CDF has a direct impact to[sic] the household, to the individual, to the society. (Wilbur Ottichilo, Emuhaya Constituency MP, 12/29/2010 - Personal Communication)

Emuhaya Constituency CDF spent a total over Kshs. 37 million on improvement of roads and bridges between 2003 and 2010 (see Fig. 2.2). This included opening up of feeder roads, grading, graveling and installing culverts to increase access to public institutions such as schools, markets, health facilities and the movement of agricultural produce to markets. Other constituencies in the County also allocated their CDF funds to similar road improvement and bridges. At the beginning of the 2008 planning period, Vihiga district (2007) had a total of $135 \mathrm{~km}$ of the roads covered in bitumen, $212 \mathrm{~km}$ covered in gravel/murram and $315 \mathrm{~km}$ covered in earth. When asked about how important the roads projects were to them, $57.5 \%$ of the study sample indicated that roads were very important while $38.3 \%$ stated that they were important with only $2.08 \%$ stating that they were not important at all.

In 2009, maintenance of rural access roads at the national level also benefitted from the Kazi Kwa Vijana (KKV) (Jobs for Youth) program initiated through the Office of the Prime Minister. The goal of the KKV program was to employ between 200,000 and 300, 000 youth in labor intensive projects that included building water dams, clearing bushes, planting trees and repairing rural access roads (Fig. 2.2). The project was a component of Kenya Youth Empowerment Project funded by the World Bank. However, the World Bank withdrew its support in 2011 citing fraud and misappropriation of project funds. 


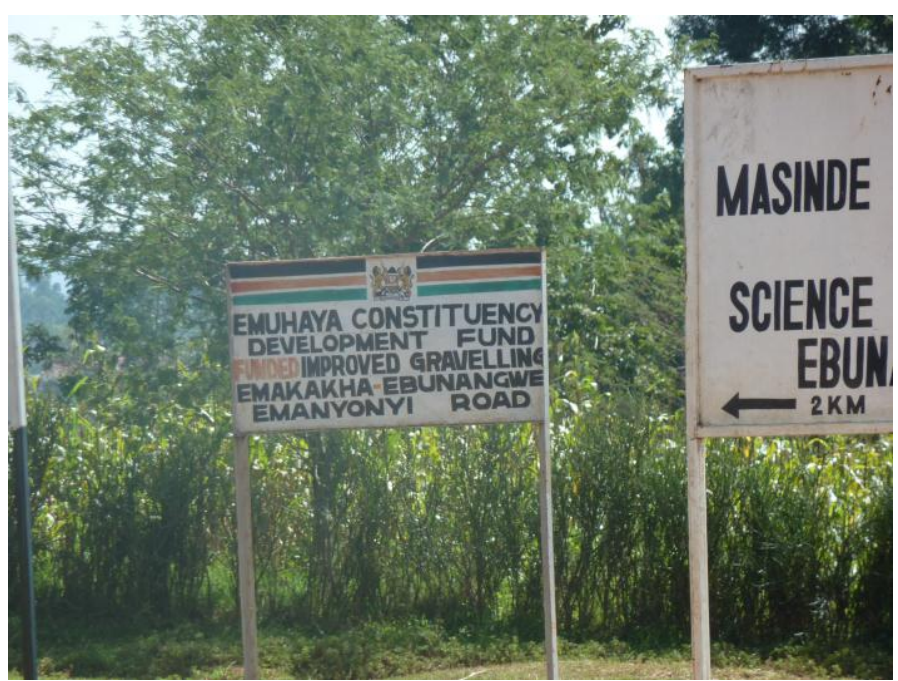

Figure 2.2: A sign for one of the Emuhaya CDF sponsored rural access roads

Source: Author (March 2011)

The telecommunications sub-sector has also shown significant changes over the past three decades and especially after Vihiga District was created in 1991. The 1994-96 DDP proposed projects focused mainly of extending postal services to a wider population and $66 \%$ of the proposed projects were implemented. In 1997, the number of post offices and sub - post offices had risen to 16 and 9 respectively while the whole district had a total of 54 public telephone booths that were unevenly distributed in the district with Vihiga Division having the most at 24 and Emuhaya having only two. By 2002, the number of households in the District with phone connections in their homes was 282 while the total number of public phone booths had gone down to 48. This period also saw the beginning of the influx of cell phone technology in rural areas in Kenya with Vihiga having $30 \%$ coverage. Of the 240 households that were surveyed for this study in 2011 , over $75 \%$ had at least one cellphone.

The rural electrification programs initiated in the 1980s succeeded in supplying electricity to most of the major trading centers in the district even though the distribution was also quite uneven with Sabatia and Vihiga divisions having a wider coverage than Emuhaya and Luanda divisions. It was hoped that the availability of electricity at local market centers would stimulate growth in industrial and commercial investments especially in the informal jua kali sector and thereby addressing the theme of the 1997 - 2001 DDP, Rapid Industrialization for Sustainable 
Development. Proposals were also made to supply some of the boarding schools and health facilities with electricity during the $1997-2001$ plan period. At the beginning of the 2002-2008 planning period, a total of 2400 homes and 41 trading centers in the district were connected to the electric grid. The implementation of rural electrification projects under the CDF during this planning phase saw a significant rise in the number of institutions connected to the grid with more households taking advantage of the ease of access to have their homes connected as well. By the beginning of the 2008-12 planning period, $8.3 \%$ of all the households in the newly formed Emuhaya district and over 2000 households in Vihiga district (2007) were using electricity for lighting. However, the cost of installation remains prohibitive for most households in the district despite of the efforts of the rural electrification programs. Of the 240 households surveyed for this study in 2011, only 17 households (7.08\%) used electricity to light their homes.

In the education sector, the newly created Vihiga district in 1991 had 4 pre-primary schools, 332 primary schools, 72 secondary schools, 12 youth polytechnics for vocational training and one teacher training college. These institutions were poorly equipped and lacked basic facilities like classrooms, laboratories and workshops and since government funds for providing such facilities was barely forthcoming, most of the schools relied on Parent-Teacher Associations and public fund-raisings to raise money to build these facilities. The cost of education, especially at the secondary school level, remained prohibitive for many households leading to high drop-out rates. One of the proposals for the 2002-2008 DDP was to provide bursaries for needy students to attend secondary school. CDF Committees in all the four constituencies in the County allocated substantial amounts of money towards improving the schools and provide bursaries for needy students. In Emuhaya Constituency, more than Kshs. 77 million was spent on education between 2003 and 2010 to construct classrooms, science labs and libraries for primary and secondary schools as well as constructing workshops and provision of equipment for youth polytechnics. Over $78 \%$ of the households sampled for this study acknowledged that improving schools is very important to them. However, the number of public educational institutions in the county does not meet the prevailing need and this has resulted in the mushrooming of private schools and colleges across the county.

Like the other infrastructure, the health sector has also recorded remarkable progress in recent past. In 1995, the district had a total of 30 health facilities with two main hospitals, 
Kaimosi and Kima, that were privately owned and a district hospital under construction at Mbale, the designated district headquarters. The rest were government run health centers and private clinics spread across the district. Most of these health centers were renovated during the $1994-$ 1996 and the 1997 - 2001 planning periods. The main setback in this sector has been the lack of qualified personnel, equipment and supplies. At the beginning of the $2002-08$ planning phase, the district had a total of 57 private clinics, 3 hospitals and 20 health centers with a doctor/patient ratio of 1:50,000. With the district split up in 2007, the new Vihiga district had two hospitals, 8 health centers, 6 dispensaries and 10 private clinics with a doctor/population ratio of 1: 44,249. In Emuhaya Constituency, over Kshs 17 million was allocated to the improvement of the health facilities which included constructing maternity wings in three of the existing dispensaries and renovation of four others. By the beginning of 2008, Emuhaya had 2 hospitals, one private nursing home, four health centers and 11 private clinics with a doctor to population ratio of 1 : 41,585 . Over $76 \%$ of the sample studied acknowledged that improvement of health facilities was important to them. This was echoed by one of the local administrators who indicated that:

Within the past 7 to 8 years, there has been a great deal of improvement in terms of handling the medical facilities. When Moi left government, our health facilities had become dry but now if you walk around you will find health facilities with drugs etc. Another thing along those lines is the employment of manpower in medical facilities has been boosted - especially here at Esiarambatsi health center our staff levels have been boosted. There are times when we used to have only two nurses but now we have about six. We have a clinical officer, a laboratory technologist, we also have nurses under the CDF (Economic Stimulus?) project and so it is a positive approach. (Chief David Onyino - Echichibulu Location, 1/26/2011 - Personal Communication)

Directly linked to the health is the issue of access to potable water for domestic use. Availability of safe water for households in the county remains a problem and only $15 \%$ of the households surveyed for this study had access to piped and treated water with over $70 \%$ relying on untreated water from local springs (Fig. 2.3). When Vihiga district was created in 1991, it had six water treatment plants but the capacity of these plants was by far below the needs of the population. It was proposed in the 1997- 2001 plan that boreholes be sunk in strategic sites across the district to supplement the water supplied by the treatment plants. The $2002-2008$ DDP indicated that only 12,000 households in the entire district had access to piped water. The district had a total of 200 protected springs and 50 wells that provided water for domestic use while a total of 99,188 households had roof catchments for collecting rain water. By the 
beginning of 2008 - 2012 planning period, the new Vihiga district (2007) had 380 functional protected springs while 4200 households had access to a potable water point. On average, household members spent a half an hour to for every trip they take to collect water for domestic use. This time is even much longer during the dry months of January through March when most of the springs have very little water and filling up one 20-liter container takes longer than usual.
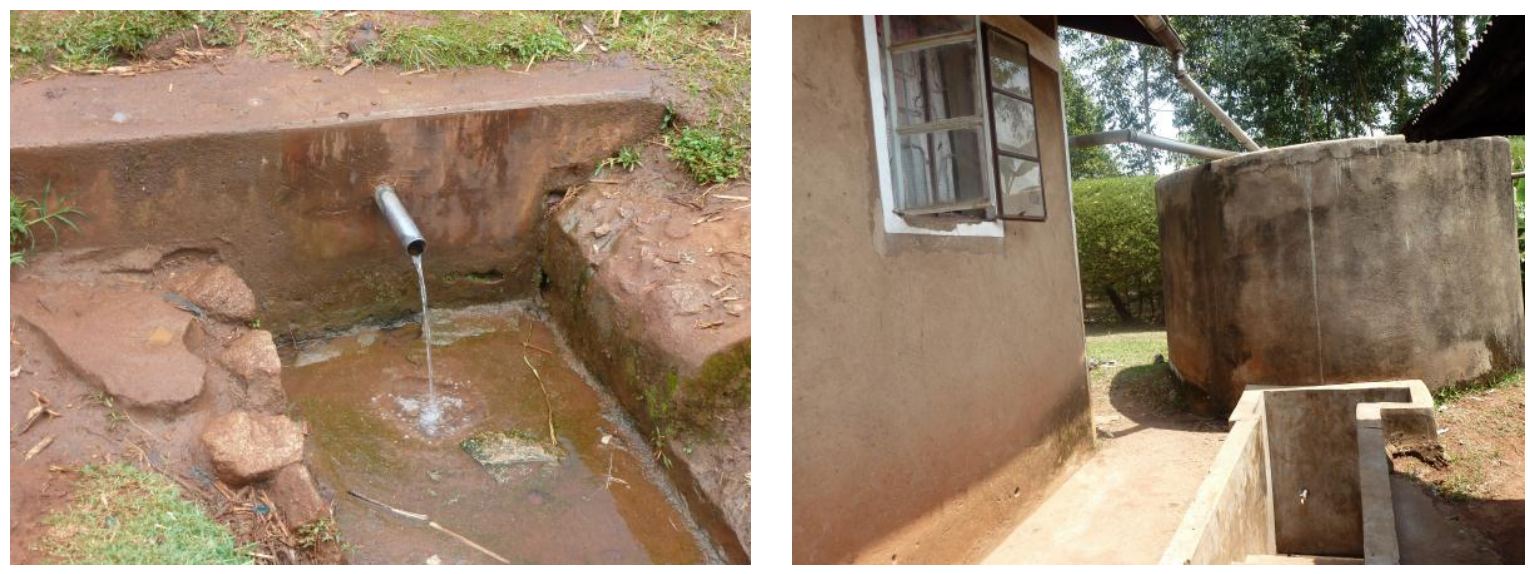

Figure 2.3: Domestic water sources that include springs (on left) and rain water harvesting Source: Author (March 2011)

\subsection{Urbanization, Commerce and Industry}

In 1978, the current area that makes up Vihiga County had four urban centers that included Luanda, Vihiga, Majengo and Kaimosi as well as numerous market places and rural centers. These centers have continued to expand in various ways in spite of the limited available space. In the 1984-88 DDP for Kakamega district, it was proposed that acquisition of land for further expansion of the then Vihiga Urban Council be prioritized alongside improving the markets in the area. The Council proposed that residential houses be built at Mbale and Majengo to house the staff working in these areas. The rapid urbanization of the area was seen as a positive trend that was to be encouraged by "providing social infrastructure as well as finance to spur greater economic activity in the hinterlands" (Kakamega DDP 1989 - 93, p.16). This approach, which was reflected in the District Focus for Rural Development Strategy, was part of the strategy to address the rural-urban balance. It was expected that viable market centers would attract capital for small scale industries that would have a positive impact on the agricultural 
sector and also serve as a source of revenue for the County Council. These centers were seen as ideal spaces for accumulation of capital as reflected in the 1989 - 93 Kakamega DDP:

In order to strengthen most of the market centers as rural trade and production centers, there is need to intensify provision of saving and credit facilities through postal and banking facilities (which are presently lacking from most of these centers). This will mobilize the local capital accumulation and increase investment in the District. (Kakamega DDP 1989 - 93, p. 19)

When Vihiga District was created in 1991, Mbale center was designated as its headquarters. However, there was no available public land on which to build the new offices and so some of the households around the center had to be relocated in order to create room for the new buildings. The creation of the new district saw a significant increase in licensed commercial activities that included maize milling (posho mills), sale of general merchandise (dukas), vehicle repairs, welding, furniture making and sale of second hand clothes. Among the objectives of the first Vihiga District DDP (1994 - 96) was the need to "provide a conducive environment for the establishment of industries which can use local raw materials and generate employment for the local people" (p. 46). To meet this objective, a tea processing factory and a maize milling plant were proposed. Proposals were also made to improve the local markets in the district.
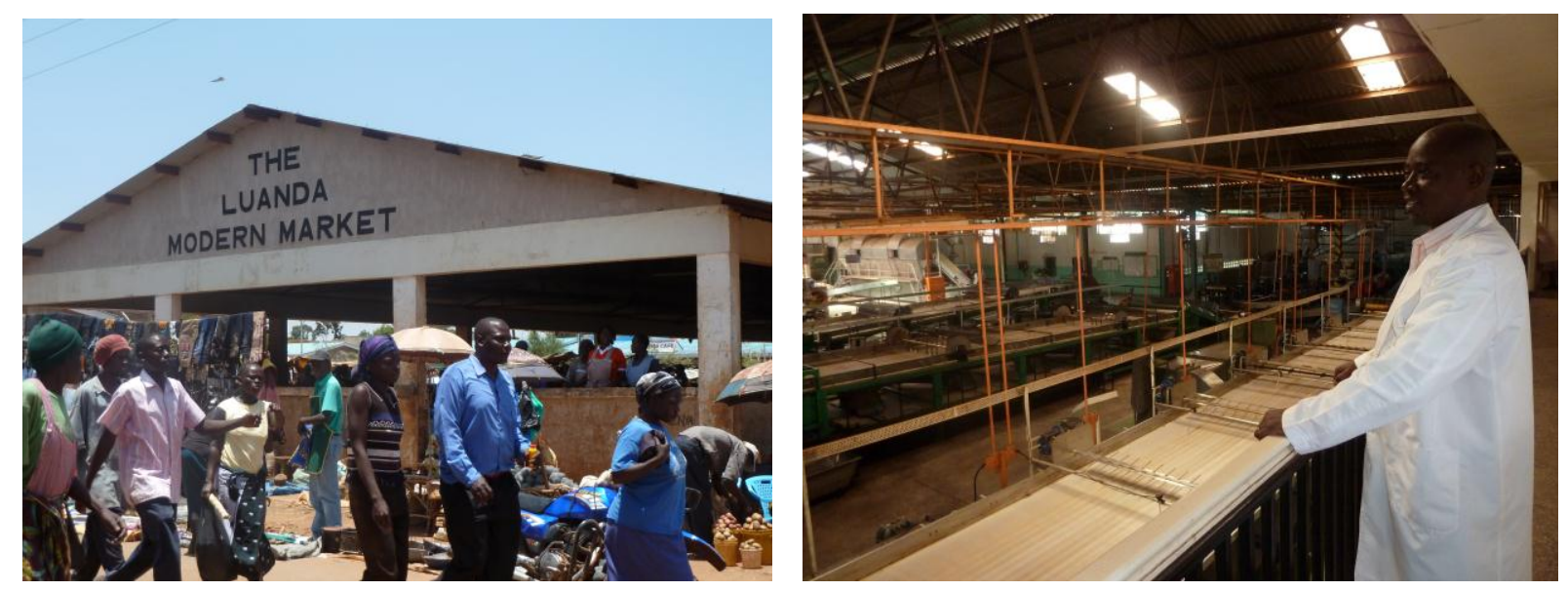

Figure 2.4: The Luanda "Modern" Market and inside the Mudete Tea factory

Source: Author (March 2011)

The 1996 Vihiga District Annual report indicated that there were more than 10 main trading centers in the district while the number of licensed businesses was on the rise even though the Kenya National Trading Corporation (KNTC) distributors who had monopolized the 
distribution of sugar were disbanded as part of the process of liberalization. Petty trading was the most popular commercial activity in the district with the number of traders increasing from 1365 in 1994 to 1404 in 1995. The district had 5 small scale "industries" specializing in making bricks and tiles, furniture and pawpaw juice/jam. The 1997 - 2001 DDP proposed several projects including a French beans canning factory, a milk processing plant and an ice-cream and yogurt plant in Vihiga Division and a stone crushing plant for Luanda and Emuhaya Divisions. It was noted that many potential entrepreneurs were faced with many challenges including lack of capital to invest in technology and inadequate training and perhaps availability of loans with flexible terms and interest rates would make a difference. Two commercial banks and two microfinance institutions with branches in the district were the targeted potential lenders.

At the beginning of 2002, the number of main trading centers had grown significantly to 50 while the number of licensed businesses and informal sector enterprises were 1443 and 3000 respectively. The number of financial institutions had also gone up to 5 while micro-finance institutions were 3. In order to ease the process of acquiring loans, the Department of Lands proposed mass issuance of title deeds to farmers in the district who could use them as collateral when applying for loans. Women were to be targeted for training in technical and management skills while the government was to set up a revolving fund to provide loans to potential entrepreneurs. These proposals were overtaken by the CDF projects which became the focus of development from 2003 onwards. Projects targeting to improve the infrastructure such as roads and rural electrification program were expected to have a significant impact on trade and commerce. The 2009 ESP program also specifically targeted the commercial activities and the informal sector by sponsoring the construction of fresh produce stalls and jua kali sheds at local market centers.

\section{Discussion}

This analysis points to two defining political economic moments in Kenya's recent history that have shaped the country's development trajectory in the neoliberal era. The first moment identified is the period in the late 1980s and early 1990s when the government was under pressure to adopt neoliberal economic policies. Prior to this moment, the Kenyan government had 
adopted a typical state-led development approach. The reluctance by the Moi administration to implement neoliberal economic policies at the rate and scale that the IFIs wanted meant that the government maintained, to some extent, a sense of control over the development agenda, an issue that remained contentious. In aggregate terms, Kenya's economic growth during this period was very poor and most of the projects proposed for implementation at the District level could not be implemented due to lack of capital. However, the few projects that were implemented like the livestock project in Vihiga were successful largely due to the support provided by the state. This support included availing the inputs like seeds and fertilizers as well as the technical support provided by agricultural extension officers and other state employees. Although there were efforts made then to encourage some of the farmers to venture into production for the market, the main policy emphasis was to improve the production for subsistence.

By the mid-1990s, the stalemate between Moi's government and the IMF and World Bank and the subsequent withholding of donor funds saw significant scaling back of state support as the NGOs became the conduit for funding development projects. Unlike state support that has continuity, support from NGOs is often haphazard, short-lived and limited to smaller scales. Consequently, projects that that were funded by NGOs could not adequately replace the gap left by shrinking state support. Laird (2007) had similar findings in Ghana where adoption of neoliberal policies led to a "deterioration of institutional capacity within the state sector" (p. 469). During this period, the emphasis in policy documents shifted from improving production for subsistence to encouraging farmers to produce for the market.

The persistent efforts by agricultural extension officers in the 1980s and 1990s for farmers to abandon keeping Zebu cattle in favor of imported dairy cows can be viewed capitalism's strategy of destroying indigenous forms of production and reproduction. Although exotic breeds yield higher quantities of milk, they also require more capital investment in terms of care and treatment and as observed by area residents easily succumb to East Coast Fever unlike the local Zebu breeds. The introduction of exotic breeds of livestock, while at the same time cutting down on agricultural extension services forces farmers to rely more on private veterinary services which is expensive and often unaffordable for the average household. Consequently, only very few well-to-do households can afford to keep dairy livestock. 
The second defining moment was the ushering in of the new government in 2003, when the state fully embraced and implemented neoliberal policies in a bid to gain donor confidence. The resumption of donor aid saw the economy grow at impressive rates and was only interrupted by the post-election violence of December 2007 - January 2008. Significant changes occurred in the infrastructure sub-sector with the improved road network increasing access to previously inaccessible parts of the County while the construction of better school buildings and health facilities enhance the provision of this education and healthcare in the area. The agricultural subsector as well as the commerce and trade sub-sectors also showed some changes as the new government embarked on full scale implementation neoliberal policies.

A number of observed changes conform to what Harvey defines as forms of privatization. For instance, in the agricultural sub-sector, the withdrawal of government subsidies on farm inputs implies that only rich farmers can afford to buy certified seeds and use inorganic fertilizer on their farms. Given the level of soil exhaustion in the area due to repeated cultivation, the inability to access such inputs has significant repercussions on the farm output and subsequent household food security as shown in Chapter 3. Since the County is a net importer of maize and other basic foodstuffs, the privatization of the NCPB, a public state run institution, implies that the price of maize, which is the staple food in this area, fluctuates significantly. Maize trading and transportation is now dominated by unscrupulous cartels who release it to the market on their own terms. The implications of this trend on the food security of the majority of Vihiga residents who rely on the market for their maize supply are enormous.

The emphasis on switching to horticultural production rather than enhance maize production only exacerbates household vulnerability since any meaningful venture into horticulture requires intensive use of inputs which are already out of reach for most farmers while corrupt deals by government officials further marginalize the poorest households. This is further compounded by lack of access to agricultural extension services as discussed in Chapter 3.

The privatization in July 2000 of the KTDA, a parastatal in charge of production and marketing of tea, had far reaching implications for tea farmers in the County. As part of the process, the repayment of the loan that was procured for building the local tea factory at Mudete was passed on to unsuspecting tea farmers as part of "cost-sharing". As a result, the payments 
that farmers receive per kilogram of tea delivered to the factory declined since part of it was deducted for loan repayment. Even then, the viability/profitability of tea farming for a majority of the households in the County remains questionable as discussed in Chapter 3. Majority of the tea farmers have less than one acre of tea which is below the factory recommended acreage for optimum economic returns. Most of them do not keep any records of how much they spent on inputs and labor and so they cannot tell whether they are making any profits or not. However, farmers with larger farms are likely to get higher returns compared to those with smaller farms who might even be incurring losses. Furthermore since most of the tea is exported, its price depends on global market forces making the farmers even more vulnerable. Bush (2008) argues that such production systems are consumer driven and often it is "the retailer who exerts the power and where islands of capitalist agriculture exacerbate inequality" (p. 40).

Issuance of title deeds to enable farmers take loans with their land as collateral can also be read as part of the broader process of commodification of nature and a precursor to accumulation by dispossession (Harvey 2006, 2010). Although initial official land reform that entailed land registration was first conducted in this area in the 1960s (under the Swynnerton Plan), most households still do not have title deeds for the land they inherited from their parents. While having a title deed provides land owners with the security of tenure, it also signifies the commodification and alienability that makes it possible to transfer ownership. That explains why some landowners are reluctant to take bank loans that require them to use their title deeds as collateral as they risk losing the land should they fail to repay the loan.

Similar commodification processes are evident in the government "protection" of forest reserves where residents of Shaviringa location bordering the Kibiri Forest have to pay for permits to access forest products and in the state-sanctioned clearing of the Maragoli forest in the 1990s as discussed in Chapter 4. Although the households around Kibiri forest do not have access to the forest (except through illegal means or purchased permits), the state rents out portions of the forest to private companies to plant exotic trees or conduct research to generate revenue for the government.

The influx of lending institutions in the County is part of the process of financialization as farmers are encouraged to take loans to invest in their farms or businesses. This is also evident 
in the accelerated rate of money transfer made possible through the use of cell phones -MPESA. $\mathrm{CDF}$ projects have been played a central role in opening up the previously inaccessible parts of the County to allow easier movement. But with little actual production going on, much of this opening up has worked to the advantage of merchants and traders who are interested in the potential market for their products. However, the provision of health and education services in the County as public goods also serves to improve the quality of "labor reserve" in the County to improve their skills in preparation for work in nearby towns. Government funded projects can also be seen as elements of state redistributions with the tenders for the projects being awarded to the rich and powerful.

Overall, the changes that have taken place in Vihiga reflect the changing role of the state from fostering national development to enhancing integration into the global economy. By financing projects that improve infrastructure is facilitating the faster integration of Vihiga into the global economy by "expediting and arbitrating the stable expansion of capitalism" (Smith 2008).

\section{Conclusion and Policy Implications}

The state in Africa has a critical role to play in shaping the rural change and development trajectory. The findings presented in this chapter show how this role has evolved over the past several decades in post independent Kenya. In the decades following independence, the state adopted a proactive role in initiating, pursuing and funding development programs through different departments. However, with the adoption of neoliberal economic policies in the 1990s, the role of the state changed from being at the forefront of the development agenda to taking a back stage of providing an enabling environment for private enterprises to initiate and implement the development agenda. The implications of this approach here is exacerbated uneven development and increased vulnerability for rural households to both economic and environmental perturbations. More recent attempts by the state through programs such as the Constituency Development Fund are aimed at addressing the inequalities and socio-economic issues that arose as a result of the adoption of neoliberal economic policies. 
In the face of rising socio-economic problems such as escalating youth unemployment and inability to access higher levels of education due to poverty, the government has had to come up with stop gap measures to avert a complete breakdown in social order. Already crime rates in most urban areas are at an all-time high (Standard Newspaper July 18, 2012) and so have petty thefts in rural areas such as Vihiga. Kenyans still expect the government to take more proactive measures such as the Price Control Act 2011 to ease the economic strain that many Kenyans are experiencing. This kind of proactive reaction by the state is what Peters (2006) refers to as coming "full circle to the more sensible "structuralist" and "gradualist" approaches of the earlyto mid-1990s" (p. 342)

Yet such measures that are aimed at reducing the impact of neoliberal economic policies on vulnerable Kenyans cannot make much of a difference if little is done to address the underlying processes that cause vulnerability. While President Kibaki should be lauded for reintroducing a contentious policy that goes against the logic of neoliberal economics, a more meaningful overhaul of the country's economic development policy is necessary to arrest the downward spiral in the livelihoods of many rural (and urban) households. Perhaps the current volatile global economy might give impetus to such a move. Unfortunately, the nature of global economic connectedness means that Kenya may not be able to single-handedly revert to state led development policies without risking isolation. It is worth noting though that countries like Malawi have also taken similar steps to counteract the negative effects of neoliberal economic policies on the poor (Peters 2006).

\section{References}

Ayers A. 2006. Demystifying Democratization: the global constitutions of neoliberal polities in Africa. Third World Quarterly 27 (2): 321 - 388.

Bagaka, O. 2008,. Fiscal Decentralization in Kenya: The Constituency Development Fund and the Growth of Government. In Proceedings of 20th Annual Conference of the Association for Budgeting and Financial Management, October 2008, Chicago.

Barkan J. \& Chege M. 1989. Decentralizing the State: District Focus and the Politics of Reallocation in Kenya, The Journal of Modern African Studies 27 (3): 431 - 453. 
Bond P. 2006. Global Governance Campaigning and MDGs: From top down to bottom up antipoverty work. Third World Quarterly 27 (2): 339 - 354.

Bush R. 2008. Africa and Globalization, Soundings 36: 32 - 43.

Cline-Cole R. \& Harrison G. 2010. It is always the Political Economy Stupid. Review of African Political Economy 37 (126): 395 - 402.

Emuhaya District Development Plan 2008 - 2012

Ferguson J. 2006. Global Shadows: Africa in the Neoliberal World Order. Duke University Press, Durham NC.

Harvey D. 2003. The New Imperialism. Oxford University Press, Oxford.

Harvey D. 2006. Neo-liberalism as Creative Destruction. Geografiska Annaler 88B (2): 145 158.

Harvey D. 2010. The Enigma of Capital: and the Crises of Capitalism. Oxford University Press, USA

Hyden G. 1980. Beyond Ujamaa in Tanzania: Underdevelopment and an uncaptured peasantry. University of California Press, CA

Karugia J., Wambugu S. \& Oluoch-Kosura W. 2003. The Role of Infrastructure and Government Policies in Determining the Efficiency of Kenya's Maize Marketing System in Post-Liberalization Era. A Research Report Submitted to the International Food Policy Research Institute (IFPRI) 2020 Vision Network for East Africa

Kimenyi, M. S. 2005. Efficiency and Efficacy of Kenya's Constituency Development Fund: Theory and Evidence. Economics Working Papers, 200542.

Laird S. 2007. Rolling back the African State: Implications for Social Development in Ghana. Social Policy and Administration 41 (5): 465- 486.

Mahao N. 2009. Neoliberalism and the decline of the State: Can the Obama phenomenon contribute reinvigorating constitution democracy? International Journal of African Renaissance Studies 4 (1): 69 - 79.

Moore D. 2004. The Second Age of the Third World: from Primitive accumulation to global public goods. Third World Quarterly, 25 (1): 87 - 109.

Moseley W., Carney J., \& Becker L. 2011. Neoliberal Policy, rural livelihoods and urban food security in West Africa: A comparative study of the Gambia, Cote d'Ivoire and Mali, Proceedings of the National Academy of Sciences 107 (13): 5774 - 5779. 
Mosley P. 1986. The Politics of Economic Liberalization: USAID and the World Bank in Kenya, 1980 - 1984. African Affairs 85 (338): 107 - 119.

Peters P. 2006. Rural Income and Poverty in a time of Radical Change in Malawi, Journal of Development Studies 42 (2): 322 - 345.

Republic of Kenya 2007. Revised CDF Act 2007. Government Printer, Nairobi

Republic of Kenya 2005. Strategy for Revitalizing Agriculture 2004 - 2014. Government Printer, Nairobi.

Republic of Kenya 1989. National Development Plan 1989 - 1993. Government Printer, Nairobi.

Republic of Kenya 2008. Vision 2030, Government Printer, Nairobi.

Republic of Kenya 2011. Kenya Gazette Supplement No. 121. Government Printer, Nairobi.

Republic of Kenya 1986. Sessional Paper No. 1 of 1986 on Economic Management for Renewed Growth. Government Printer, Nairobi.

Republic of Kenya 2003. Economic Recovery Strategy for Wealth and Employment Creation 2003 -2007. Government Printer, Nairobi

Republic of Kenya 1995. National Development 1994 - 1996. Government Printer. Nairobi

Republic of Kenya 1990. National Development Plan 1989 - 1993. Government Printer, Nairobi

Republic of Kenya 1985. Kakamega District Development Plan 1984 - 1988. Government Printer, Nairobi

Republic of Kenya 1990. Kakamega District Development Plan 1989 - 1993. Government Printer, Nairobi.

Republic of Kenya 1995. Vihiga District Development Plan 1994 - 1996. Government Printer Nairobi

Republic of Kenya 1998. Vihiga District Development Plan 1997 - 2001. Government Printer, Nairobi

Republic of Kenya 2003. Vihiga District Development Plan 2002 - 2008. Government Printer, Nariobi

Republic of Kenya 2009. Vihiga District Development Plan 2008 - 2012. Government Printer, Nairobi 
Republic of Kenya 2009. Emuhaya District Development Plan 2008 - 2012. Government Printer, Nairobi

Republic of Kenya, 2007. Sessional Paper No. 1 of 2007 on Forest Policy, Government Printer Nairobi

Rowden R. 2010. Poverty Reduction is not Development. Review of African Political Economy 37 (126): $503-516$.

Shiverenje H. 2005. What happened to the PRSP in Kenya? The role of Politics, in IIED:

Participatory Learning: Civil Society and Poverty Reduction, www.pubs.iied.org last accessed on Dec 282012.

Smith N. 2008. Uneven Development: Nature, Capital and Production of Space. The University of Georgia Press, Athens, GA.

Spieß C. 2004 "Betwixt and Between": The South African State's Search for Autonomy in the Face of Globalization. Commonwealth and Comparative Politics 42 (1): 129 - 155.

Standard Newspaper Digital, July 18, 2012. Do Something about rising crime in Nairobi. http://www.standardmedia.co.ke/?articleID=2000062090\&story_title=Do-something-aboutrising-crime-in-Nairobi last accessed on March 302013

Swallow B. 2004. Potential for Poverty Reduction Strategies to Address Community Priorities: Case Study of Kenya, World Development 33 (2): 301 - 321.

The Institute for Social Accountability (TISA), http://www.tisa.or.ke/about-devolvedfunds/constituency-development-fund/ last accessed on Dec 102012.

World Bank 1994. Memorandum of the President of the International Development Association to the Executive Directors on a Country Assistance Strategy of the World Bank Group for the Republic of Kenya

World Bank 1996. Memorandum of the President of the International Development Association to the Executive Directors on a Country Assistance Strategy of the World Bank Group for the Republic of Kenya, January 2, 1996. Report No. 15254 - KE

World Bank 2004. Memorandum of the President of the International Development Association and the International Finance Corporation to the Executive Directors on a Country Assistance Strategy for the Republic of Kenya, May 19, 2004. Report No. 29038-KE

World Bank 2010. Kenya Joint IDA-IMF Staff Advisory Note on the First Medium Term Plan (2008 - 2012) for Kenya Vision 2030. Feb 18, 2010. Report No. 53124 - KE 
Watts M. 1989. The Agrarian Question in Africa: Debating the Crisis. Progress in Human Geography 13 (1): 1 - 42. 


\title{
Chapter 3
}

\section{"Living Like we are in the City": Changing Rural Livelihoods in a period of Rapid Economic Transition.}

\begin{abstract}
This study examines the livelihood activities of rural households in a rural County in western Kenya in the wake of neoliberal economic change. Using a mixed method approach the study examines the current livelihood options available for households and how these options have changed since Kenya's approach to development shifted from being state-led to being market-driven. The findings show that the adoption of neoliberal economic policies contributed to the shrinking of livelihood diversification options for many households that are already grappling with socio-cultural strains in the face of declining farm sizes. Many households have become poorer, cannot afford to educate their children and are chronically food insecure. In taking away their livelihood diversification options, neoliberal economic policies have made rural households more vulnerable to economic perturbations due to their heavy dependence on the market and to environmental perturbations such as erratic rainfall patterns.
\end{abstract}

\section{Introduction}

As a hegemonic ideology, neoliberalism has infiltrated all aspects of human life in every part of the world in both discursive and material ways. Harvey (2006) defines it as a "theory of political economic practices which proposes that human well-being can best be advanced by maximization of entrepreneurial freedoms within an institutional framework characterized by private property rights, individual liberty, free markets and free trade” (Harvey 2006, p.145) while Harrison Graham (2010) refers to it as a form of "social engineering". Neoliberalism is associated with the increased domination of the International Financial Institutions (IFIs) - the World Bank, International Monetary Fund (IMF) and the World Trade Organization (WTO) (or the "Unholy Trinity" as Peet (2003) refers to them) as well as multinational corporations (MNCs). Within this ideological framework, state- initiated interventions and policies are viewed as a hindrance to development as they are "the antithesis of smooth functioning of markets" (Watts 1989, p. 7). The impact of neoliberal policies on the lives of vulnerable populations around the world is a subject that often generates a passionate debate between its proponents who see it as 
the only viable route to development and critics who see it as perpetuating uneven development that enriches a few and impoverishes many.

The adoption of neoliberal economic policies in sub-Saharan African countries in the 1980s and 1990s as part implementation of the Washington Consensus called for an overhaul of development policies that focused on reducing the role of the state by promoting economic liberalization, deregulation, privatization and institutional reform. Proponents of neoliberalism insist that meaningful development can only take place when the role of the state is reduced and the free market creates opportunities for poverty reduction. Critics on the other hand argue that most African countries' economies are still fragile and the state is an important actor in protecting these economies (Oya 2007b, Kwadwo 2000). Studies indicate that the impact of these policies has varied across countries and socioeconomic groups. For most of the agricultural communities in rural Africa, neoliberal policies such as the removal of subsidies on agricultural inputs and consumer food prices, elimination and/or reform of parastatal marketing agencies and liberalization of agricultural prices have had a large effect on livelihood strategies at the household level (Kwadwo 2000, Oberhauser 2010, Harrison 2010, Bernstein 2004, Peters 2006). While such studies provide a general picture of the unfolding scenario, the heterogeneity of rural sub-Saharan Africa calls for more local level studies that can be used as a reference point in relating the discursive aspects of this dynamic to its material manifestation. This study seeks to contribute to this debate through an empirical and dialectical analysis of the livelihood activities rural households in a rural county in western Kenya over the past three decades of neoliberal reforms.

Dialectics is a way of thinking that has roots in the works of $19^{\text {th }}$ century philosophers such as Hegel, Kant and Fichte. It is based on the idea that everything that exists is in perpetual flux. Hegel's dialectics which suggests a change trajectory that proceeds in three stages that entail thesis, antithesis and synthesis has been criticized as being overly teleological. The analysis used in this study draws from Harvey's (1996) and Ollman's (2003) dialectics that is “much broader, open-ended, less totalizing, non-teleological” (Sheppard 2008, p. 2610). Ontologically, dialectics seeks to understand "processes, flows, fluxes and relations" as opposed to "elements, things, structures and organized systems" (Harvey 1996, p. 49) and in doing so, "brings into focus the full range of changes and interactions that occur in our world" (Ollman 
1993). Harvey further notes that in dialectical thinking, things that may otherwise appear stable or unproblematic are inherently contradictory because of the multiple processes or relations that constitute them and which make them heterogeneous. Consequently, attempts to understand these things needs to involve an understanding of the processes and relations that they are made of while also acknowledging that things only internalize that which is relevant to them (ibid) and hence "contradictions are a source of growth and discovery" (Mensah 2008, p. 37).

By focusing on the processes and relations of change, dialectics offers an insightful and more holistic way of examining the evolution of rural livelihoods within the broader global economic processes. The process of abstraction involved in dialectical analyses also makes a useful analytical tool in linking the discursive and the material dimensions of livelihood change. Following Mensah (2008), my adoption of dialectics to interrogate the livelihood experiences of rural households in a neoliberal economic regime is borne out of the acknowledgement that livelihoods are dialectical "in the sense that they are internally heterogeneous and contradictory, emanate from many different sources, exhibit a variety of forms and resist easy synthesis and categorization" (p. 35). A dialectical reading of livelihoods, whether rural or urban, therefore acknowledges their complex nature while viewing them as processes that are in constant flux and often, the diverse strategies that households may engage in may actually undermine their efforts to improve their livelihoods. This broader dialectics allows for multiple, overlapping and contradictory possibilities where cause and effect are interchangeable and in this case where economic change presents multiple opportunities and risks simultaneously (Bernstein 2004).

\section{The Nature of Africa's Rural Livelihoods}

Studies that analyze rural livelihoods in sub-Saharan Africa point out the fact that making a living on the countryside is becoming increasingly complex, requiring households to keep adjusting and engaging new strategies (e.g. Francis 2000, Bryceson et al. 2000, Ellis 2000, Peters 2006, Berry 1993, Bernstein 2004; Neves \& Du Toit 2013). Livelihood diversification is the term used to define the nature of this multi-dimensional way of life. Most rural households engage in a variety of agricultural and non-agricultural activities. While the origins of this transition can be traced in colonialism and subsequent incorporation into the global capitalist mode of production, 
there are indications that it has accelerated over the past several decades of neoliberal economic change. Several studies have highlighted the negative impact of neoliberal economic reforms on rural livelihoods. Bryceson et.al. (2000) argue that the "the implementation of structural adjustment policies and market liberalization worldwide have had a dissolving effect in peasant livelihoods." (p. 29). Similarly, Bond points out that despite the varying local dynamics, there are persisting indications of "relationships between deepening economic exploitation, neoliberal policies and social integration.... that can be traced to the global scale" (p. 20)

With most of the communities still relying on farming to some extent, neoliberal policies implemented in the agricultural sector have had the most impact on rural households. Such policies entailed measures to liberalize and deregulate markets and withdraw state support to farmers as discussed in Chapter 2. With farm inputs out of reach for most farmers, productivity of food and cash crops has fallen significantly. In the wake of increasingly difficult and complex conditions, households are now forced to engage in more diverse and often new strategies. Ellis (1998) defines diversification as the "process by which rural families construct a diverse portfolio of activities and social support capabilities in their struggle for survival and in order to improve their standards of living" (p. 4). Diversification can exacerbate already existing inequalities in that while poor households diversify for survival, richer households diversify to accumulate (Oya 2007, Lay et al. 2008, Ellis 1998, Bryceson 2000, Iiyama et al.2008). Furthermore, although diversification may enable households to have extra capital to invest on the farms, it can also potentially harm agriculture by withdrawing critical resources such as labor and land (Ellis 1998, Francis 2000).

The place of agriculture in rural livelihoods is becoming less central as the younger generation realize that they cannot make a living off it. Bryceson (2000) notes that the youth are cognizant of this fact and because many of them lack adequate formal education to seek for jobs away from home, many are now turning to "non-agricultural income diversification especially petty trade" (Bryceson 2000, p. 57). Oberhauser (2010) notes that such "shift(s) in economic strategies among households and communities is related to socio-spatial patterns that accompany an increasingly integrated global economy" (p. 222) 
As livelihoods become more diversified, rural households are becoming more heterogeneous in their composition, access to resources and capabilities. In their study of rural households in Kenya, Githinji and Cullenberg (2003) note that the households could be classified into 32 categories based on variables such as land ownership, labor and ownership of a non-farm enterprise. Households in themselves are a contradictory unit. Githinji and Cullenberg's (2003) study also shows how households are involved in different class sets and hence have complex relations between them. An example of this would be if a household has a farm on which they grow both cash and food crops while some of the members may also be engaged in nonagricultural income generating activities such as carpentry, masonry or petty trade.

The current situation in Africa's countryside is described by Bernstein (2007) as "a crisis of reproduction" marked by increasing differentiation between those who are able to farm and those who are unable to farm as a basis of reproduction, with mounting tension over land as a basis of livelihood. Contrary to persistent misconceptions perpetuated in policies on the agrarian nature of rural livelihoods, not everyone in Africa's countryside has access to land - there are those who are too poor to farm and have to depend on their own labor for reproduction. In some parts of the continent, many now belong to what Bernstein (2007) calls classes of labor and depend directly or indirectly on wage employment and various combinations of survival activities that may include some kind of farming. This has further been enhanced by commodification of land, labor and peasant farming in response to market demand. This process of semiproletarianisation has led to the creation of a class of rural poor that is "neither dispossessed of all other means of reproducing itself nor in possession of sufficient means to reproduce itself” (Githinji 2000, Bernstein 2007). Wage labor and remittances from migrant laborers are now more than ever important dimensions of rural livelihoods. Githinji (2000) argues that the heterogeneity that characterizes the composition of rural households requires that "class" be viewed as a process (dialectically) and not necessarily as a static category, so as to be able to discuss the "multiple and often contradictory class positions that rural households often occupy" (Githinji 2000, p. 165)

Although there is a general consensus within rural change literature on the negative effects of neoliberal economic reforms on rural livelihoods, local level studies that substantiate this narrative while demonstrating the global-local dialectic that takes into account the heterogeneity 
of rural Africa are still few. Such studies highlight the way local institutions and dynamics through which neoliberal policies are sifted make a tremendous difference in the experiences of rural communities. More recently, policies based on the post-Washington Consensus have taken the center stage in driving rural development in Africa. Sandbrook (2005) notes that this newer approach acknowledges the failure of the policies based on the Washington Consensus in addressing poverty. What remains to be seen is how this acknowledgement translates into policy.

The main objective of this study is to examine the ways in which livelihood activities of rural households in rural western Kenya had changed over the past two to three decades. While acknowledging that change in itself is inevitable, the underlying assumption in this study was that the broader ongoing economic change at the global, national and local levels presents a different environment in which rural households pursue their livelihood activities. It was anticipated that a new environment would present both challenges and opportunities for these households.

\section{Study Area}

Vihiga County is one of Kenya's 47 counties that were created in 2011 after the promulgation of the new constitution that introduced devolved government. The county is made up of four districts, namely Vihiga, Hamisi, Emuhaya and Sabatia. Prior to 2007, the four districts were divisions in the then Vihiga District. Hence, the boundaries of pre 2007 Vihiga District were retained in the creation of Vihiga County. Situated within the Lake Victoria basin, the county lies between longitudes $34^{\circ} 30^{\prime}$ and $35^{\circ} 0^{\prime}$ East and latitudes $0^{\circ}$ and $0^{\circ} 15^{\prime}$ North, with the equator passing across the southern tip and to the north of lake (Fig. 3.1). 

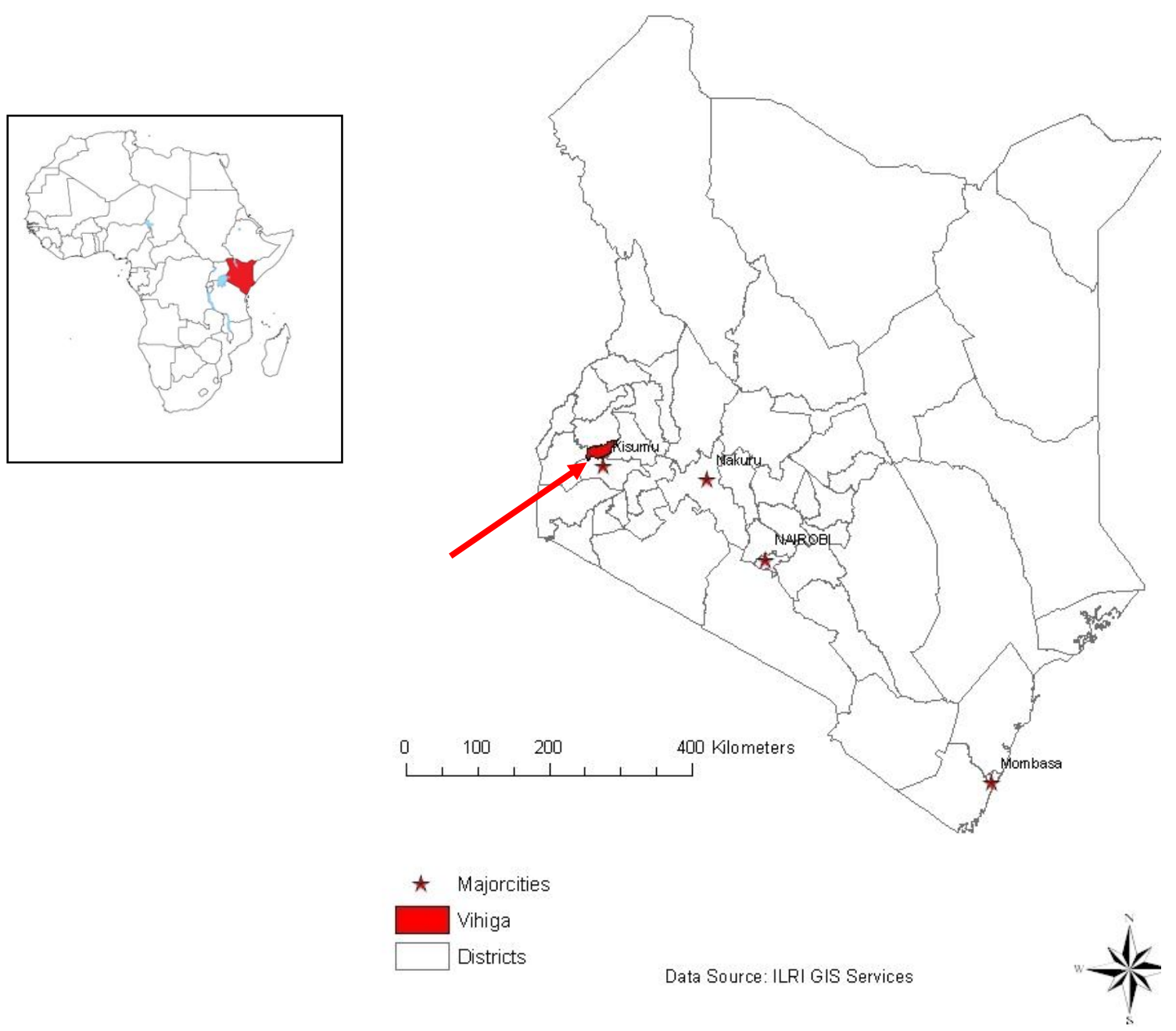

Figure 3.1: Location of Vihiga County, Kenya

By virtue of its location in the Lake Victoria basin, Vihiga falls in Kenya's high potential agricultural zone that has a fairly reliable rainfall regime. However, with over $60 \%$ of the population living below the poverty line and a population density that averages 1,200 per square kilometer, Vihiga has some of the highest spatial concentration of rural poverty in the country (Kristjanson et al. 2004, Conelly \& Chaiken 2000, Crowley \& Carter 2000, Place et al. 2007). The main land cover classes include small parcels of cultivated plots, forest cover (Kibiri forest in Shaviringa Location is the southern tip of the larger Kakamega forest) and the hilly and rocky terrain in the southern parts of the County. 
The genesis of livelihood sustainability decline in Vihiga can be traced back to early years of colonial expansion into the region. In Going their Separate Ways, Maxon (2003) gives a detailed account of the transformations that occurred in this area in the early decades of the 20th century as it became integrated into the global capitalist economy. According to Maxon, precolonial Vihiga had a typical moral economy where subsistence needs, surplus production and risk aversion influenced household decisions on productive and reproductive activities. Colonial expansion into the interior of east Africa and especially the building of the Uganda railway played a crucial role in defining the scope of transformations that were to take place here.

The proximity of Vihiga to the Uganda railway terminus in Kisumu provided the opportunity for Vihiga households to begin to participate in the market economy through producing maize for sale. Additional participation in the colonial capitalist economy was in the form of migrant labor as some of the men migrated to urban areas as wage laborers to supplement the dwindling farm income due to shrinking farm sizes (Maxon 2003, Francis \& Hoddinott 1993). Writing about the plight of Vihiga households in the 1940s, Maxon (2003) notes:

Conditions in Vihiga forced thousands, predominantly males, to leave the region to seek employment in cities and towns and on European settler farms as migrant workers. This pattern, which included not only those with little or no land, had been well established in the 1930s and indeed earlier. This trend, characteristic of semi-proletarian conditions, accelerated in the following decade, first as a consequence of the demands of the war (WWII), and later out of economic necessity. (p. 204)

As Vihiga became "captured" by capital, households were driven to diversify their productive and reproductive activities and the inevitable outcome was an emergence of a stratified society with a gap between those who were able to diversify for accumulation and those who had to diversify for survival. This situation was further compounded by lopsided state policies on rural development that were more favorable to the accumulators. The extent to which Vihiga had become incorporated into the global economy became pronounced during the period of the Great Depression when most of the migrant laborers returned home due to job losses and as market conditions became unfavorable due to the poor state of the economy. Households relying on the sale of maize and on remittances from the migrant laborers suffered a great deal. Furthermore, the approach of the state to this situation seemed to exacerbate the disintegration of Vihiga's 
economy and livelihoods. Having been captured by the global capitalist economy, Vihiga residents began to associate development with increased participation in the market economy through the production of high value cash crops like coffee. Initial requests made by local leaders to the colonial agricultural officials to allow farmers to grow coffee were denied due to what the state indicated as concerns over the dwindling land sizes. Eventually, the state allowed a few households who had over 7 acres of land to grow coffee. This new development presented another avenue for diversification for accumulation and reinforced the emerging process of class differentiation that now characterizes this region.

Needless to say, present day Vihiga is a highly differentiated society with a few households who are doing well economically while most are unable to even afford to eat three meals daily. Some of community leaders interviewed in this study seemed to blame the residents themselves for their plight, arguing that the young men in the County are too lazy and dependent on hand outs. There is an over-accumulation of labor in Vihiga and this is evident at market places and peri-urban centers where scores of able-bodied young men can be seen idling at shopping centers, bus stages and market places. While some are engaged in some form of activity such as scouting for passengers for minivans that transport people locally or transporting 'clients' on motorbikes and bicycles, many are just idling around not engaged in any form of productive work.

\subsection{Study Sites}

Fieldwork was conducted in three of the four districts in the County - Vihiga, Hamisi and Emuhaya. At the district level, locations were purposively selected to ensure a representative sample in terms of socio-economic dynamics and topographical features. The three locations selected were Echichibulu in Emuhaya District, Shaviringa in Hamisi Location and Mung'oma in Vihiga District (Fig. 3.2).

Emuhaya district covers an area of $173.2 \mathrm{~km}^{2}$ with an altitude range of 1350 and 1500 meters and an average population density of 1234 persons per square kilometer. Luanda town along the Kisumu-Busia highway is the main business hub in this district with smaller trading centers spread across the district. Households in Emuhaya engage in diverse income generating 
activities including agriculture and retail/wholesale trade. Main crops grown in the district include maize, finger millet, sorghum, cassava, sweet potatoes, beans, bananas and tea. Over $80 \%$ of the population obtains water for domestic use from springs in river valleys across the district and about $46 \%$ spent at least 5 minutes on every trip they make to collecting. A majority of the district residents have attained formal education only up to primary school. The commonly used fuel for lighting and cooking is paraffin and firewood respectively. Although most of the residents' houses are roofed with corrugated iron sheets, many of these houses have earthen flooring and mud and wood walls.

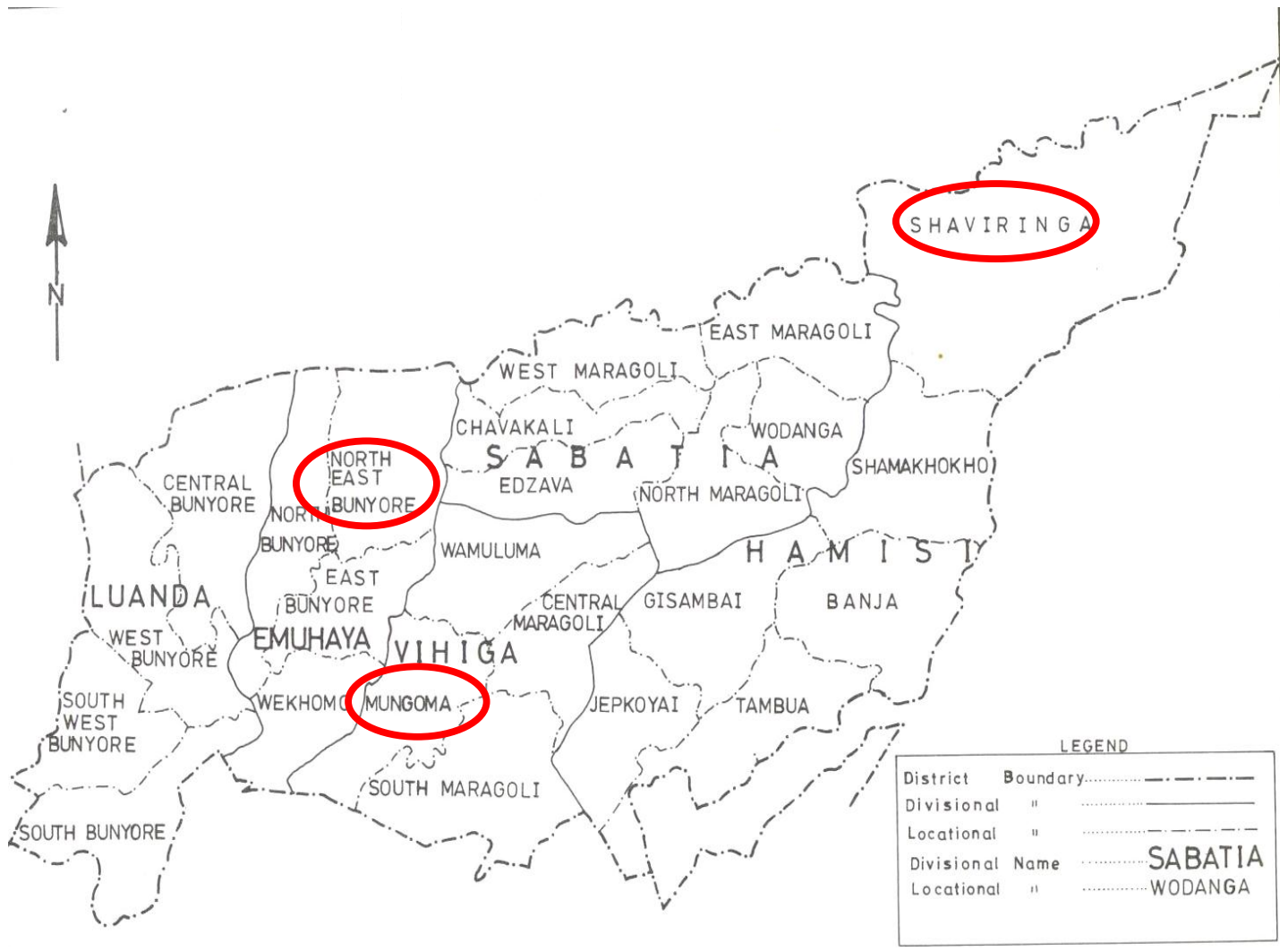

Figure 3.2: Vihiga County Administrative Locations

Source: Vihiga District Development Plan 1997 - 2001 
Located in north-eastern part of Emuhaya District, Echichibulu is one of the 16 locations that make up the District. It is further divided into three sub-locations of Emurembe, Ebusiloli and Ebunangwe, and the Banyore, a Luhyia sub-ethnic group, are the majority population. In terms of infrastructure, the location has one public health center at Esiarambatsi, numerous primary schools, one boys boarding secondary school at Ebunangwe and a mixed day secondary school at Ebusiloli. Plans to convert the boys boarding school into a constituent college for one of the national universities located in western Kenya are still underway in spite of the reluctance by the African Interior Church who is the sponsor of the school to relinquish its ownership to the government.

Vihiga District, which shares the county name is located in the southern part of the county with an altitude range of 1300 to 1800 meters. Covering an area of 90.3 square kilometers, it is also the smallest of the four districts in the county and home to the County administrative headquarters at Mbale town (formerly the Vihiga district headquarters until 2007). Other major trading centers include Majengo and Chavakali along the Kakamega-Kisumu highway. The residents of this district are predominantly the Maragoli sub-ethnic group. The higher altitude is in the hills to the south of the district overlooking Lake Victoria. The average population density is 1,273 persons per square kilometer with an average household size of 5 and an average household farm size of 0.35 hectares. The main food crops grown include maize, beans, sweet potatoes, vegetables and bananas while tea is the main cash crop. Like in Emuhaya, most of the houses are built with iron roofing, mud and wood walls and earthen flooring. Mung'oma location is in the southern part of the district and includes the undulating Maragoli hills that were covered by an exotic forest from mid 1950s to the late 1990s.

Hamisi is the largest district in the county covering an area of 189.1 square kilometers and is located on the eastern part of the County. This district is the home to both the Maragoli and the Tiriki sub-ethnic groups with the former inhabiting the south western part and the latter in the north eastern. The district has an average altitude of $1500 \mathrm{~m}$ and annual precipitation of $2000 \mathrm{~mm}$. The population density in Hamisi, especially in the north east, is the lowest in the County. Major peri-urban centers in the district include Jeptulu and Shamakhoko along the Chavakali - Eldoret road and Serem along the Shamakhokho - Gambogi road. 
Located on the north eastern tip of the Hamisi district and covering an area of 43 square kilometers, Shaviringa is the largest location in the district and the County, half of which is covered by the Kibiri forest which is the southern extension of Kakamega forest. The location has three sub-locations namely Cheptulu, Shiru and Makuchi.

\section{Methods}

Recent methodological analyses into the study of human-environment interactions emphasize the need to for a mixed method approach (e.g. Barnes 2009, Sui \& DeLyser 2012, Cheong et al. 2011, Zolnik 2009, Yeager \& Steiger 2013). Sui \& Delyser (2012) noted that this approach is a way of "engaging the multiple voices present in the sites and communities" ( $p$. 119). Mixed methods make it possible to "compare, triangulate and generate a more comprehensive picture" (Cheong et al. 2011, p. 12) and opens up possibilities for more in depth understanding of geographic phenomena (Yeager \& Steiger 2013). In this study, a mixed method approach that involved the use of quantitative and qualitative data was used. Data was collected and analyzed separately and integrated at the interpretive level.

\subsection{Data Collection}

In order to capture the various dimensions of livelihood change, both qualitative and quantitative data were collected. The primary and secondary data collected included:

i. 240 households surveys

ii. 3 focus groups

iii. 21 key informant interviews

iv. 34 household head interviews

v. Policy documents including Annual Agricultural Reports, District Development Plans \& National Development Plans

vi. Rainfall data from two meteorological stations close to the study area (Kisumu and Kakamega). 
The data was collected in several stages. Initially interviews were conducted with various officials $^{3}$ at the County level that included the District Agricultural Officers, District Development Officers, District Environment Officers and District Crops Officers. Information obtained from these interviews was used to guide the selection of study locations ${ }^{4}$. One location was purposely selected from each of the three districts in the County so as to ensure that the study sample was diverse enough to reflect the characteristics of the County population in terms of socio-economic profile as well as ecological variations. The three locations that were included in the study were Shaviringa in Hamisi District, South Maragoli/ Mung'oma in Vihiga District and Echichibulu in Emuhaya District. Administrators at the location level including Chiefs, Assistant Chiefs, Village elders as well as a Parliamentary representative for one of the Constituencies in the County were also interviewed.

At the locational level, focus group discussions of 6 to 8 participants were held to gain a basic understanding of the nature of the local political economy that informed the approach taken in dealing with the research participants. Participants were purposively selected to ensure gender and socio-economic balance. These focus group discussions shed some light on the underlying village politics and helped in making some basic decisions such as who to choose as a gatekeeper and guide while visiting homes. Local administrators from the three locations helped in preparing the sampling frame by listing down all the households in their jurisdiction from which 80 households were randomly selected to participate in the survey. Church and village elders were enlisted as gatekeepers to help locate these homes. In situations where the household head for a selected household was not available during the time of the visit, a nearby household that was not originally included in the sample was picked as a replacement. However, such cases were few since the questionnaires were administered between January and March which is a pre-planting season and most household heads could easily be found at home. This was also made possible by the fact that the March - May long rains failed to come at the expected time and most of the

\footnotetext{
${ }^{3}$ Although a new administrative structure that instituted the creation of Counties was in place at the time of conducting this fieldwork, there were no "County" officials in place and therefore, the District Officials were considered the highest in rank in the County at that time.

${ }^{4}$ A location is the second lowest administrative unit in Kenya's hierarchy of administration. It is administered by a Chief and may have several sub-locations under it administered by Assistant Chiefs who are assisted by handpicked village elders.
} 
farmers had a lot of time to spare since they had finished preparing their farms for planting and were just waiting on the rains.

The questionnaire had six sections that included household demographic characteristics, household assets, income generation activities, land use, climate variability, food (in)security, livelihood change and perceptions on government activities/projects. Most of the questions were objective type with a few open-ended ones. Prior to conducting the surveys, the questionnaire was pretested on ten individuals in one of the locations in the County that other than the study locations. As a result of this, some of the questions that were ambiguous were rephrased or omitted altogether.

At the end of the survey, at least ten households were purposely selected from each of the three study locations for more in depth interviews. The interview guide consisted a range of questions that included changes in livelihood activities, changes in land use, forest loss (this was only asked in Maragoli and Shaviringa), vulnerability to climate variability and perceptions on government funded projects. Both the focus groups discussions and the interviews were recorded using digital audio recorders.

\subsection{Data Analysis}

Quantitative data was analyzed using the SPSS statistical analysis package to generate descriptive and summary statistics on the different variables. Unlike the analysis of quantitative data that was done after all the data had been collected, the analysis of qualitative data was an ongoing process that started during the data collection period. Prior to going into the field, a list of codes was prepared from the themes that were drawn from the research questions. Interviews and focus group discussions were taped and listened to over and over again, to identify phrases and examples of these codes. The taped interviews and discussions were then transcribed and translated into English (in cases where the local Luhyia language or the national Swahili language was used to conduct the interview). The various codes addressing a specific theme were cut and paste in separate files in which specific patterns of consistencies and contradictions that addressed 
the research themes and questions were identified and compared to the results of the quantitative analysis.

\section{Results}

\subsection{Demographic Characteristics}

An analysis of demographic characteristics is an important dimension of studying livelihood studies for a number of reasons. Household demography is indicative of past and present economic status while some of the demographic characteristics are assets/capital that households can draw upon or appropriate to improve their lives. Information on household characteristics such as education levels, type housing and type and quantity of assets was collected and analyzed. The results showed some specific trends that include low levels of education, poor housing conditions and ownership of few assets.

\subsubsection{Low levels of education}

The results of this study indicate that Vihiga residents generally have very low levels of education with primary school level of education being the highest attained by the majority (Fig. 3.3). There are slight gender differences at the secondary school level with more men having attained some years of secondary school education compared to the women. College and university education is limited to very few residents. The inability of many area residents to pursue formal education beyond primary school level can be attributed to the high cost of high school education in Kenya that makes it out of reach for many low income families. The average cost of educating a child through a public secondary school ranges from Kshs. 20,000 (for a day school) to as high as Kshs. 45,000 (in a boarding school) per term ${ }^{5}$. The introduction of Free Primary Education (FPE) in 2003 has seen household expenditure on primary school education decline (Fig. 3.3) and many poor households have taken advantage of this opportunity to enroll their children in school (Bold et al. 2009). This explains why the highest level of education received by children in most households is primary school.

\footnotetext{
${ }^{5}$ A regular school year for public schools has three school terms that run for three consecutive months beginning in January, with one month's break between the terms.
} 


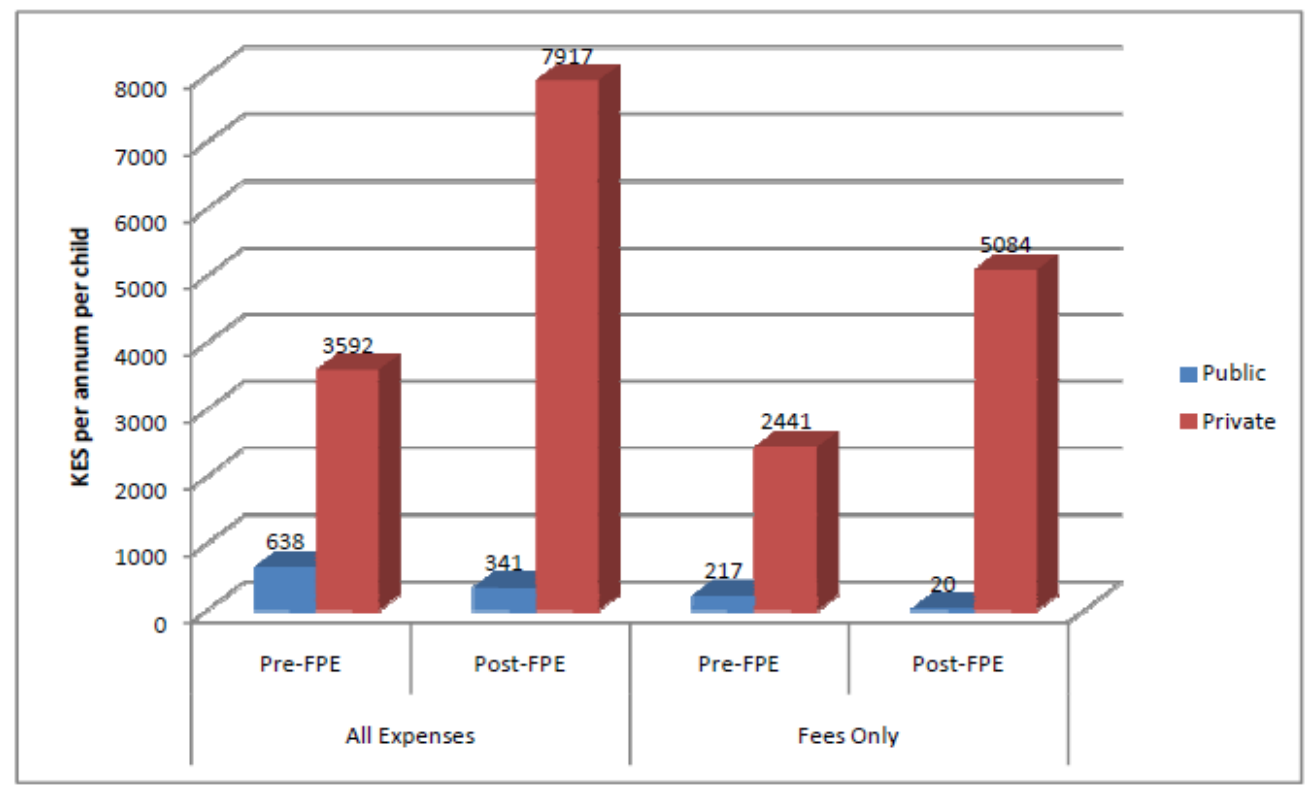

Figure 3.3: Household educational expenditure after the introduction of Free Primary Education

(Source: Bold et al 2009)

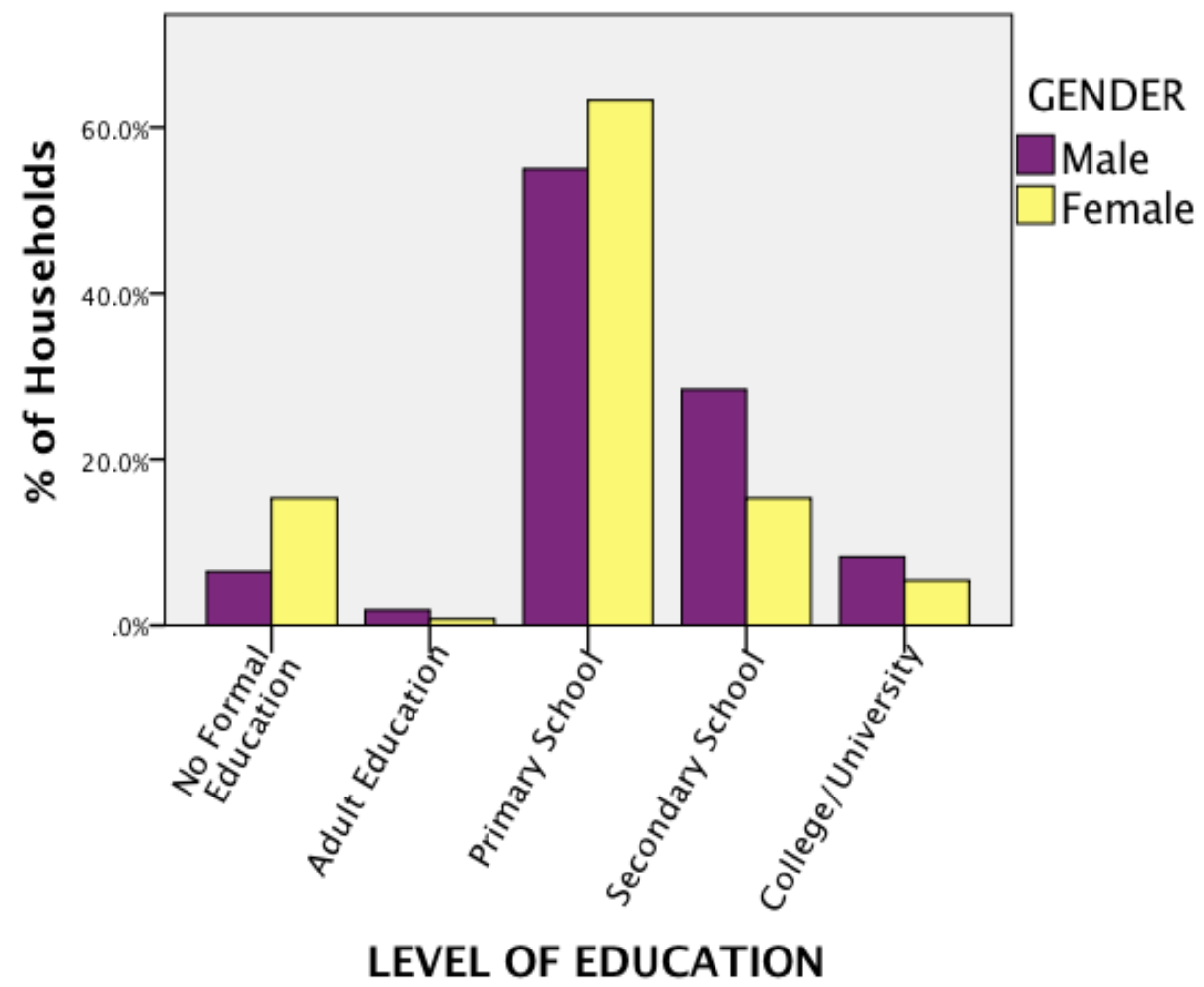

Figure 3.4: Respondents level of education by gender 
The implications of low education levels on career opportunities for family members are profound. With the limited formal education, most Vihiga residents have very few options in terms of career prospects and most work as small scale farmers on their small plots that are barely productive, as unskilled laborers and/or as petty traders (Table 3.1).

Table 3.1: Respondents' and Spouse's main occupation

\begin{tabular}{|l|l|l|}
\hline Occupation & Respondent $(\%)$ & Respondent's spouse(\%) \\
\hline Unskilled laborer & 9.5 & 7.5 \\
\hline Civil servant & 5.0 & 6.3 \\
\hline Petty trader & 2.5 & 2.1 \\
\hline Business & 7.1 & 5.8 \\
\hline $\begin{array}{l}\text { Small scale } \\
\text { farmer }\end{array}$ & 68.7 & 48.3 \\
\hline Other & 7.1 & 10.8 \\
\hline
\end{tabular}

Parents who have not attained higher levels of education and subsequently have low income levels and therefore lack the financial resources to send their children to secondary school. The number of children per household in the study ranged from 0 to 27 (the highest number was from a polygamous household) with a mode of 4 and a mean of 6.1. Children in the Luhyia culture tend to be regarded as assets, and having more children is a form of risk aversion strategy. Children's education has been seen as a form of investment that "would later give rise to regular remittances" (Francis \& Hoddinot 1993, p. 125) In recent decades though, the inevitable burden that poor households are confronted with of feeding, clothing and educating their children is challenging these cultural notions (Lay et al. 2008). Over $90 \%$ of the households 
did not have any children who had received university education with only 22 households having at least one child with university level education with slight variations between the three districts Vihiga (7), Hamisi (9) and Emuhaya (6). None of the children in $37.5 \%$ of the study households had received any high school education while all the children in $75.8 \%$ of the households had received some primary school level education.

In the past, individuals who received post-secondary training either at the universities and mid-level colleges were assured of getting a fairly well paying formal job which often translated into regular remittances to the family. The results of this study, however, indicated that this trend is changing as the rate of national unemployment rises. The US Agency for International Development reported Kenya's unemployment rate in September 2012 to be $40 \%$ of which $67 \%$ are youth ( 15 - 30 years old) (http://kenya.usaid.gov/programs/economic-growth). After selling family assets like land and livestock and investing most of their income in their children's education, many households are finding themselves poorer after the children complete their studies and are unable to find the high paying jobs or even any jobs at all. The inevitable outcome of this trend is that households that previously considered themselves as middle-income class are gradually sinking into poverty.

In one such household, the father had been a senior administrator at a nearby sugar factory and had a fairly good income which he invested in his children's education, sending some of them to universities outside of the country with the hope that they would secure well-paying jobs. This did not turn out to be the case, and now this household's economic situation is worse than it was about two decades ago; his house is in disrepair and there is no money to fix the car. Although the father is still considered one of the prominent tea farmers in the village, he is barely making ends meet as he now has the added burden of educating his grandchildren. While this case appeared to stand out because of the family's previous economic status, it reflects in many ways what is happening around the county as more households become poorer. Apparently, the introduction of Free Primary Education has not translated into tangible positive outcomes for most households in Vihiga. 


\subsubsection{Poor living conditions}

Apart from having low levels of education, the living conditions for most of the households in Vihiga are deplorable. Over $75 \%$ of the study households live in "semi-permanent" houses with roofs made out of corrugated iron-sheets with mud walls and floors. Only $20 \%$ of the study households had "permanent" houses that have stone or brick walls and cemented flooring that are indicators for current or past high economic status (Fig. 3.5).

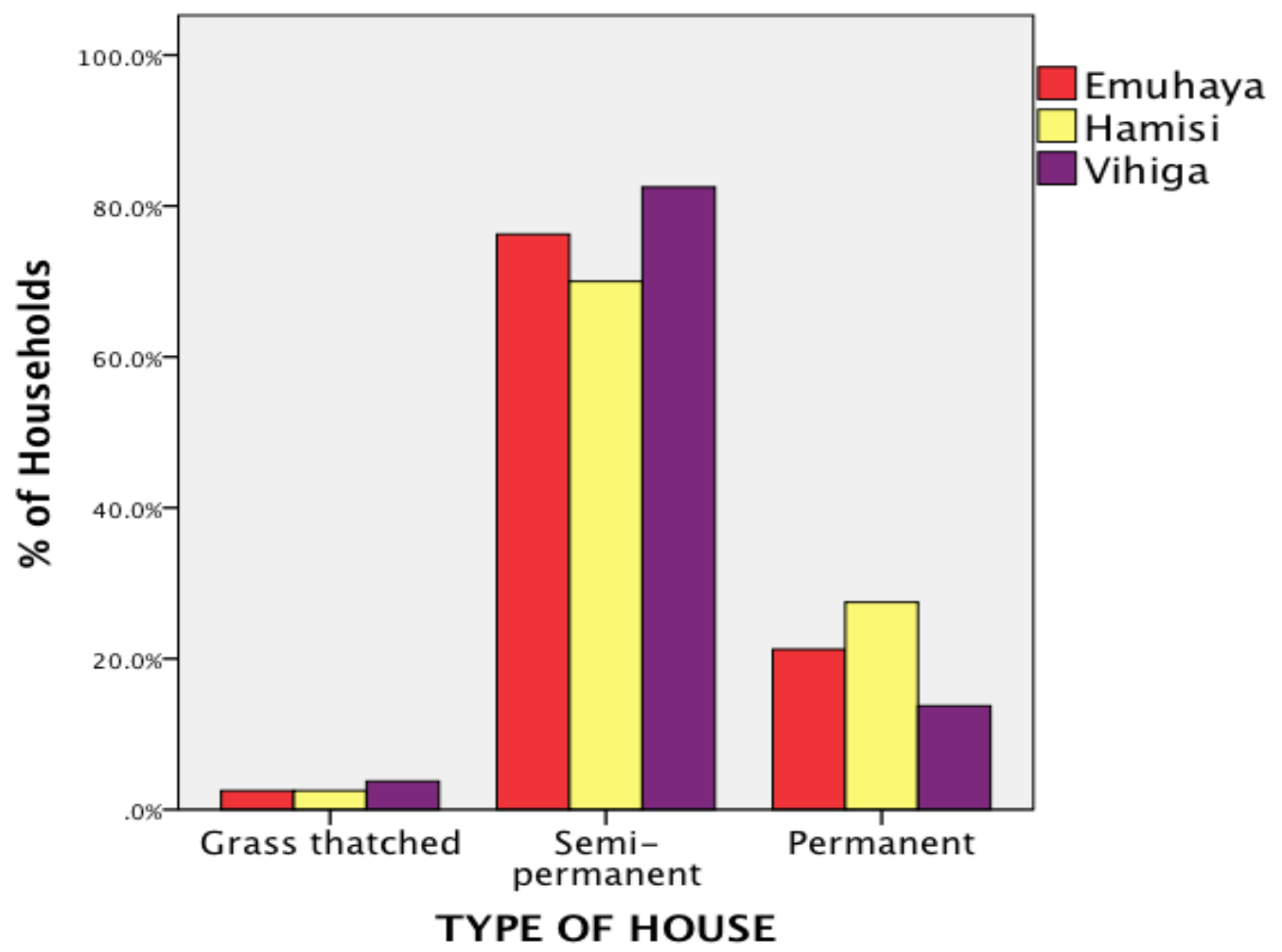

Figure 3.5: Type of Housing

Access to clean and safe water for domestic use is equally poor with over $70 \%$ of the study households getting their water from nearby streams and creeks. Some of the respondents indicated that recently there seemed to have been an increase in the occurrence of waterborne diseases. Access to electricity is still very limited and so kerosene and firewood are the most commonly used fuels for lighting and cooking respectively. Even worse still with the lack of wooded areas, many households are having limited access to firewood for food preparation. Many of the households with relatively larger parcels of land now practice agroforestry to meet 
this need. For many households, however, the fuelwood crisis is presenting a new set of challenges in a far as food preparation is concerned.

\subsubsection{Few or lack of high value assets}

One of the indicators of resilient livelihoods is the ownership of assets that can be disposed of in times of stress to meet pressing needs. Assets owned by members of a household collectively or individually are not only indicators of socio-economic status but also can be a form of insurance for the household in times of need. Ownership of electronic devices in Vihiga is limited by the lack of access to electricity. Only $28.7 \%$ of the households owned at least one television set but $80 \%$ owned at least a battery operated radio. Ownership of cellphones, however, is very high with $78.7 \%$ of the households having at least one cellphone. Car and motorbike ownership was extremely low with only eight households owning at least one car while only 11 households owned at least one motorbike. Ownership of bicycles was relatively higher with 64 households indicating that they owned at least one bicycle. The positive side of this trend is that bicycles are an eco-friendly means of transportation. Vihiga residents, however, do not ride bicycles because of the environmental benefits but because that is what they can afford.

Ownership of livestock is not only an indicator of economic well-being in this area but also reflects on a household's social status. Livestock are often used to fulfill social obligations such as dowry payment and are often slaughtered during funerals and celebrations. Some respondents indicated that keeping livestock is a form of risk aversion and they were not necessarily interested in the immediate economic returns. On many occasions, livestock is sold to take care of family needs such as sickness, payment of school fees and funeral expenses. However, this long held risk aversion strategy is now limited to a few households. With common grazing grounds having disappeared over the years, owning large stocks of animals is now limited to those households with other sources of income that can enable them practice intensive livestock keeping techniques such as zero-grazing. Aggressive campaigns initiated by NGOs and implemented through the Ministry of Agriculture that focused on encouraging area residents to switch to cross bred livestock as an economic strategy have not been successful as most households still choose to keep the local variety of livestock. Most cite the initial cost of owning 
the exotic variety of livestock as well as their maintenance costs as being prohibitive. In this study, only 54 households had at least one cross bred dairy cow. Over $60 \%$ of these households had kept this breed of cows for more than five years. On the other hand, ownership of the local Zebu breed of cattle was relatively higher with 155 households having at least one such breed. Slight variations in the type and quantity of livestock kept existed across the three study districts.

Only 5 households (4 in Emuhaya and 1 in Hamisi) kept cross bred dairy goats compared to the 50 who kept the local type of goats. Of this latter category, 34 households were from Vihiga compared to 12 from Emuhaya and 4 from Hamisi. Only 4 households (3 in Hamisi and one in Vihiga) kept "grade" chickens compared to $82.9 \%$ who kept the local variety of chickens. Ownership of other livestock like sheep and pigs was negligible with only 16 households keeping sheep and one household keeping pigs. Most of the respondents indicated that limited resources, especially money, prohibited them from keeping improved breeds of livestock that can generate some form of income. In Shaviringa, the ability to keep large stocks of livestock had been curtailed after the enclosure of Kibiri forest and now residents who previously could freely graze their livestock in the forest have to purchase a permit from the Forest Department in order to have access the forest.

Respondents also lamented the lack of agricultural extension services as one of the issues contributing to reluctance to adopt "grade" livestock. Coupled with this is the inability to access veterinary services which had led to loss of livestock for some households. Given the high cost of "grade" livestock and the investment that goes into keeping them, the thought of losing them again due to lack of veterinary services is enough to discourage most of the households. This analysis of the demographic characteristics shows majority of Vihiga households as poor and therefore in need of subsidized services that are provided by the state such as agricultural extension services that were provided in the pre-neoliberal economic regime. The scaling back of these services therefore has compromised the ability of these households to pursue certain livelihood options. 


\subsection{Livelihood Activities}

\subsubsection{Cash crop production}

The ability of Vihiga households to engage in cash crop production remains limited due to their small parcels of land. Some households have however, found innovative ways to use the portions of their land that are not very productive to grow trees which they sell locally to individuals. This was the most practiced form of cash crop production reported by $15.4 \%$ of the households. Respondents indicated the fact that trees require minimal inputs and care and can grow in less fertile and poor soils where other types of crops may not do so well as the incentive for this strategy. The eucalyptus species is the commonly grown type because it matures faster than the indigenous species of trees. Of the 37 households that grew trees for sale, $59.5 \%$ were from Vihiga District. Selling of trees has become a viable income generating activity for these households because of the high demand for firewood which is used as cooking fuel by $89.6 \%$ of the study households.

Of the other crops that are grown in this area, tea and bananas were the more common cash crops even though the percentages of the households engaged in their production were relatively low. Tea was grown by only $12.5 \%$ of the households with $60 \%$ of them from Hamisi District. Similarly, bananas for sale were grown by $14.5 \%$ of the households of which $54.3 \%$ were from also from Hamisi. Of the households engaged in tea production, $50 \%$ had grown the tea for more than 20 years with only $13 \%$ indicating that they had only grown the tea for less than five years. All the tea that is grown in the County is delivered to Kenya Tea Development Agency buying centers in the County and later transported to Mudete Tea Factory for processing.

Most of the tea that is grown in Vihiga is exported, but there are indications that tea farmers are barely making any profits from this venture. At the time of conducting this study (2010-2011) farmers were paid Kshs. 12 (15 US cents) ${ }^{6}$ every month for every kilo of tea delivered that month. At the end of the year, they would also be paid what is referred to as a "bonus" and the amount of the "bonus" depended on the global tea market. In 2010, tea farmers received a "bonus" of Kshs. 25 (30 cents) for every kilo they delivered in the year and that was the highest they had ever received. Overall, the total amount of money made from one kilogram

${ }^{6} 1$ USD $=83$ Kenya Shillings (March 2011) 
of tea during that year was Kshs. 37. The actual take home pay was even smaller after KTDA deducted the cost of the fertilizer that they had "loaned" the farmers in the course of the year to top dress the tea bushes. And many of the farmers did not even include the cost of the labor that they hired occasionally to help on the farms. One of the farmers did acknowledge that he was actually making losses but contended that the "bonus" that he looked forward to receiving every year was incentive enough to continue growing the tea in spite of the losses. Most of the farmers are actually cognizant of this fact but they choose to continue to grow tea, partly because it is a form of status symbol. This kind of thinking can be traced back to the late colonial period when agricultural officers only allowed a few individuals who had large sizable portions of land to grow coffee.

However, low economic returns are not the only problem bothering tea farmers in Vihiga. The current variability in the weather patterns with prolonged spells of drought also threatens the continued viability of tea as a reliable cash crop (Fig. 3.6). Tea farmers in Vihiga are not only vulnerable to fluctuations in the global tea market that dictates how much they get from the crop but they are also vulnerable to recurrent variability in the climate that are affecting the crop. This situation exemplifies what Leichenko \& O’Brien (2008) refer to as 'double exposure'.

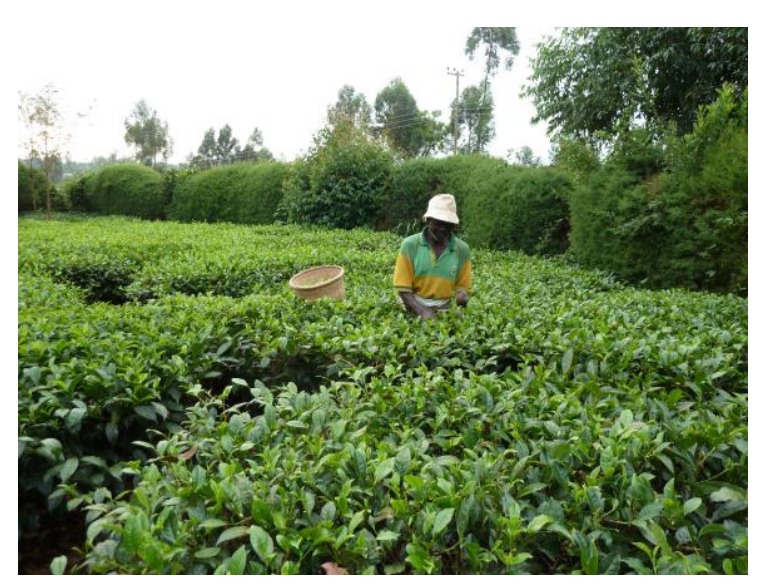

a.) Picture taken on Dec. 30, 2010

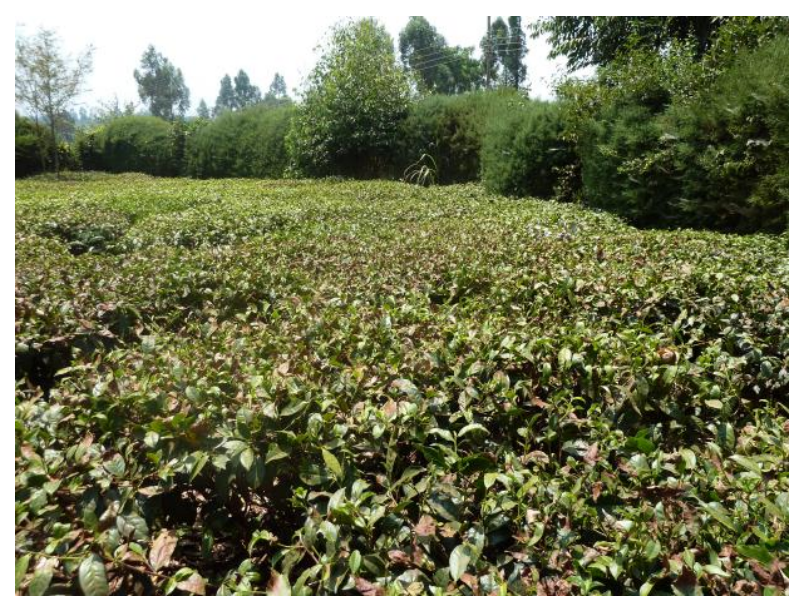

b. ) Picture of the same farm taken on Feb. 12, 2011 showing desiccation of the tea due to a prolonged dry spell

Figure 3.6: Impact of prolonged dry spells on the tea crop

Source: Author (March 2011) 
Other crops produced for sale include maize, beans, napier grass (used to feed livestock), sweet potatoes, tomatoes, fruits and vegetables (Table 3.2). An interesting observation is the absence of coffee amongst the cash crops that are grown by the study households. Growing of coffee in this area began in the 1950s after local leaders put pressure on the colonial government to allow African farmers to grow the crop (Maxon 2003). Initial restrictions imposed by the colonial government that only allowed farmers with over 7 hectares of land to grow the crop were eventually relaxed and many more farmers were able to plant coffee in post independent Vihiga. By the early 1990s, both tea and coffee were the major industrial cash crops in Vihiga, covering an area of 1640 and 1199 hectares respectively (Vihiga District Annual Report 1996). However, by 2008 coffee production had declined to 20.1 hectares compared to the 787.8 hectares under tea (Vihiga District Annual Agricultural Report 2008). The Agricultural Report (2008) attributes this decline to a number of factors that include "farmers" negligence of the crop, high cost of fertilizers to top dress the crop, poor management of the crop cooperative societies and low returns from the produce" (p. 17). These issues were echoed by one of the Agricultural officers who stated that:

Coffee was very dominant but it has now gone but tea is still there. The coffee has not gone because people don't like it but it is because of the land - the subdivision of the land. You see if you have five sons, even if you had 8 acres and it is subdivided then everyone is left with smaller pieces and not everyone is interested in coffee. And if you have a small coffee farm, it is uneconomical so you end up destroying everything. Secondly, in the case of coffee, it was also the economic crisis whereby income per capita was low and there was a lot of theft in the cooperative societies and this demoralized the farmers. (Peter Lodenyo, Vihiga District Crops Officer, Interview Feb 2011)

What these results indicate is that cash crop production is no longer a viable livelihood option for most households in Vihiga County due to a combination of economic, environmental, political and socio-cultural factors. As such, neoliberal policies that are push for production for the market as opposed to production for subsistence are unlikely to benefit many Vihiga households. Most of the study participants indicated that they stand to benefit more from more direct state intervention such as the distribution of farm inputs, which would improve agricultural productivity and subsequently enhance food security. 
Table 3.2: Cash crop Production

\begin{tabular}{|l|l|}
\hline Crop & \% of Households \\
\hline Trees & 15.4 \\
\hline Bananas & 14.7 \\
\hline Tea & 12.5 \\
\hline Vegetables & 9.1 \\
\hline Napier Grass & 3.3 \\
\hline Fruits & 3.3 \\
\hline Maize & 2.9 \\
\hline Beans & 2.2 \\
\hline Sweet Potatoes & 1.7 \\
\hline Tomatoes & 0.8 \\
\hline
\end{tabular}

\subsubsection{Petty businesses}

As noted by Maxon (2003), petty businesses emerged in Vihiga in the 1940s as a part of the livelihood diversification strategy. This study sought to find out if in fact this activity is still pursued by many households and the types of petty businesses that households engaged in. Interestingly, the results indicated that very few households had members engaging in such some form of business. For those who did, the types of businesses included trading in cereals (such as maize, beans, sorghum and millet), fruits and vegetables, carpentry and tailoring (Table 3.3). 
Trading in fruits and vegetables was the most common business engaged in by members of 28 households (11.7\%). This kind of trade is dominated by women (21 households) who purchase the vegetables and fruits from merchants bringing the produce from neighboring counties and then repackaged and sold them locally for a minimal profit.

Table 3.3: Types of businesses members of the study households engage in.

\begin{tabular}{|l|l|}
\hline Type of Business & \% of Households \\
\hline Fruit and vegetables & 11.7 \\
\hline Transportation & 6.3 \\
\hline Cereals & 6.3 \\
\hline Retail Shops (Duka) & 5.4 \\
\hline Carpentry & 5.4 \\
\hline Welding & 1.3 \\
\hline Hawking & 1.7 \\
\hline Used clothes & 1.7 \\
\hline Seamstresses/Tailors & 4.2 \\
\hline Others & 2.5 \\
\hline
\end{tabular}

Transportation and selling cereals were the next most popular businesses with members from 15 households engaged in each type. Just like the fruits and vegetables business, trading in cereals was dominated by women who purchased the grains from merchants and middlemen and 
then sold them in smaller units locally by the roadside or at the local markets for a minimal profit. The transportation business was dominated by motorbike taxi operators who ferry people from the interior parts of the county where there is no public vehicle service. Most of the operators however were young men who in most cases did not actually own the motorbikes but were contracted by the motorbike owners and earned a daily wage.

Other types of businesses included operating retail shops ( $d u k a)(5.4 \%)$, carpentry workshop (5.4\%), welding workshop (1.3\%), hawking of wares (1.7\%), selling used clothes (mitumba) (1.7\%) and tailoring (seamstresses) (4.2\%). At least one household had a member engaged in brick-making, masonry, operating a maize mill (posho mill), hair salon, selling charcoal and firewood, selling sugarcane, operating a food kiosk, selling livestock, pottery and basket weaving. Only three households in the study sample had members engaged in high-return enterprises that involved large investments. In one of the household, one of the sons was a shareholder in a car hire company in a nearby town while two of the households owned private primary schools within the county. These results indicate that even though farming as a livelihood and income generating activity is no longer viable for most Vihiga households, few of them have the capital to engage in business, however petty. Furthermore, most individuals who are able to engage in businesses only venture in the kind that have extremely low returns and mainly for survival and not accumulation. These results reinforce Lay et al's (2008) results that indicated that the rural non-agricultural sector in Kakamega District (also in western Kenya) is dominated by low-return activities and in which they concluded that high - return activities aggravate existing inequalities since they are a preserve for very few households.

\subsubsection{Wage Income}

The migration of adults males in Vihiga to urban towns such as Kisumu, Kakamega and Eldoret and even as far as Nairobi is another trend that is identified by Maxon (2003) as having begun in the 1940s as households sought to diversify their livelihood strategies. This trend served to provide reprieve for a region hard pressed with declining land resource. This study sought to examine whether this strategy was still central to livelihood diversification by identifying which members of the households worked away from home and earned a regular income. The results 
showed that fathers in $10.4 \%$ of the households and sons in $28.3 \%$ of the households worked as migrant workers (Table 3.4).

Table 3.4: Percentage of Household members in Salaried employment

\begin{tabular}{|l|l|}
\hline Member of household & \% of households \\
\hline Father & 10.4 \\
\hline Mothers & 2.1 \\
\hline Son(s) & 28.3 \\
\hline Daughter(s) & 12.9 \\
\hline
\end{tabular}

Most of the employed sons (64.7\%) worked either in Nairobi or in one of the towns/cities away from home. Only 31 (12.9\%) households had daughters who were employed with 20 of them working in a city or town, while 16 of them were engaged in professional jobs. The low numbers of migrant workers registered in this study reflect the high levels of unemployment in Kenya but also the inability of Vihiga youth to compete favorably in the national job market due to their low levels of education. This trend is also attributed to the closing of numerous manufacturing firms in nearby towns that offered employment to many young people from Vihiga. Four of such firms that closed down in the 1990s are the Kisumu Cotton Mills (KICOMI) in Kisumu town, the Raymonds Textiles, Ken Knit and Rift Valley Textiles (RIVATEX) in Eldoret Town. These textiles firms closed down since their products could not compete with cheap imported textile products made available on the local market as a result of the free market economy. 
Table 3.5: Other Sources of Income

\begin{tabular}{|l|l|}
\hline Source of Income & \% Households \\
\hline Remittances & 44.2 \\
\hline Collecting rent & 3.3 \\
\hline Pension & 5 \\
\hline Gifts from friends and family & 1.7 \\
\hline Membership to social groups & 1.7 \\
\hline
\end{tabular}

In spite of the low numbers of migrant workers, remittances from those who were able to find jobs are still a relatively significant source of income for $44.2 \%$ of the households (Table 3.5). However, most of the respondents lamented that remittances were no longer reliable with $52.8 \%$ of them indicating that they only received the remittances once in a while. This trend could partly be due to the high rate of inflation that makes it difficult for working family members to have enough money to meet their needs and also remit money to their families regularly. Many respondents, however, did acknowledge the fact the recent trend of transferring money instantly via cell phone technology, commonly known in Kenya as MPESA has made the process of receiving remittances much easier and convenient.

Other sources of income included rent collected from property (3.3\%), pension (5\%), gifts from family and friends and occasional dividends from group membership and company shares. None of the households acknowledged receiving government support even though some households in Vihiga had benefitted from a government project that involved distribution of farm inputs. Support from friends and family, which was a fairly common support strategy in the past is no longer in existence as expressed by one of the respondents: 
Right now it is hard to get any assistance from relatives. If you go to them they will tell you, "Look at me, is there any difference between you and me?" And so we are all the same. (Mzee Otiende, Muguva Village - Vihiga District, Vihiga County - Personal Communication)

Although wage income and remittances have been an important livelihood option for many households in Vihiga, these findings show this is no longer an option for many of the households. This can be attributed to the high unemployment rates in the country and to the closing down of several manufacturing industries that made this option possible before the implementation of neoliberal economic policies.

\subsubsection{Changes in Level of Income}

In order to examine overall trends in the livelihood change trajectories, respondents were asked to rate their income levels over the past 5, 10 and $15^{7}$ years. Most of the respondents reported a decline in income levels with $65.4 \%$ indicating that their level of income was lower than it had been five years ago, 56.7\% indicating that it was lower than it had been 10 years ago and $57.5 \%$ indicating that they were better off 15 years ago than they were in 2011. Some of the reasons given for the decline in income levels included the high cost of living caused by inflation, unemployment, death of the breadwinner and paying children's school fees. Fewer households indicated that their income status had improved with $16.3 \%$ indicating that it was better than 5 years ago and $21.2 \%$ indicating that it was better than it had been 15 years ago. Some of the reasons cited for this improvement include successful business and farming ventures, completing paying fees for children and membership to self-help groups.

Overall, the livelihood activities of Vihiga households appear to be less diverse. Most of the options for diversification such as wage income, remittances, petty businesses and cash crop production are no longer viable for many households. While local conditions such as the shrinking farm sizes have contributed to this situation, the implementation of some neoliberal

\footnotetext{
${ }^{7} 15$ years was chosen as the maximum threshold for recalling past income levels so as to ensure responses from most of the participants who were in their mid-30s and below
} 
policies has complicated this problem further. This, inevitably, makes Vihiga one of the poorest Counties in Kenya, in spite of its high agricultural potential.

\subsection{Land Use Strategies and Implications for Food Security}

\subsubsection{Land Size}

Most studies conducted in Vihiga have reiterated the continuing challenges that households are confronted with in the dwindling sizes of the land that they have access to (e.g. Maxon 2003, Shanguhyia 2007, Crowley and Carter 2001, Swallow 2005, Walingo 2008, Francis \& Hoddinot 1993, Kitching 1980). The size of the land owned by the household is not only an important dynamic in food security but can also be used as leverage for engaging in high-return non-agricultural activities since it can be used as collateral to obtain loans for starting businesses or other similar income- generating activities. This study sought to find out the household farm sizes as well as the different uses that households put their farms to. The results indicated that $88.6 \%$ of the study households owned less than $2^{8}$ acres of land while only $5.42 \%$ owned more than 4 acres of land with slight variations across the four locations. Over $70 \%$ of the households did not have any other pieces of land other than the ones on which their homes stood while $47.8 \%$ of those who had other pieces of land were from Vihiga district. Over $90 \%$ of the households had cultivated all the land that they owned and only $13.8 \%$ indicated that they leased land to supplement what they owned. However, of the 33 households that leased land, 19 indicated that their leased land was less than half an acre. Most of households leasing land were from Emuhaya (17) and Hamisi(17) locations with only one household in Vihiga. Over half of the respondents in Hamisi had allocated a portion of their land to cash crop production and most of the cash crops were either sold on the farm to individuals, at the local market or factory (mainly the tea).

\subsubsection{Access to Inputs}

As land sizes continue to diminish and the land is perpetually under cultivation with no fallowing period, it has become necessary to use commercial agricultural inputs to realize any

\footnotetext{
${ }^{8}$ These figures are based on estimates given by respondents. It was noted that many of them did not know the exact size of their farms and many of the figures were either underestimated or overestimated.
} 
reasonable yields, especially for maize production. Maize is the staple food for Vihiga residents and often lack or scarcity of maize is synonymous with hunger. Although the use of higher yielding varieties of seeds as well as synthetic fertilizers makes households dependent on the market for their supply of seeds, it is the only viable way to increase yields on their small parcels of land. This study sought to examine how accessible such inputs are to Vihiga households and the implications on food production. The results indicated that a fairly large proportion of the study households did not use the commercial inputs and hence their maize yields were quite low. Only $11.3 \%$ of the households planted high yielding hybrid seeds compared to $48.8 \%$ who planted the local variety while 39.2\% indicated that they planted both varieties (Figs. $3.7 \&$ 3.8). Most of the respondents who planted both varieties indicated that they preferred to plant the hybrid variety during the long rains season in March which is considered the main planting season but planted the local variety during the short rains season in October.

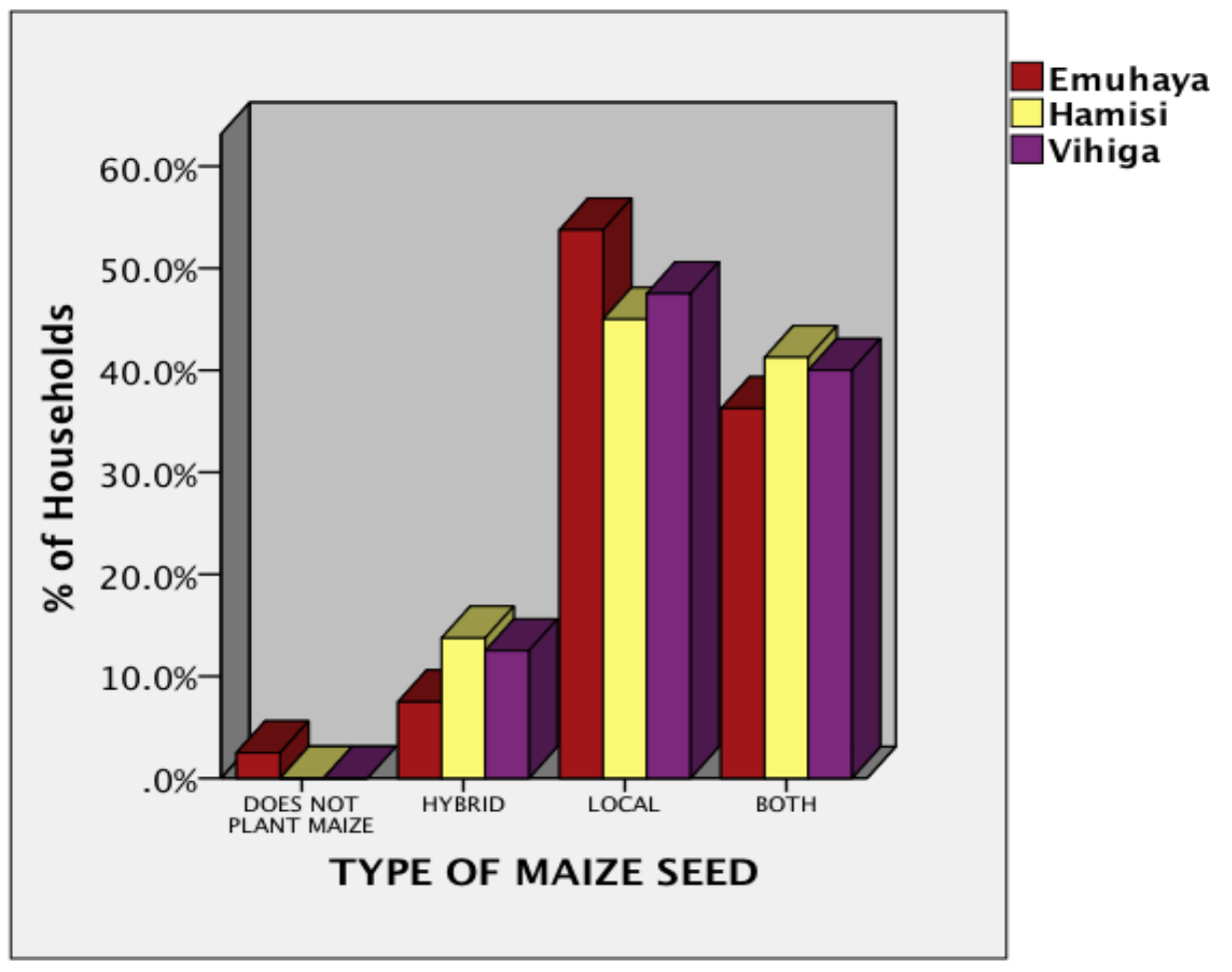

Figure 3.7: Type of Maize Seeds grown 
Use of inorganic fertilizers was equally low with only $30 \%$ of the households indicating their use while $34.6 \%$ used animal manure and 35\% indicated that they used both (Fig. 3.8). The low use of animal manure on the farms is due to the fact that few households keep livestock. These results could have been different if it had not been for the fact that a few households in Vihiga District had benefited from a government project, the National Accelerated Input Program (NAIP), in 2010 where free inputs were distributed. Many of those who benefitted from this program indicated that this had been the first time for them to plant hybrid seeds and use commercial fertilizer on their farms. There were complaints from those who were not beneficiaries of the program concerning the lack of transparency in the process of selecting the project beneficiaries. The same program was underway in Hamisi District during the fieldwork period and similar complaints were also expressed by those who had not been shortlisted to benefit from the program. In fact, some of the households that were in the study had no idea that such a program was being implemented in their location.

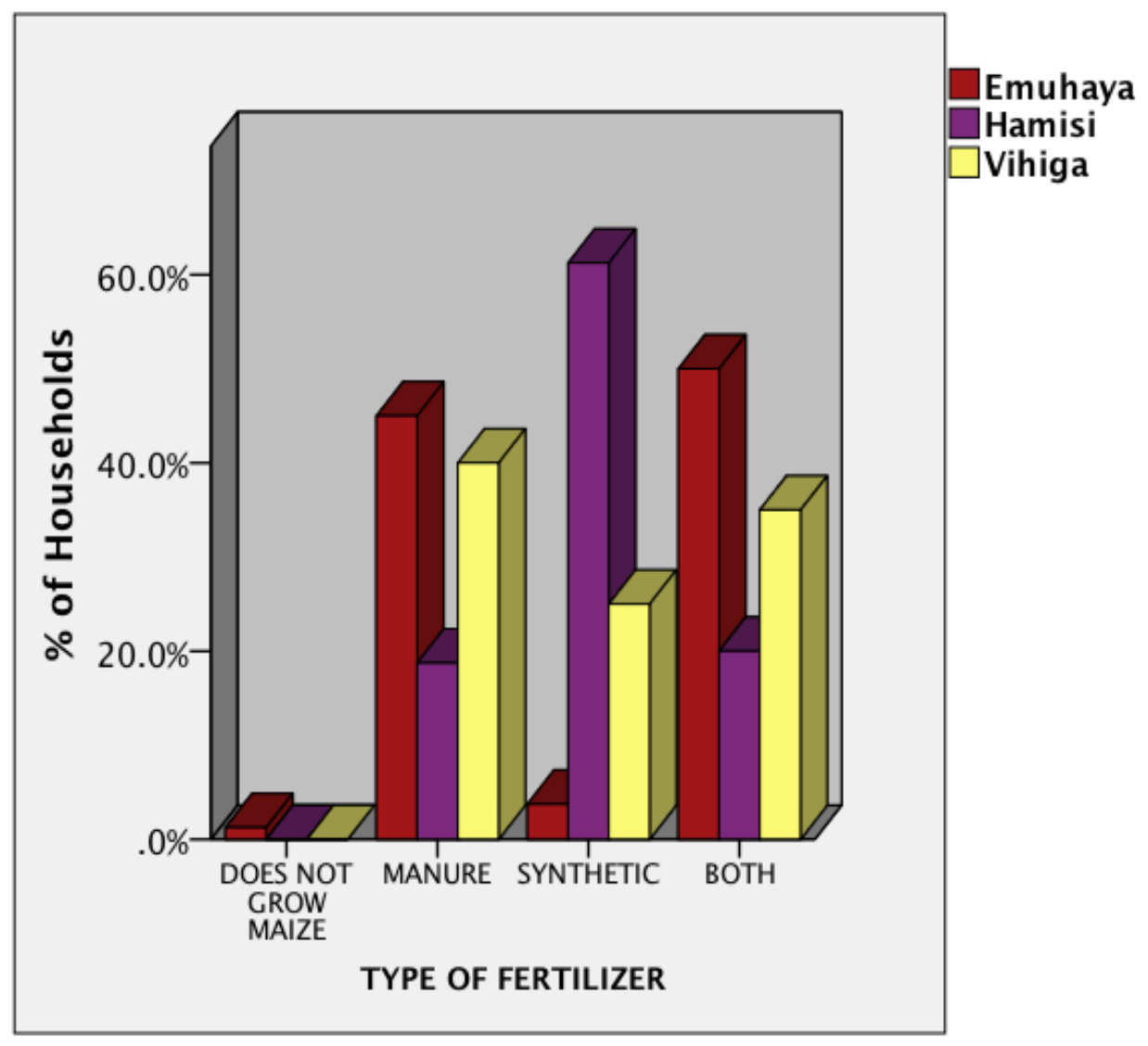

Figure 3.8: Fertilizer Use 
Most of the respondents interviewed indicated that the high cost of inputs prohibited them from using them on their farms. This reinforces Oya's (2007) argument that liberalization in the agrarian sector has contributed to declining productivity. However, while the use of commercial inputs may increase the farm productivity and enhance household food and livelihood security, it also creates an artificial dependence on these inputs that benefit international multinational corporations. The use of the local variety of seeds, on the other hand, may not yield much output but does not create dependence and the use of biodegradable animal manure is less hazardous to human health. Furthermore, use of inorganic fertilizers in the long run may contaminate surface water sources which provide water for domestic use for over $70 \%$ of the area population. In their study of water pollution in Soshanguve in South Africa Nkwonta and Ochieng (2009) found fertilizers and pesticides to contribute over $60 \%$ of the pollution in nearby streams.

\subsubsection{Variations in Rainfall Patterns}

Like most other parts of rural Africa, agriculture in Vihiga is rain-fed and the slightest changes in rainfall patterns are bound to have significant effects on productivity. This study sought to examine the varied ways in which variations in rainfall patterns impacted on land use. Over $90 \%$ of the households indicated that they had observed significant changes in the local rainfall regime with $84 \%$ indicating that the amount of rainfall had declined and the timing on both the long and short rains had become increasingly erratic. Rainfall data obtained from the nearest meteorological stations in Kakamega and Kisumu show patterns of slight fluctuations in the amount of rainfall and variations in the timing of the onset of rains over the past five decades. These variations appear to be more distinct in the 1990s compared to the other decades (Fig. 3.9). The graphs also show shifts in the timing and peaking of the short rains across the decadal means. The meteorological stations are located about $35 \mathrm{~km}$ on average to the north-west (Kakamega) and south (Kisumu) of the study sites and hence the data may not adequately reflect the microclimates within the study sites. They, however, give an idea of the general precipitation trends within this Lake Victoria basin in which Vihiga County falls. 


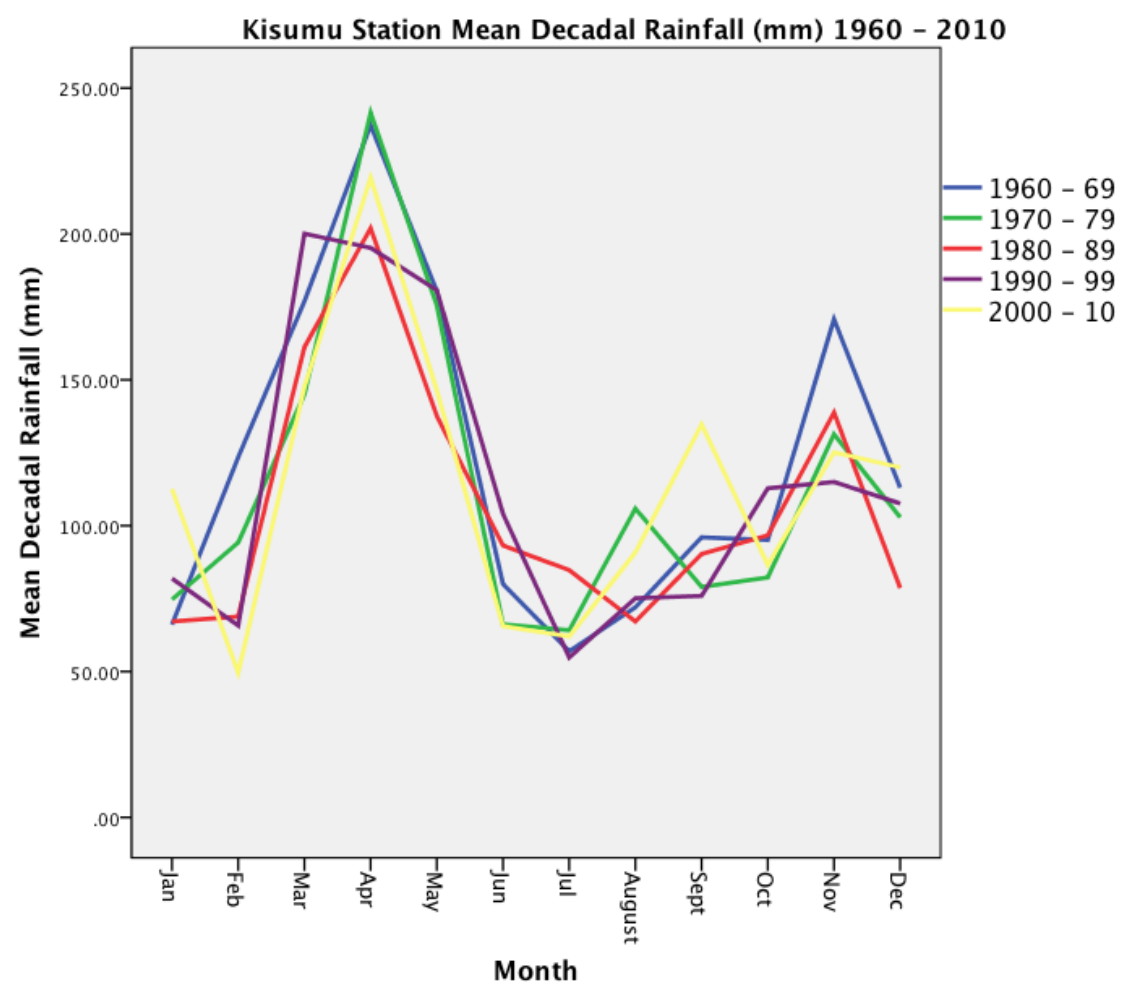

Figure 3.9: Kisumu Station Decadal Rainfall 1960 - 2010

The variations shown in the graphs support the observations made by the respondents. Respondents indicated that such sudden onset of rainfall when the short rains season maize crop was mature but not ready for harvest causes loss of crop as the maize rots on the farm. Apart from the shifts observed in decadal means, rainfall shifts were also observed between individual years as shown in the (Fig. 3.9 \& 3.10). For instance, in 2010, the rains appear to have peaked in April rather than in March as is often expected, while the mean rainfall during that month was higher than previous years. 


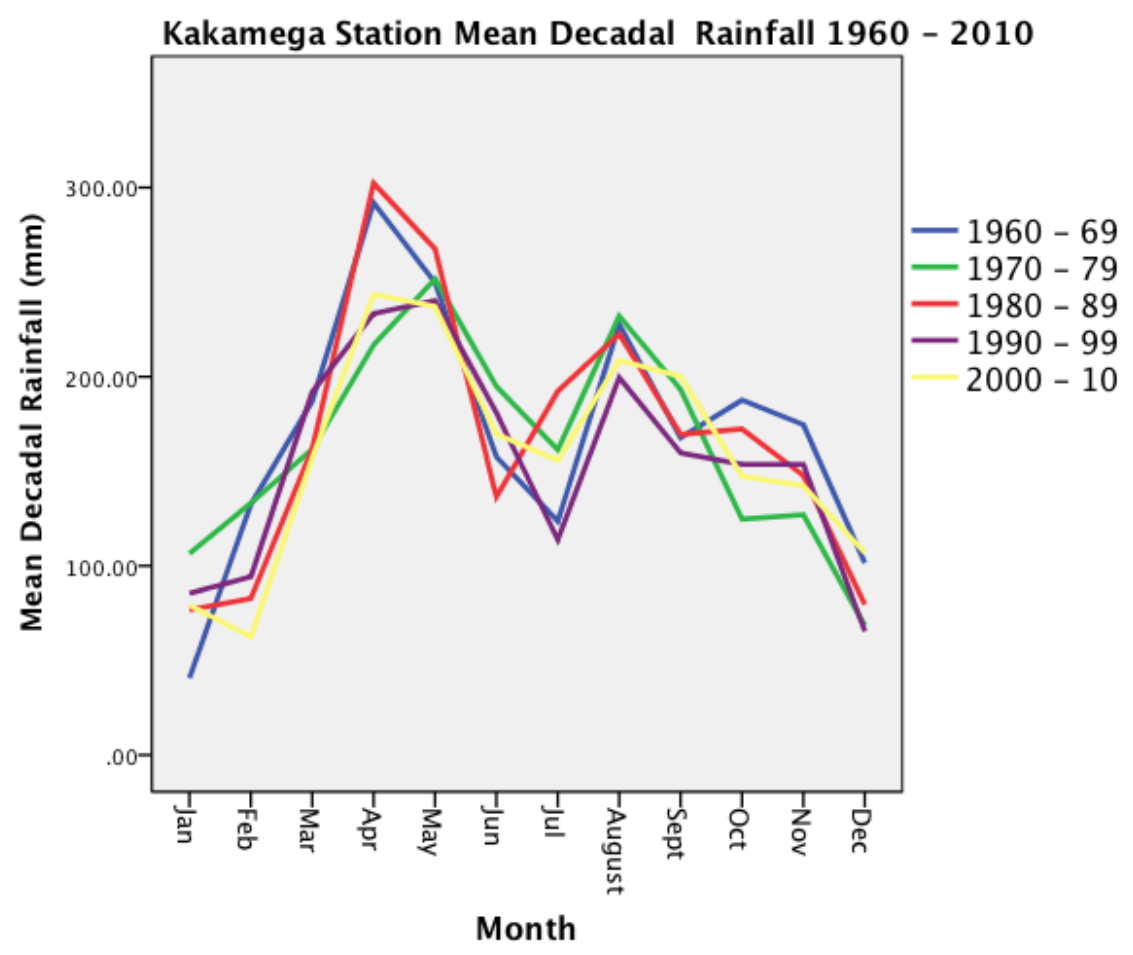

Figure 3.10: Kakamega Station Decadal Rainfall 1960 - 2010 

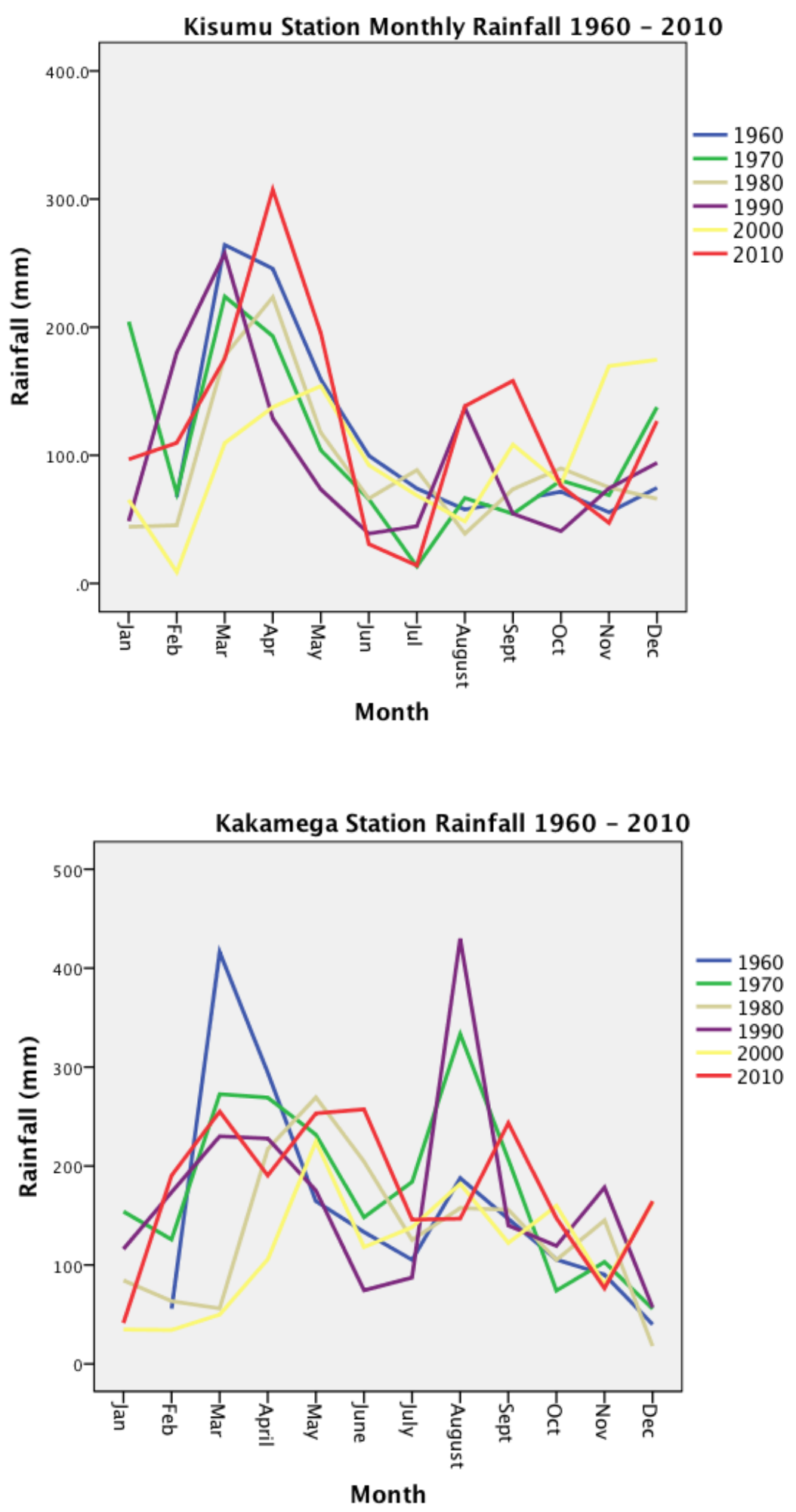

Figure 3.11: Kisumu and Kakamega Stations Annual Rainfall, 1960 - 2010 
With the perception that the timing of the rains is becoming haphazard, the inability to predict the onset of the rains appears to be the biggest climate issue facing Vihiga residents. The implications for this trend is that the planting season is also now erratic with most of the farmers indicating that they wait for the rains to come before they plant and lately, this is later than the usual planting time with implications for the amount of crop harvested. As mentioned earlier, the prolonged dry spells are also affecting tea production and subsequently the returns from tea drop significantly especially between January and March.

\subsubsection{Food Security}

The most immediate need for most Vihiga households is the ability to meet their food needs. While own production has always been the first line of meeting this need, many of the respondents indicated that they have come to rely on the market for most of their food needs. A significant majority of the farmers were only able to harvest $1 / 2$ to 2 bags $^{9}$ in what would be considered a good year when the rains come on time and the farmer uses certified seeds and fertilizer. In what they considered to be a bad year, $60 \%$ of the households harvest less than $1 / 2 \mathrm{a}$ bag of maize which barely lasts a month depending on the size of the household. While this is not exactly a new issue in the region, there are indications that it is becoming worse due to a combination of factors that include the adoption of neoliberal policies in the agrarian sector. One local administrator captured this scenario adequately in his quip, "We now live like we are in the city" (Setsi Jiveti, Chief - Shaviringa Location, personal communication).

\footnotetext{
${ }^{9} 1$ bag of maize weighs 90 kilograms
} 


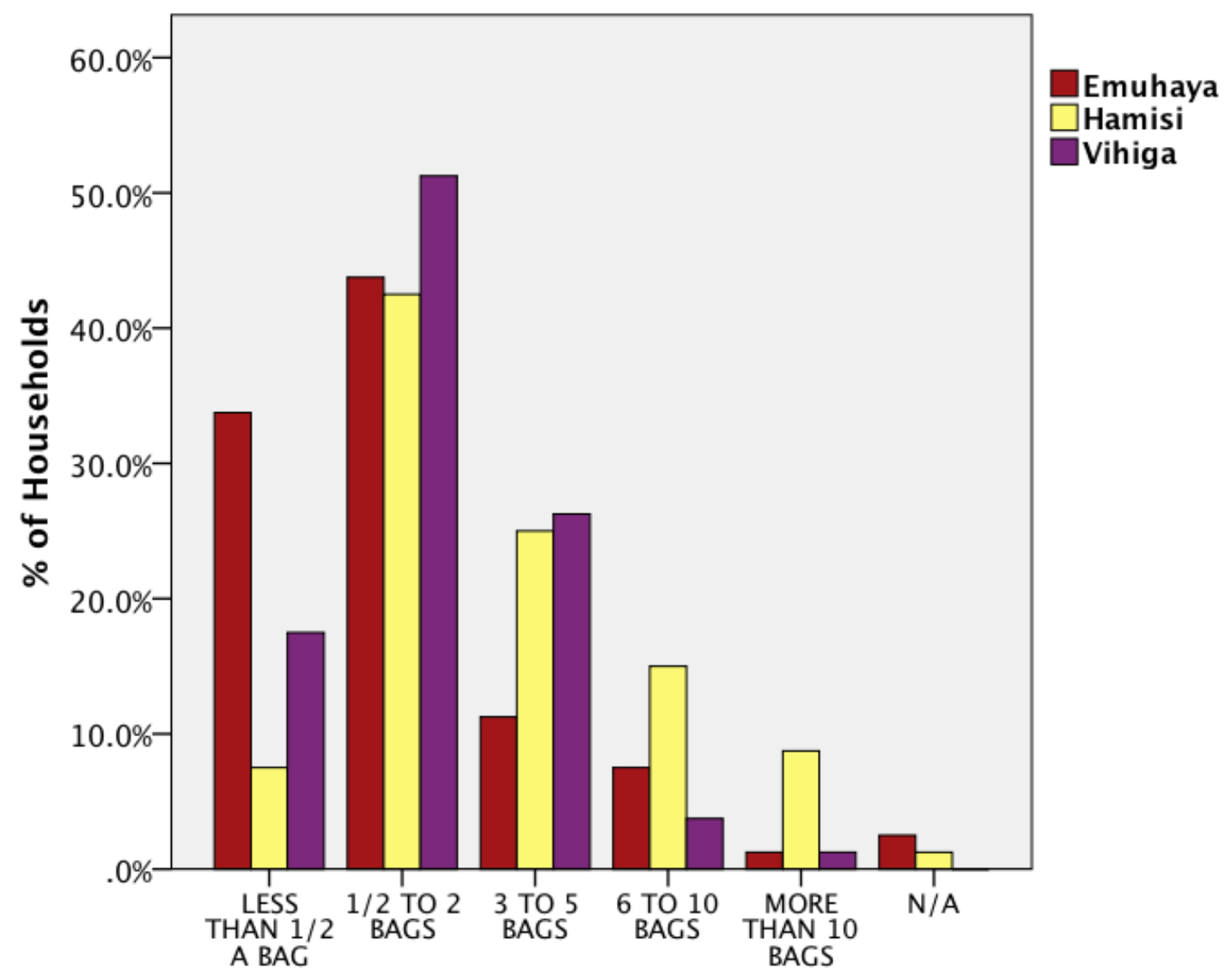

Bags of Maize Harvested in a Good Year

Figure 3.12: Maize Harvest in a Good Year

As the family runs out of maize, they reduce the number of times they eat ugali (staple food made from maize meal) to just once a day with the midday meal being the likely one to be skipped by $55 \%$ of the households. While many of the households tend to rely on eating ugali at both lunch and dinner during times of adequate maize supplies, some better off households seem to have a more diversified diet that includes chapati (a type of flat bread) and rice. They also eat meat, chicken and eggs more often. Contrary to the popularly held notion about women and children eating last or getting smaller food portions during times of scarcity, most of the respondents (90\%) indicated that even when the food is not enough, it is shared equally among members of the household. Over $52 \%$ of the households indicated that they often have just one proper meal in a day - mainly ugali with vegetables in the evening - and there are days when they 
go without eating any proper meal. Fruits like mangoes are only eaten when they are in season and are easily available either on family farm trees or cheaply on the market.

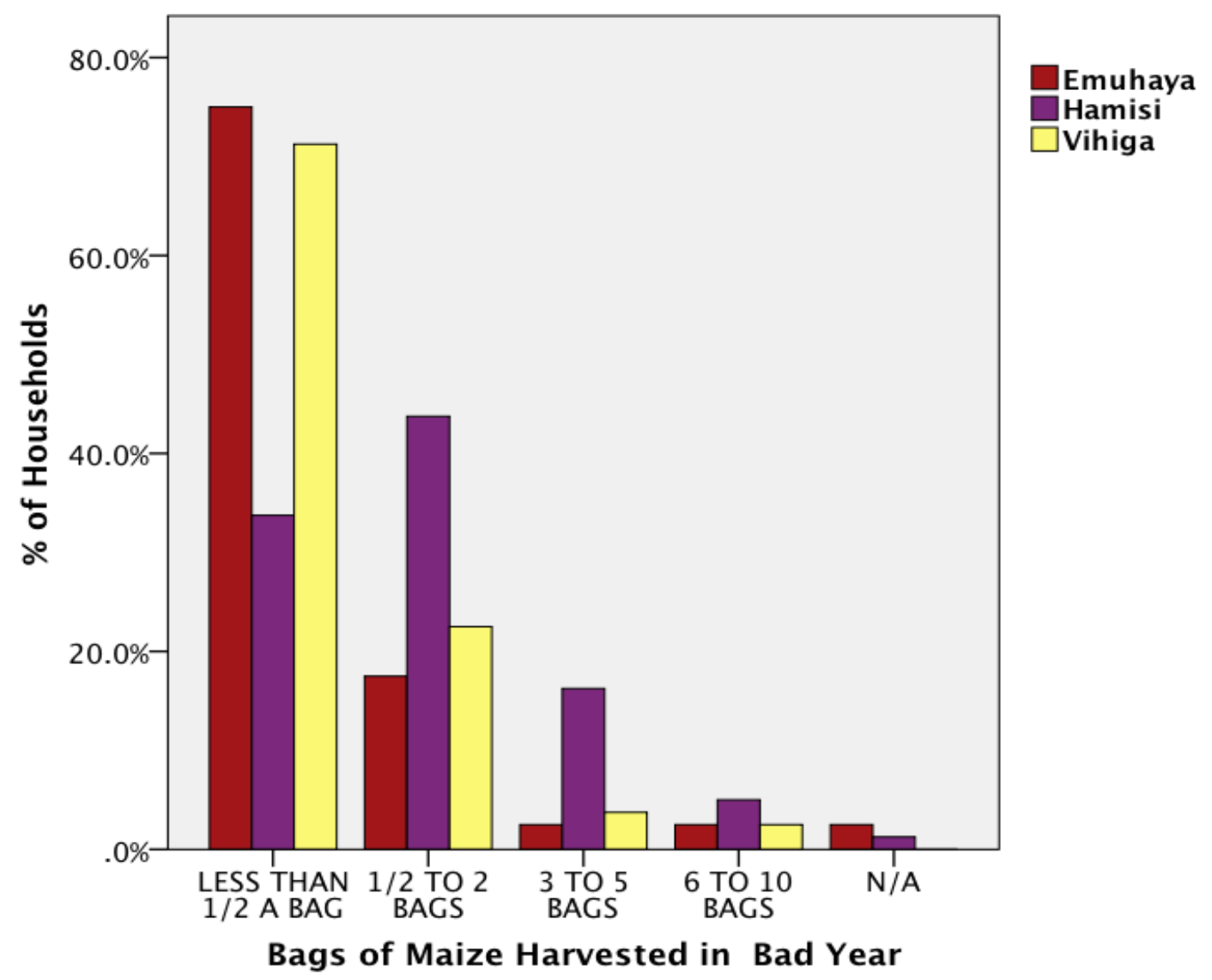

Figure 3.13: Maize Harvest in a Bad Year

The desperation associated with the inability to produce enough food to feed the family is partially to blame for the escalating cases of petty thefts that are now prevalent in the area as noted by local administrators:

This normally affects security-wise... we now have security problems, criminal cases of theft ... petty thefts such as stealing chickens, bananas, sugarcane and even if you plant napier grass someone will steal it and go to sell. (Catherine Makanga, Assistant Chief - Ebunangwe sub location - personal communication)

In response to this trend, the government has intensified police presence in the area by building more police posts and increasing the number of administration police. The 'decentralization' of 
the police force is lauded by local administrators who see it as a positive move in countering petty crime in the villages which they see as being detrimental to local development efforts.

We also have petty theft, stealing bananas, cassava, vegetables, livestock etc. and that discourages many of the farmers. We are trying to tackle that through regular raids with the Administration Police (AP), but someone will fear rearing an animal due to insecurity but if there was security and he is assured that the animal will survive then more farmers will keep dairy animals (livestock).....We have cases of people stealing farm produce from the farms on a daily basis. (Setsi Jiveti, Chief Shaviringa Location - personal communication)

The implication of such an approach to rural security is that the state is keen to protect the interests of those who are doing well, even if it means incarcerating the poor who are seen to be a menace to society. This, unfortunately, reflects the general trends across the country with so many unemployed young people.

\subsection{State Initiatives and Livelihood Strategies}

Over the years, the state in post-independent Kenya has adopted varied strategies in the pursuit for rural development. While most of the proposed strategies had the potential of making a significant positive impact, their implementation was often marred with problems that ranged from lack of funding to corruption. The inevitable outcome is a country that is characterized by immense regional inequalities. When Kibaki's National Rainbow Coalition (NARC) took over Kenya's leadership in 2003, many Kenyans were optimistic that this trend would be addressed as promised. The introduction of the Constituency Development Fund (CDF) was one of the strategies that the Kibaki administration adopted to address the problem of skewed development. Some of the projects implemented under this Fund included paving of roads, renovation of public school buildings, renovation of health facilities and market places. Lay et al (2008) notes that access to community resources such as physical and institutional infrastructure are significant in determining the level of engagement in non-agricultural activities by members of the household. 
More rural development projects were implemented in 2008 through the Economic Stimulus Program (ESP) ${ }^{10}$. Respondents in this study were asked for their perception and/or experiences with selected state sponsored projects and how important they thought the projects were in improving their livelihoods. The results indicated varied perceptions and experiences. Overall, there were positive perceptions of most of the projects with nine of the ten selected projects being viewed as being very important by more than $50 \%$ of the respondents. Fish farming, which was introduced in the area under the Economic Stimulus Projects, was the only project that was not viewed as being very important by a majority of the respondents (Table 6)

Projects targeting the youth such as building and renovating of schools and Kazi Kwa Vijana (Jobs for Youth) ranked highest in terms of importance to the community. However, many of the respondents indicated that they had not benefitted directly from many of the projects. The projects that some of the respondents have benefitted from include the protection of water springs, improvement of schools (since parents no longer have to make regular payments to the local schools for development projects), distribution of farm inputs and improvement of local health facilities.

\footnotetext{
${ }^{10}$ The goal of ESP was to spur the Economic which was on a free fall after the 2007 - 2008 post-election violence
} 
Table 3.6: Local perceptions on the Importance of State - funded development projects

\begin{tabular}{|l|l|l|l|l|}
\hline Project & $\begin{array}{l}\text { Very Important } \\
(\%)\end{array}$ & Important (\%) & $\begin{array}{l}\text { A little important } \\
(\%)\end{array}$ & $\begin{array}{l}\text { Not important } \\
(\%)\end{array}$ \\
\hline $\begin{array}{l}\text { Rural Access } \\
\text { Road }\end{array}$ & 67.5 & 27.9 & 2.5 & 2.1 \\
\hline $\begin{array}{l}\text { Fresh Produce } \\
\text { Sheds }\end{array}$ & 57.5 & 38.3 & 1.67 & 2.1 \\
\hline $\begin{array}{l}\text { Improving of } \\
\text { Health Centers }\end{array}$ & 76.2 & 22.9 & 0.83 & 0 \\
\hline $\begin{array}{l}\text { Improving of } \\
\text { Schools }\end{array}$ & 78.3 & 20 & 1.25 & 0 \\
\hline Fish Farming & 48.8 & 36.7 & 7.1 & 6.7 \\
\hline $\begin{array}{l}\text { Improved variety } \\
\text { Crops }\end{array}$ & 53.8 & 35.4 & 7.1 & 2.9 \\
\hline Farm inputs & 65 & 25.8 & 1.7 & 0.8 \\
\hline $\begin{array}{l}\text { Jobs for Youth } \\
\text { (Kazi Kwa Vijana }\end{array}$ & 70.4 & 24.2 & 5.8 & 5 \\
\hline $\begin{array}{l}\text { Protection of } \\
\text { water springs }\end{array}$ & 69.6 & 27.5 & 2.1 & 0 \\
\hline $\begin{array}{l}\text { Rural } \\
\text { Electrification }\end{array}$ & 55.4 & 38.3 & & \\
\hline
\end{tabular}


Some of the major concerns that area residents have as far as these projects are concerned are poor implementation and governance issues with corruption and clanism ${ }^{11}$ being the biggest problems. Consequently, most of these projects never reach the targeted population. There are also indications that most projects are implemented in a haphazard manner without prior planning and coordination between the various government department and ministries concerned. For some of the agricultural projects, farmers do not receive adequate training and technical support necessary for successful implementation. Some of the projects such as the distribution of free farm inputs were implemented at such small scales that their impact in improving the food security of the majority of the households remained dismal. In spite of these setbacks, area residents expect the government to maintain a proactive role in addressing household poverty by having more projects targeting improving livelihoods such as more inclusive and widespread distribution of farm inputs. The potential of such sectoral interventions in improving and having long term impacts on rural livelihoods however, remains elusive since they are simply stop gap measures that address the symptoms and not the root causes of rural uneven development (Carr \& McCusker 2009)

\section{Discussion}

The results of this study shed light on the processes and relations that define the change trajectory of the livelihoods of rural households in Vihiga. The incorporation of Vihiga into the global economy in the early decades of the 20th $\mathrm{C}$ initiated a host of new relations and processes that set the livelihoods on a different path of change. These new set of relations and processes have over the past one century been central in defining how Vihiga households make a living. It is therefore inevitable that changes within this global economic framework such as the emergence of free market capitalism alter the nature of the processes and relations that shape these livelihoods. The various ways in which livelihoods in Vihiga have evolved are evident in the changes in the diversification options for most of the households.

\footnotetext{
${ }^{11}$ Clanism is a form of local nepotism where project leaders or local administrators tend to favor members of their clan to benefit from projects or government or NGO sponsored aid
} 
Diversification is a central relation and process in rural livelihoods as the opportunities available to the households often determine and are determined by the already existing possibilities. In Vihiga, most of the households are now faced with a shrinking range of possibilities in as far as livelihood diversification is concerned. Some of these factors, such as the declining farm sizes, are socio-cultural, stemming from the cultural practice of sons inheriting land from their fathers. Declining farms imply limited agricultural potential and vulnerability to food insecurity. Similarly, limited access to land implies that most households cannot engage in cash crop production and therefore their income levels remain low. Low income is therefore both a cause and effect of the inability of households to diversify their agricultural activities. This situation has been compounded further by the withdrawal of government subsidies on farm inputs that put them out of reach for poor farmers who desperately need them. Given the level of soil exhaustion in the area due to repeated cultivation, the inability to access such inputs has significant repercussions on the farm output and subsequent food security of the households.

Neoliberal economic policies implemented in the 1990s in the agricultural sector have further compounded efforts by Vihiga households to eke a living from their dwindling farms. The reduction of the budget in the Ministry of Agriculture as part of the rationalization of government expenditure saw cutbacks in agricultural extension staff at the district and divisional levels causing a decline in accessing extension services that rural farmers need. This has had a tremendous impact on productivity as farmers lack the necessary technical support to realize the maximum potential from their small pieces of land.

The high poverty levels in Vihiga have made it impossible for many households to educate their children beyond primary school. The low levels of education make it impossible for youth from this area to be competitive in a cut throat job market. Incidentally, even those who are able to receive a high school diploma and beyond are no longer assured of secure jobs in the formal sector due the high unemployment rates in the country. Unemployed or underemployed family members are unable to regularly send money to their families who have come to depend on such remittances to meet their needs, including sending younger children to school. Hence, low education levels are also both a cause and effect of decline in livelihood diversification options. 
The impact of unemployment on local livelihoods seems to have worsened in recent decades as more avenues for absorbing the youth were taken away in the wake of neoliberal free market policies. The privatization of parastatals saw a significant number of migrant workers return home and try to eke out a living from the tiny parcels of land. One such individual who worked in a textile factory in a nearby town (Eldoret) expressed his frustration as he tried to juggle doing some farming and livestock trading to support his family. He was barely making enough money from both of these to take his children to high school. At the local level, the influx of imported jam saw the local jam and resin factory close down. The people who were affected by this closure included the immediate employees as well as the pawpaw traders who delivered pawpaws to the factory as well as the pawpaw farmers. This diversification failure has led to a livelihood crisis that is evident in such behavior like the rampant petty theft. Households that are pushed to the edge are forced to engage in destructive livelihood strategies that are ecologically unsustainable such as brick-making.

In the face of declining livelihood options, Vihiga residents expect the state to provide some kind of reprieve. However, state funded projects have both constraining and enabling effects on livelihood diversification. For individuals engaging in petty business, better roads mean that they are able to travel to nearby markets faster to purchase the products from middlemen at wholesale price which they resale to make minimal profit. However, good roads also mean that these middlemen are able to move truckloads of goods into the villages and sell them at the wholesale prices to the villagers. This development is evident in maize trading where it is now common to see three of four different truckloads of maize traversing the interior parts of the village on one single day. Most of the maize traders often sell the maize in $90 \mathrm{~kg}$ bags which most households cannot afford. Petty maize traders are therefore still able to survive the competition albeit with fewer potential customers (those who are too poor to afford to buy a $90 \mathrm{~kg}$ bag). The real beneficiaries of the improved infrastructure in rural areas are the large scale merchants who now have access to a larger market for their products. This trend is similar to what Peters (2006) observed in southern Malawi where neoliberal market policies "brought an influx of crop traders into the villages at harvest time" (p. 335). These observations also reflect what Bernstein (2004) refers to as the "risks and opportunities" that neoliberal economic policies 
present for farmers and petty commodity producers in rural Africa who are both "capitalists and laborers".

On the other hand, the provision of health and education services in the County as public goods also serves to improve the quality of "labor reserve" in the County to improve their skills in preparation for work in nearby towns. Government funded projects can also be seen as elements of state redistributions with the tenders for the projects being awarded to the rich and powerful. Very few of the households have the capital to engage in high-return business ventures and therefore don't stand to benefit from better roads. They however provide a ready market for locally manufactured and imported goods. By financing projects that improve infrastructure is facilitating the faster integration of Vihiga into the global economy by "expediting and arbitrating the stable expansion of capitalism" (Smith 2008).

There is a disconnect between the residents' expectations from the government and what the government is focusing in. While numerous government projects have focused on improving infrastructure such as roads and schools, the residents prefer that they received more direct assistance to shore up their livelihoods. "We cannot eat roads", they say. Investments in infrastructure have long term potential benefits yet most households' basic needs of food are not met. The few projects that have focused directly at improving food production such as the distribution of inputs benefit only a few households, in a few of the County's locations. Their implementation is riddled with corruption and "clanism" where, when local administrators are used to identify the neediest households, they start by listing only members of their clan. Needless to say, many needy households are left out of these projects yet they have the potential of making a significant difference on household food security as noted by Peters (2006).

\section{Conclusion}

When the Kenya government began implementing neoliberal economic policies in the 1990s, Vihiga households were already confronted with the challenges of being incorporated in the global capitalist economy. Like many rural agricultural communities in the global South, this incorporation was skewed, favoring a few individuals - the petite bourgeoisie. The 
implementation of neoliberal economic policies made an already bad situation worse reducing the livelihood options that Vihiga households had developed over the years for coping with declining agricultural potential. As a result, these households are now extremely vulnerable, having to rely on the market for most of their needs, a trend that characterizes the urban poor and hence the notion that they are "living like they are in the city".

\section{References}

Barker J. 1989. Rural Communities under Stress: Peasant Farmers and the State in Africa. Cambridge University Press, NY

Barnes T. 2009. "Not Only.... But Also": Quantitative and Critical Geography. The Professional Geographer 61 (3): $292-300$

Bernstein H. 2004. Considering Africa’s Agrarian Questions. Historical Materialism 12 (4): 115 $-144$

Bernstein H. 2007. Capitalism and the Moral Economy: Land Questions in sub Saharan Africa. Paper presented at the Conference on Poverty and Capital, Global Poverty Research Group and Brooks World Poverty Institute, University of Manchester, 2-4 July 2007

Berry S. 1993. No Condition is Permanent: the Social Dynamics of Agrarian Change in sub Saharan Africa. University of Wisconsin Press, Madison, WI.

Bold T., Kimenyi M., Mwabu G \& Sandefur J. 2009. Free Primary Education in Kenya: Enrolment, Achievement and Local Accountability. http://www.iig.ox.ac.uk/output/presentations/pdfs/12a-randomized-eval-policies-kenyapresentation-01.pdf last accessed on March 302013

Bond P. 2008. Accumulation by Dispossession in Africa - False Diagnoses and Dangerous Prescriptions. In Mensah J., Neoliberalism and Globalisation in Africa-Contestations on the Embattled Continent. Palgrave Macmillan, NY.

Bryceson D., Kay C. \& Mooij J. (eds.) 2000. Disappearing Peasantries? Rural Labor in Africa, Asia and Latin America. Intermediate Technology Publications, London.

Bunker S. 1987. Peasants against the State: Politics of Market Control in Bugisu, Uganda, 1900 1983. University of Illinois Press, Urbana, IL. 
Carr E. and McCusker B. 2009. The Coproduction of Land Use and Livelihood Change: Implications for Development Interventions, Geoforum 40: 568 - 579.

Chambers R. 2006. The State and Rural Development: Ideologies and an Agenda for the 1990s. In Behera M. (ed.). Globalizing Rural Development: Competing Paradigms and Emerging Realities. Sage Publications, New Delhi.

Cheong S., Brown D., Kok K. \& Lopez-Carr D. 2011. Mixed Methods in land change research: towards integration. Transactions of the British Geographers 37: 8-12

Conelly W. \& Chaiken M. 2000. Intensive Farming, Agrodiversity and Food Security under conditions of extreme population Pressure in Western Kenya. Human Ecology 28 (1): 19 - 51

Crowley E. \& Carter S. 2000. Agrarian Change and the Changing relationships between Toil and Soil in Maragoli, Western Kenya (1900 - 1994). Human Ecology 28 (3): 383 - 414

Ellis F. 1998. Household Strategies and Rural Livelihood Diversification, Journal of Development Studies 35 (1): 1-38.

Ellis F. 2000. Rural Livelihoods and Diversity in Developing Countries. Oxford University Press, Oxford.

Francis E. \& Hoddinott J. 1993. Migration and Differentiation in Western Kenya: A Tale of Two Sub-locations, Journal of Development Studies 30 (1): 115 - 145.

Francis E. 2000. Making a Living: Changing livelihoods in rural Africa, Routledge, NY.

Githinji M. \& Cullenberg E. 2003. Deconstructing the Peasantry: Class and Development in Rural Kenya, Critical Sociology 29 (1): 67 - 88.

Githinji M. 2000. Ten Millionaires and Ten Million Beggars: A Study of Income Distribution and Development in Kenya. Ashgate, VA.

Harrison G. 2010. Neoliberal Africa: The Impact of Global Social Engineering. Zed Books, London, NY.

Harvey D. 1996: Justice, Nature and the Geography of Difference. Blackwell, Oxford Harvey D. 2006. Neo-liberalism as Creative Destruction. Geografiska Annaler 88B (2): 145 158. 
Hill F. 1978. Experiments with a Public Sector Peasantry: Agricultural Schemes and Class Formation in Africa. In Smith A. \& Welch C. Peasants in Africa, African Studies Association, Brandeis University, Waltham, MA.

Hyden Goran 1980. Beyond Ujamaa: Underdevelopment and the Uncaptured Peasantry University of California Press, Berkeley / Los Angeles USA

Iiyama M., Kariuki P., Kristjanson P., Kaitibie S. \& Maitima J. 2008. Livelihood Strategies, Incomes and Soil Management Strategies: A Case Study from Kerio Valley, Kenya. Journal of International Development 20: 380 - 397.

Johnston R.J., Gregory Derek, Pratt Geraldine and Watts Michael (eds.) 2000. The Dictionary of Human Geography $4^{\text {th }}$ edition, Blackwell Publishers, MA.

Kitching G. 1980. Class and Economic Change in Kenya: The Making of an African Petite Bourgeois, 1950 - 1970. Yale University Press, New Haven, CT.

Knauss P. 1978. Algeria's “Agrarian Revolution”: Peasant Control or Control of Peasants. In Smith A. \& Welch C. Peasants in Africa, African Studies Association, Brandeis University, Waltham, MA.

Kristjanson P., Krishna A., Radency M. \& Nindo W. 2004. Pathways out of poverty in Western Kenya and the role of livestock. Pro-poor Livestock Policy Initiative Working Paper No. 14, International Livestock Research Institute, Kenya

Kwadwo K. 2000. The Best of Times and the Worst of Times: Structural Adjustment Programs and Uneven Development in Africa - The Case of Ghana. Professional Geographer 52 (3): 469 483.

Lay J., Mahmoud T., and M'Mukaria G. 2008. Few Opportunities, Much Desperation: The Dichotomy of Non-Agricultural Activities and Inequality in Western Kenya. World Development 36 (12): 2713 - 2732.

Leichenko R. \& O’Brien K. 2008. Environmental Change and Globalization: Double Exposures. Oxford University Press, New York

Marchand B. 1978. A Dialectical Approach in Geography. Geographical Analysis (2) Maxon R. 2003. Going their separate ways: Agrarian Transformation in Kenya 1930 - 1950. Fairleigh Dickinson University Press, London. 
McHenry D. 1978. Peasant Participation in Communal Farming: The Tanzanian Experience. In Smith A. \& Welch C. Peasants in Africa, African Studies Association, Brandeis University, Waltham, MA.

Mensah, J. (ed.). 2008. Neoliberalism and Globalization in Africa: Contestations on the Embattled Continent. Palgrave Macmillan.

Moseley W., Carney J. and Becker L. 2010. Neoliberal policy, rural livelihoods, and urban food security in West Africa: A Comparative Study of the Gambia, Cote d'Ivoire and Mali.

Proceedings of the National Academy of Sciences 107 (13): 5774 - 5779.

Neves D. \& Du Toit A. 2013: Rural Livelihoods in South Africa: Complexity, Vulnerability and Differentiation. Journal of Agrarian Change 13 (1): 93 - 115.

Nkwota O. \& Ochieng G. 2009. Water Pollution in Soshanguve Environs of South Africa. World Academy of Science, Engineering and Technology 56: 499 - 503

Oberhauser A. 2010. (Re)Scaling Gender and Globalisation: Livelihood Strategies in Accra, Ghana. ACME: An International E-Journal for Critical Geographies 9 (2): 221 - 244.

Ollman B. 2003. The Dance of the Dialectic: Steps in Marx's Method. University of Illinois Press. Urbana, IL.

Ollman, B. 1993. Dialectical investigations. Routledge, London.

Orvis Steven 1997. The Agrarian Question in Kenya. University Press of Florida, Gainesville, FL.

Oya C. 2007a. Stories of Rural Accumulation in Africa: Trajectories and Transition among Rural Capitalists in Senegal. Journal of Agrarian Change 7 (4): 453 - 493.

Oya C. 2007b. Agricultural Maladjustment in Africa: What have we learned after two decades of Liberalization. Journal of Contemporary African Studies 25 (2): 275 - 297.

Peet R. 2003. Unholy Trinity: The IMF, World Bank and WTO. Zed Books Peters P. 2006. Rural Income and Poverty in a time of Radical Change in Malawi. Journal of Development Studies 42, 2: 322 - 345.

Place F., Adato M. and Hebinck P. 2007. Understanding Rural Poverty and Investment in Agriculture: An Assessment of Integrated Quantitative and Qualitative Research in Western Kenya. World Development 35 (2): 312 - 325. 
Sandbrook R. 2005. Africa's Great Transformation. Journal of Development Studies 41 (6): 1118 $-1125$.

Shanguhyia M. 2007. The State, Ecology, and Society in Western Kenya: Politics of Soil Conservation and Land Management in Vihiga, 1930 - 1950. PhD. Dissertation West Virginia University

Sheppard E. 2008. Geographical Dialectics? Environment and Planning A 40: 2603 - 2612. Sorrenson M. P. K. 1967. Land Reform in Kikuyu Country, Oxford University Press, Nairobi, Kenya.

Sui D. \& DeLyser D. 2012. Crossing the qualitative chasm I: Hybrid geographies, the spatial turn and volunteered geographic information (VGI). Progress in Human Geography 36 (1): 111 - 124

Swallow B. 2005. Potential for Poverty Reduction Strategies to Address Community Priorities: Case Study of Kenya. World Development 33 (2): 301 - 321.

Thorner D, Kerblay B. \& Smith R. E. F (eds.) 1966. A.V. Chayanov on the Theory of peasant Economy. Richard Irwin for The American Economic Association, Homewood, IL.

United States Agency for International Development (USAID)- Kenya Economic Growth, http://kenya.usaid.gov/programs/economic-growth Last accessed on Nov 19th 2012

Vihiga District Annual Agricultural Report 2008

Vihiga District Annual Report 1996

Wakwabubi E. 2006. Engendering Participatory Development in the Analysis of Household Food Security: Small Scale Farmers in Vihiga District of Kenya. In Behera M (ed): Globalizing Rural Development: Competing Paradigms and Emerging Realities. Sage Publications, New Delhi.

Walingo M. K. 2008. Health and Nutrition Effects of Poverty Reduction Strategies in Vihiga District, Kenya. In Veritta L (ed.) Poverty Alleviation: 21st Century Issues and Challenges. Nova Science Publishers, NY.

Watts M. 1989. The Agrarian Question in Africa: Debating the Crisis. Progress in Human Geography, 13:1.

Welch Claude Jr. 1978. Peasants as a Focus in African Studies. In Smith A. \& Welch C (eds.) Peasants in Africa. African Studies Association, Brandeis University, Waltham, MA 
Yeager C. \& Steiger T. 2013. Applied geography in a digital age: The case for mixed methods. Applied Geography 39: 1- 4

Zolnik E. 2009. Context in Human Geography: A multilevel Approach to Study HumanEnvironment Interactions. The Professional Geographer 61 (3): 336 - 249 


\title{
Chapter 4
}

\section{Capital Penetration, Commodification of Nature and the Production of Rural Space: Examining Land Use and Land Cover Change in Western Kenya}

\begin{abstract}
This study examines the spatial dimensions of rural change over a 25 year period of neoliberal economic change, from the vantage point of land use and land cover change. The analysis combines social and spatial methods to and draws from Neil Smith's and David Harvey's political economic theory to examine the production of nature and space on a rural landscape in western Kenya. Change detection done using Landsat imagery indicates some changes that include simultaneous loss and regeneration of forest cover and expansion of road infrastructure. Other observed changes include a horizontal and vertical expansion of peri-urban centers. These landscape changes reflect on-going processes of enhanced penetration of capital and commodification of nature that are associated with neoliberal economic change.
\end{abstract}

\section{Introduction}

There is a general consensus in studies on rural Africa that the past three to five decades have been marked with rapid transformations that are associated with global economic and environmental change. A significant number of these studies focus on changes in the livelihoods of rural households in sub Saharan as one of the tangible and observable ways that is indicative of the broader changes taking place (e.g. Berry 1993, Bryceson 2000, Ellis 2000, Neves \& Du Toit 2013, Peters 2006). These studies highlight the dynamics that shape and define the changes in rural livelihoods that include but not limited to economics, politics, society and the environment. A major underlying theme in these studies is that demographic pressure, economic shifts and environmental change have made agrarian based livelihoods unviable (Bryceson 2000). While a lot of attention has focused largely on the different dimensions of livelihood change, the spatial implications of this change have remained peripheral and have not been fully integrated in most of the analyses. King (2011) notes that this approach downplays the spatial dimensions of 
rural change and argues that "production and reproduction of livelihoods are linked with the processes producing and reproducing space" (p. 297).

This study examines the spatial dimensions of rural change over a 25 year period of rapid economic transformations, from the vantage point of land use and land cover change. Such an analysis is essential for a broader and holistic understanding of rural change. Marsden (1995) noted that " a focus on uneven development is central in linking more effectively the social and the spatial, and in understanding the changing face of rural space" (p. 285). This is especially important considering that livelihoods are spatial in the sense that the activities that different members of the household members undertake in making a living are embedded in space as King (2011) notes, "spatializing livelihoods reveals the household to be the dynamic unit that is not bound in space and time" (p. 309), while McCusker \& Carr (2006) argue that "livelihood and land use changes are co-produced where shifts in one are reflexive of shifts in the other" (p. 791). This underscores the necessity of a dialectical reading that engages with the socio-spatial nature of rural change. Such an approach views livelihoods and land use as two of the diverse vantage points from which rural change can be viewed and not just as two of the myriad processes that are interacting in causal relationships.

\section{Political economy of land use}

The analysis adopted in the study of the socio-spatial nature of rural change draws from political economy theory (more specifically from Neil Smith and David Harvey) and land use and land cover change literature. Within this approach, the landscape is viewed as a mosaic that reflects the numerous ongoing change processes. This approach has theoretical grounding in the production of nature and production of space theses (Smith 2008, O'Keefe \& Smith 1980, Harvey 1996) that are based on a Marxian interpretation of the "metabolic interaction" between nature and society that presupposes a unity rather than a duality. Smith (2008) notes that with the accumulation of capital and economic development, differentiation in the "material substratum" on landscapes is more societal than natural. This process of differentiation is rooted in the production process, where through production for exchange as opposed to production for consumption human beings expend their labor, thus opening up avenues for connecting with other 
groups of people through institutions such as markets thus fusing together space and society. Smith (2008) links this development to the initial process of surplus production which, having begun as a means of "emancipating" man from nature ends up being the source of differentiation that enslaves a "large part of the population" (p. 59). This process leads to the division between agriculture and commerce and hence the separation of town and country, urban and rural.

With the change in the division of labor also comes change in social relations with implications on human nature:

With production for exchange, the production of nature takes place on an extended scale. Human beings not only produce the immediate nature of their existence but produce the entire societal nature of their existence. They develop a complex differentiation in the relation with nature differentiated according to sex and class, mental and manual activity, production and distribution activities and so on. (Smith 2008, p. 65)

The production of nature is accompanied by the production of space where space and society are also viewed as a unity rather than as a duality. Smith argues that "we do not live, act and work 'in' space so much as by living, acting and working we produce space” (p. 116). Space, in the capitalist mode of production is more relative than absolute. Capitalism as a mode of production requires that wage laborers, alienated from their means of production are free to move to other locations and so is the movement of capital. Harvey (1996) notes that since 1970, the process of capital accumulation has radically altered space-time relations where improvements on communication and transport technology have "made production, merchanting, marketing and particularly finance capital much more geographically mobile" (p. 297).

According to Harvey (2001) the contradictions of capitalism as a mode of production are "worked through and embedded in the production of the geographical landscape" (p. 27). The production and reconfiguration of space are important dimensions in the political economy of capitalism because capital accumulation takes place in a geographical context, resulting in specific kinds of geographical structures (Harvey 2001). Consequently, landscape transformations that occur when investments are fixed spatially and embedded in land are characteristic of what Harvey calls the "spatial fix" - where capital is seeking new spaces for accumulation. When applied to rural environments, this process can be seen and understood by examining a number of processes such as the trends and patterns of built environment that 
facilitates capital accumulation such as improvements in infrastructure and extensions of markets, the changes in the types of crops grown in response to local, urban or global market demands, and the changes in the 'natural' environment such as forests in response to capital.

This chapter uses Vihiga County in Western Kenya as a case study of the production of space and nature in rural environments in a period of neoliberal economic change. While acknowledging the organic and historical nature of change, the study focuses on the changes that have occurred in the past three decades. Numerous studies indicate that this period was marked with major socio-economic and ecological transformations that can be linked to the adoption of neoliberal economic policies that were implemented in most African countries through the Structural Adjustment Programs under the watchful and "expert" guidance of the World Bank and the IMF (e.g. Moseley et al. 2010, Jansen et al. 2008, Peters 2006). Monitoring changes in land use and land cover is critical to the understanding of the movement of capital and the spatial dimensions of development. Akram-Lodhi (2007) refers to this process as a form of neoliberal enclosure where capital is perpetually seeking to "promote deeper capitalist transformation of societies in the South" with the objective of "deepening the already prevailing set of capitalist social property relations" (p. 1446). Forms of neoliberal enclosure include export oriented agricultural production that is the mainstay of Kenya's economy (as well as many other countries in the global South). This kind of market oriented production is indicative of capital seeking to "colonize" new frontiers (ibid). In rural parts of sub Saharan Africa that are already embedded in the global economy either directly or indirectly, visual representations of the patterns depicted in land cover can reveal such frontiers for capital penetration and the various forms of neoliberal enclosure.

\section{Land use and land cover change}

The use of satellite imagery to study changes in land use and land cover in sub Saharan Africa has become more prolific and widespread (Brink \& Eva 2009, Cihlar 2000, Jensen et.al. 2006, Kamusoko \& Aniya 2009, Kiage et.al. 2007, Lambin 2003, McCusker 2004, Rindfuss et. al. 2003, Shalaby \& Tateishi 2007). This trend can be attributed to the enhanced availability of satellite imagery with higher spectral, spatial and temporal resolutions and to the growing trend of 
integrating social and spatial data within human- environment research. This is enhanced by the fact that monitoring and documenting land use and land cover changes in Africa is now acknowledged as an important dimension in addressing key development issues such as sustainable food production, forest and fresh water resources, climatic changes and human welfare (Brink \& Eva 2009).

Studies that use remote sensing to examine land use change in Africa can be broadly categorized into two: those that focus on the biophysical aspect of the change process (e.g. Brink \& Eva 2011, Brink \& Eva 2009, Kiage et.al. 2007, Lung 2006, Landman et.al. 2010, Boakye et. al. 2008) and those that focus on linking the biophysical process to broader social, economic and political processes (e.g. Jensen et.al. 2006, Lambin 2003, McCusker 2004, Campbell et.al. 2005, Moore et. al. 2012). The former category focuses on explaining the nature of biophysical changes that have occurred in a given place for a given period of time. The scale and scope of such studies is varied. For instance Kiage et al. (2007) used Landsat TM and ETM+ imagery to study the changes that had taken place in the Lake Baringo catchment area over a 14-year period and the effects of these changes on sedimentation in the lake while Brink and Eva (2009) used Landsat MSS, TM and ETM imagery to examine changes in sub-Saharan Africa's natural land cover resources over a 25 -year period. Studies in the latter category tend to use remote sensing alongside other social research methods such as household surveys and interviews to explain the causal connections between the two. For instance McCusker (2004) used remote sensing and GIS techniques alongside household surveys and qualitative interviews to study the impact of South Africa's land reform program on land use change in rural areas of Limpopo province. Similarly, Lambin (2003) combined remote sensing and socio-economic household survey data to examine the underlying processes of land use change in southern Cameroon and in the Maasai Mara Natural reserve in Kenya. These studies, which fall in the broader subfield of political ecology examine land use and cover, their processes of change and sustainability "with an emphasis on informing development especially in regard to improved well-being among disadvantaged people" (Turner \& Robbins 2008, p.308)

More recently, the use of remote sensing techniques to inform intervention programs for food security and health issues has gained widespread application. Programs that monitor the conditions that contribute to the chronic food crises in many parts of the continent such as the 
United States Agency for International Development's (USAID) Famine Early Warning Systems Network (FEWS NET) use remote sensing data alongside other social economic indicators to identify potential hotspots and vulnerable populations. The observations that are made through remote sensing are useful in informing explanations of causal relationships and processes that give rise to these situations (De Fries et. al. 2006, Moore et.al. 2012).

One of the challenges of studying land use and land cover change in Africa is the ability to get imagery that accurately captures the changes that have occurred. Much of this change occurs at significantly smaller spatial and temporal scales. Imagery of higher spatial resolution such as IKONOS, Quickbird and SPOT is the most appropriate for studying such changes but the cost of such imagery remains prohibitive. Furthermore, the lack of historical imagery of similar resolution that is required for change detection analysis implies that the uses of such high resolution imagery are very limited. With adequate ancillary data, though, change detection can be effectively carried out using Landsat images (Kiage et.al. 2007; Kamusoko \& Aniya 2009; Dewan \&Yamaguchi 2009). The advantages of using Landsat imagery are numerous. Of most importance, however, is the long temporal record as well as the large spatial extent that is covered. Unfortunately, this spatial extent implies that Landsat imagery has a coarse spatial resolution compared to other imagery such as IKONOS or QuickBird. Furthermore, land cover change detection using satellite alone says very little about the nature of the underlying processes that are causing the change to occur and hence the need to use social data.

One of the major challenges facing land use/cover change researchers is how to integrate spatial and social data (Smucker et.al. 2007, Rindfuss et.al. 2003, Vasquez-Leon \& Liverman 2004, Wood \& Skole 1998, Walsh et.al. 2003). This emanates from the fact that these two types of data are recorded and presented in very different formats and the lack of direct links in the way remote sensing data is recorded to the complex nature of social processes (Crews \& Walsh 2009). A major fundamental decision that has to be made is whether to start with the social processes (people) or with the spatial data (pixels) and the potential implications to the outcome of the investigation (Rindfuss et al. 2003). Crews \& Walsh (2009) propose the adoption of the scalepattern-process framework (used in landscape ecology) where the scale of the imagery chosen will determine the observable patterns from which underlying processes can be inferred. Hence, 
the spatial, spectral and temporal resolutions of the imagery chosen will directly influence the questions being asked or vice versa depending on which end the researcher chooses to start with.

Walsh et.al. (2003) conducted a household survey in Ecuador and linked the data to Landsat TM imagery and aerial photography through the use of survey maps, sketch maps, and GPS. The authors dealt with the challenge of linking "multiple responses to one location" described as a "many-to-one" problem through the use of GIS software. Analysis was conducted to aggregate all responses in a subdivided plot back to the original unit (Walsh et.al. 2003: 106) while the use of GPS provided co-ordinate data and the sketch and survey maps helped untangle the "many-to-one" issue in the GIS database. Without them, it is unlikely that an accurate database could have been created in this case. Using pattern metrics, the authors were able to answer the question, "At what spatial units (e.g. households or communities) or environmental units (e.g. hill slopes or watersheds) influence the composition and spatial structure of the landscape through LCLUC?” (p.115). Using printed map products, Rindfuss, et. al. (2003) conducted group discussions to identify users of particular plots. This clarified the users of plots for comparison with household responses.

In this study, social and spatial data were used in a complimentary way to examine the underlying processes that define the tangible outcomes that are visible on the landscape. Starting with the Landsat imagery of the study area, specific areas of interest showing significant changes in land cover were identified. Administrative locations in which these areas fall were then purposely selected after which households in these locations were then randomly selected for inclusion in the study for surveys and interviews. Information obtained from these interviews and surveys was necessary to explain the observed land cover changes.

\subsection{Land use and Cover Change in Vihiga County}

Vihiga County in western Kenya has some of the highest population densities in the country averaging 1200 persons per square kilometer. The County covers an area of $563 \mathrm{~km}^{2}$ 
with a total population of 554,622 of which $41.8 \%$ are subsisting below the poverty line ${ }^{12}$ (Kenya County Fact Sheet). Dwindling sizes of landholdings have spurred agricultural intensification and extensification as well as livelihood diversification into off-farm activities (Crowley \& Carter 2000, Connelly \& Chaiken 2000, Walingo et. al. 2009). Located in the Lake Victoria basin, this region experiences reliable bimodal rainfall that sustains agriculture. However, recent studies have reported significant reduction in the area's precipitation that is evident in Lake Victoria's receding shoreline, unreliable rainfall and prolonged dry spells (Awange et. al. 2008, Odada et. al. 2009, Walingo et. al. 2009).

Though predominantly rural, a significant majority of the County households do not rely solely on agriculture for a living, reflecting Bryceson's "deagrarianization" thesis. A drive along the major highways that pass through the county shows that the landscape is predominantly made of small (in some cases hedged in) agricultural farms dotted with tin roofed houses with each house often representing a single household of four to six people. In some parts of the county such as Vihiga and Emuhaya districts, the houses are so close together, the roofs are almost touching. On these small plots, households practice a form of seasonal, rain-fed, mixed subsistence farming (mostly maize and beans) with a few engaging in some form of cash crop production (mainly tea) and some agroforestry. Other commonly grown crops include sweet potatoes, bananas, vegetables, millet, cassava, sorghum and napier grass.

Vihiga receives bimodal rainfall with long rains coming in March - June and the short rains in August to November and most of the seasonal crops are two growing seasons that coincide with the rainy seasons. Aggressive campaigns by governmental and non-governmental agencies to promote agroforestry have been quite successful as most of the river valleys are now covered with trees. Most farmers choose to plant the faster maturing eucalyptus species with prospects of quicker returns. More recent campaigns are now encouraging farmers to plant indigenous tree species that do not deplete the underground water sources.

In the southern parts of the county that fall in Emuhaya and Vihiga districts, along the Kisumu- Busia and Majengo-Luanda roads, small farms give way to a hilly and rocky terrain

\footnotetext{
${ }^{12}$ In Kenya, the poverty lines for rural and urban areas are defined separately. In 2005, the poverty line was set at Kshs 1,560 and 2,930 per month for rural and urban areas respectively.
} 
that shows some houses hanging precariously or wedged between rocks, an indication of the prevailing land scarcity in this area. As one moves along the Chavakali - Kapsabet road towards the north-eastern part of the county, they encounter the Kibiri forest, which is the southern tip of the larger Kakamega forest, the only remaining rainforest in Kenya (Peltorinne 2004). This forest is home to indigenous tree species such as elgon teak, red stinkwood, and African satinwood. In recent years though, parts of this forest have been cleared to give room for exotic trees such as pine and cypress which are planted by the Forest department for commercial purposes.

Strategically located along the main roads are market centers such Mbale (the presumed County seat), Majengo, Luanda, Chavakali, Shamakhokho and many more that are abuzz with varied commercial activities (see Appendix A showing the road network). Most of them have evolved from small market centers that in the past had only one or two designated market days in a week to fully fledged peri-urban centers that are rapidly expanding to meet the needs of the local communities and are busy all days of the week. These centers provide a variety of services for the County residents that include banking, internet, schools, transportation and housing as well as services provided by state departments that are located at several centers. According to the 2009 National Census report, $31.4 \%$ of the total County population resides in these peri-urban centers.

\section{Methods}

This study combined spatial and social methods approaches to examining landscape change. The socio-economic data used in this study was collected and analyzed using quantitative and qualitative approaches outlined in Section 4 of Chapter 3. The acquisition and analysis of spatial data is outlined in this section. Analysis of the spatial and social data draws from Ollman's (1993) and Harvey's dialectics where attempts are made to identify the underlying social process that are reflected in the observed material change. This approach is based on a Marxian ontology as interpreted by Ollman where reality is viewed "as a totality that is composed of internally related parts and these parts are expandable such that each one in the fullness of its relations can represent the totality" (p. 78). In this case land use and land cover change is viewed as a totality in itself that is comprised of multiple relations and also as a part of a larger totality 
that is rural change. The following section describes the stages of acquiring and processing the spatial data to detect changes in land use and land cover.

\subsection{Data Acquisition}

This initial step of the change detection process entails obtaining the appropriate imagery for the task at hand. The imagery that is selected for any project needs to have appropriate spectral, radiometric, spatial and temporal properties for the given task (Warner et al. 2009). Change detection can either be bi-temporal - where imagery from the same location taken at two different dates is compared for changes that could have occurred during that period or multi temporal - where the imagery for multiple dates is compared for changes that could have occurred over two or more time periods. Depending on the phenomenon under investigation, the length of the duration or period under investigation needs to be sufficient for the optimum registration of the observable change. In order to minimize on the effects of seasonal changes, phenological differences and the effects of sun angle, the imagery chosen needs to have been acquired on anniversary or near anniversary dates (Coppin et al. 2004; Lu et al. 2004; Warner et al. 2009). However, obtaining imagery that meets this requirement and which is also cloud free for many parts of sub Saharan Africa is a challenge. In their study of land degradation in the Lake Baringo water catchment in Kenya, Kiage et al. (2009) had to settle for data that was acquired during the dry season at the risk of losing distinct spectral signatures between certain classes of land cover.

One of the issues in data selection that continues to draw a great deal of concern is the use of data acquired by multiple sensors. The need to normalize data acquired from similar sensors is important "to ensure that the differences identified in the images are a result of the differences in the scene and not differences in the image properties" (Warner et al. 2009: 461). Combining imagery from different sensors is necessary in cases where the period under study falls outside the lifespan of a specific sensor (ibid). In such a case, the different spectral, spatial and radiometric properties of the different images have to be put into consideration because they have a major effect on the outcome of the change detection process (Lu et al. 2004). In cases of historical land use studies that include pre-satellite era, a combination of aerial photographs and satellite imagery 
is used and this kind of study poses a different kind of challenge because of the differences in spatial and spectral resolutions as well as radiometric responses between these two types of imagery. Petit \& Lambin (2000) developed a method for integrating such imagery through map generalization - a method that equalizes the thematic content and level of spatial detail to create a time series of land cover maps that are comparable.

Knowledge of the phenological information of the different types of vegetation is critical for identifying the most appropriate dates to collect data for remote sensing (Jensen et al. 2006). There is also a crucial need to identify and collect ancillary and reference data to be used in classification of the imagery and for accuracy assessment. The ideal reference data should be acquired at the same time with the imagery that is used. Most historical land use change studies rely on aerial photographs, historical photos and topographic maps. However, such data is not easily accessible in most African countries due to a number of reasons including government bureaucracy to limited resource being directed to mapping and survey programs.

The Landsat imagery that was used for this study was obtained from the United State Geological Survey Global Visualization Viewer (USGS Glovis). Landsat TM images (WRS 2 Path 170, Row 060) were obtained for January 16, 1985 and December 23, 2010 while a Landsat ETM+ image was obtained for February 5, 2001. These images were considered appropriate because they were acquired during the dry season that runs from December to March in this area. This period also marks the pre-planting season in preparation for the long rains (March to May) planting and therefore the potential for distinguishing perennial cropland from seasonal cropland is higher. Ancillary data included topographic maps of the area that were created in 1970 and revised in 1981, aerial photos taken in 1978 and 1972 and over 100 GPS points collected at specific points of interest across the County that included road junctions and market centers.

\subsection{Preprocessing}

This step in the process involves geometric correction and radiometric normalization so as "to present the data in a format from which accurate land cover information can be extracted" (Cihlar 2000, p.1097)). The decision as to whether and how these two steps are done depend on the overall goal and the kind of data obtained. Geometric co-registration of the imagery onto a 
common projection map is a necessary and crucial step in change detection analysis. Registration errors are likely to cause more false changes in a spatially heterogeneous landscape (Warner et. al. 2009). On the other hand, the decision to perform radiometric normalization depends on the kind of change detection methods that are used. For instance Kamusoko \& Aniya (2009) did not perform atmospheric correction on the Landsat imagery they used in their analysis of land use/cover change of Bindura - Zimbabwe because the hybrid classification technique that they used compensates for variation in atmospheric conditions and vegetation phenology between the dates. Kiage et.al. (2007) on the other hand performed radiometric calibrations where original brightness values were converted into surface reflectance to minimize errors. In their attempt to classify agricultural land cover in two areas in South Africa, Jensen et.al. (2009) tried out numerous classification algorithms with original brightness values and with the same data scaled to percent reflectance. This radiometric calibration experiment found classifications based on perfect reflectance data to be more accurate than those based on original brightness values.

For this study, the three Landsat images were preprocessed by performing geometric correction and registering them to a common UTM projection. First the 2010 TM image was georeferenced using GPS points collected during the fieldwork to create a "master" image which was then used to perform geometric correction on the 2001 ETM and 1985 TM images. Subsequently, the images were subset using a shapefile of Vihiga County as the AOI (Fig 4.1). 
a.)

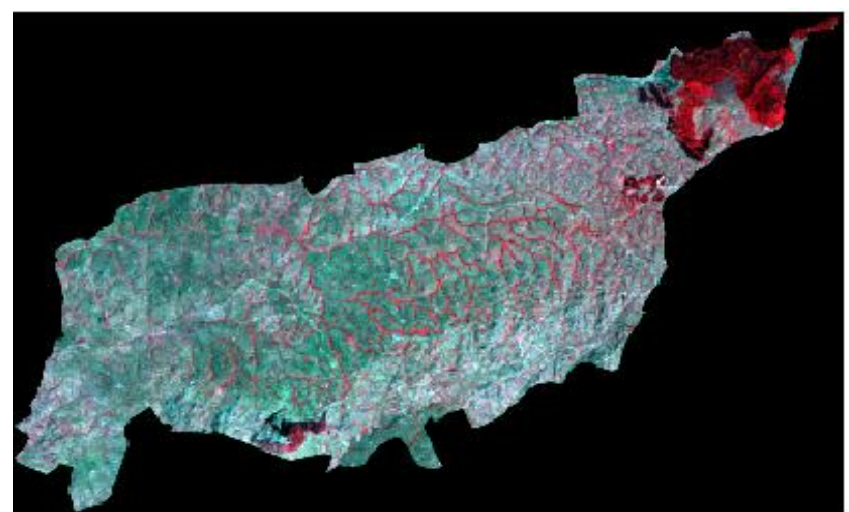

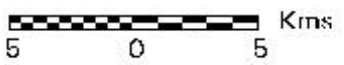

c.)

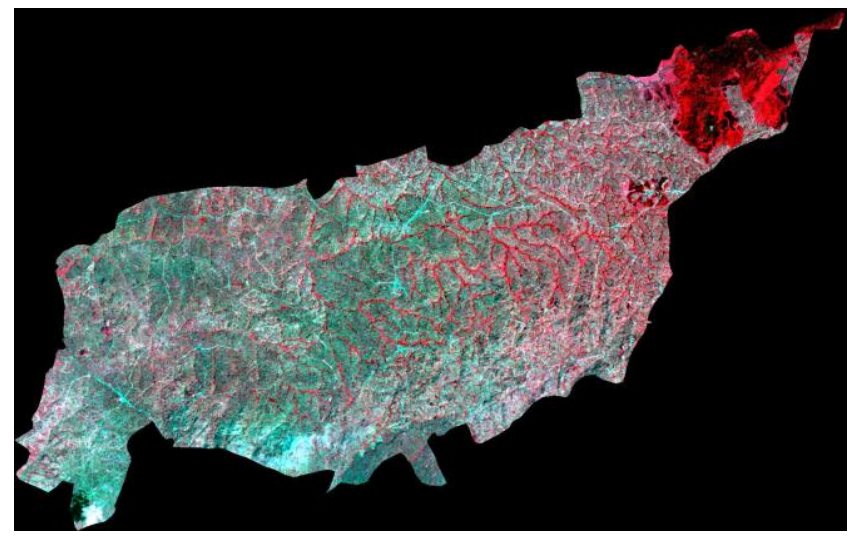

Figure 4.1: False Color composties of Landsat Images of Vihiga County with Bands 4, $3 \& 2$ as Red, Green and Blue, a.) 1/16/1985, b.) 2/5/2001 7 c.) 12/23/2010

The accuracy of the outcome of the change detection process largely depends on the accuracy of the image classification process because errors made in the classification process are magnified in the change detection process (Coppin et. al. 2004). The two commonly used classification techniques are supervised and unsupervised classification. The challenge during this stage is the ability to identify a technique that will adequately isolate between the different classes of interest. Processes such as crop identification may require data of very high resolution which may not be easily accessible for many parts of the continent. In heterogeneous landscapes that are common in rural Africa, spectral confusion is a major problem that has to be dealt with. In Kamusoko \& Aniya's (2009) study of Bindura district in Zimbabwe, settlement areas were 
erroneously classified as agricultural areas and vice versa and hybrid classification - combined supervised and unsupervised classification - was used to solve the problem.

A fairly good understanding of the phenology of the different crops in the area is necessary for classification, but this may not work for all the types of crops. For instance crops like sugarcane can be planted all year round in subtropical environments and therefore different plots may not be at the same phenological stage at all times (Jensen et.al. 2006). Furthermore most household farms in many parts of rural Africa do not have defined shapes and may therefore present a challenge when it comes to classification (McCusker 2004).

In this study, supervised classification was carried out using the maximum likelihood classifier as outlined by Lillesand et.al. (2008, p. 547 - 568). Supervised classification is an efficient and appropriate way to classify imagery when the researcher has prior knowledge of the study site. This type of classification relies on such knowledge to identify training data or signatures that are representative of the different land use/cover classes (Warner et.al. 2009). A total of four land use/cover classes were identified: forest cover, agriculture, water and bare rock/settlement. The agricultural land class was classified further into two informational classes: Agriculture I consisting of seasonal cropland which is bare at this time of the year and Agriculture II consisting of perennial crops like tea and farm trees and therefore spectrally distinct from the bare cropland. The forest class included the areas with mature forest cover while the bare rock and settlement areas included roads, market/peri-urban centers and areas covered in rocks. The three informational classes the latter class were merged into one class due to the spectral similarities that made it impossible to separate them during the classification process. The problem of spectral confusion between urban areas and bare/barren land is typical with studies of this nature (Forkuor \& Cofie 2011). As many as ten training areas were digitized for each of the five land cover classes to capture the spectral variability within each class. Training for classification was done separately for each of the three images, yielding three land cover maps (Figs. 4.2a, 4.2b \& 4.2c). 


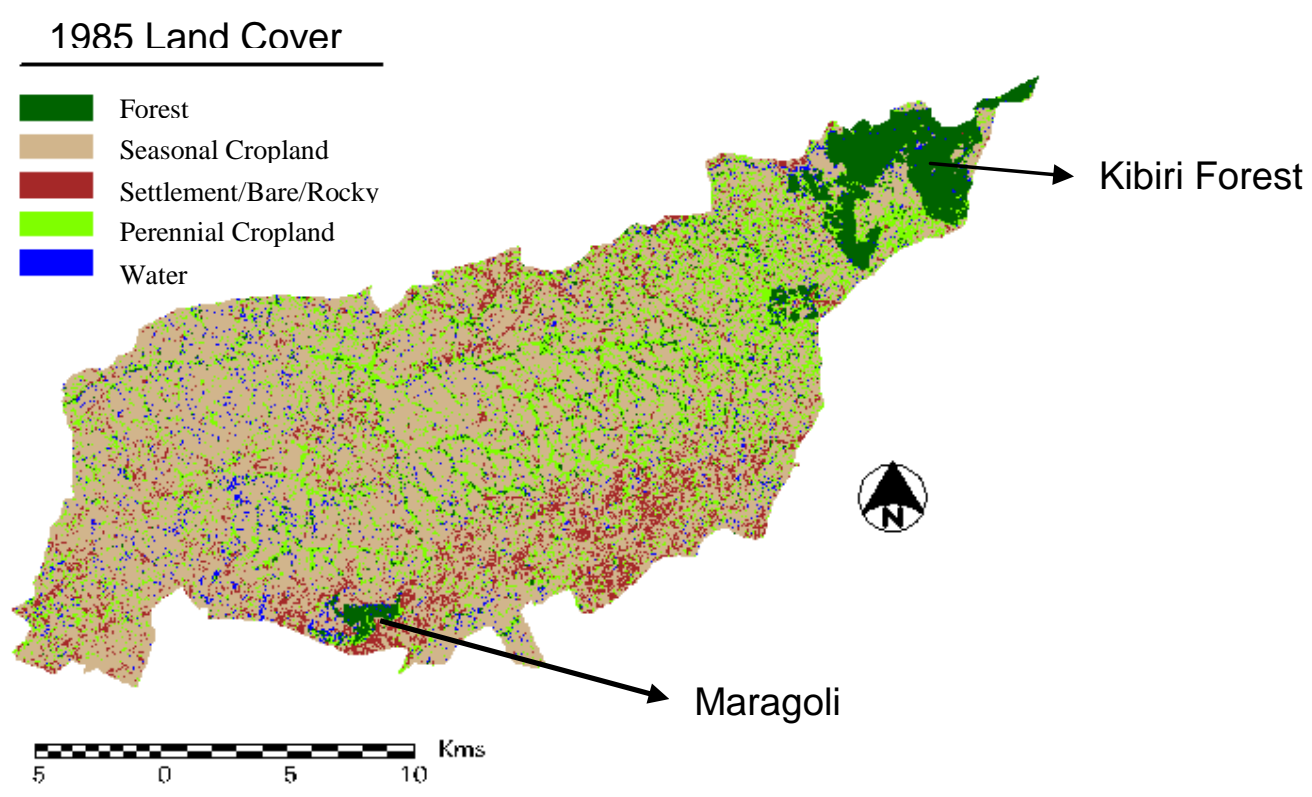

Figure 4.2a: Land Cover Map for January 16, 1985

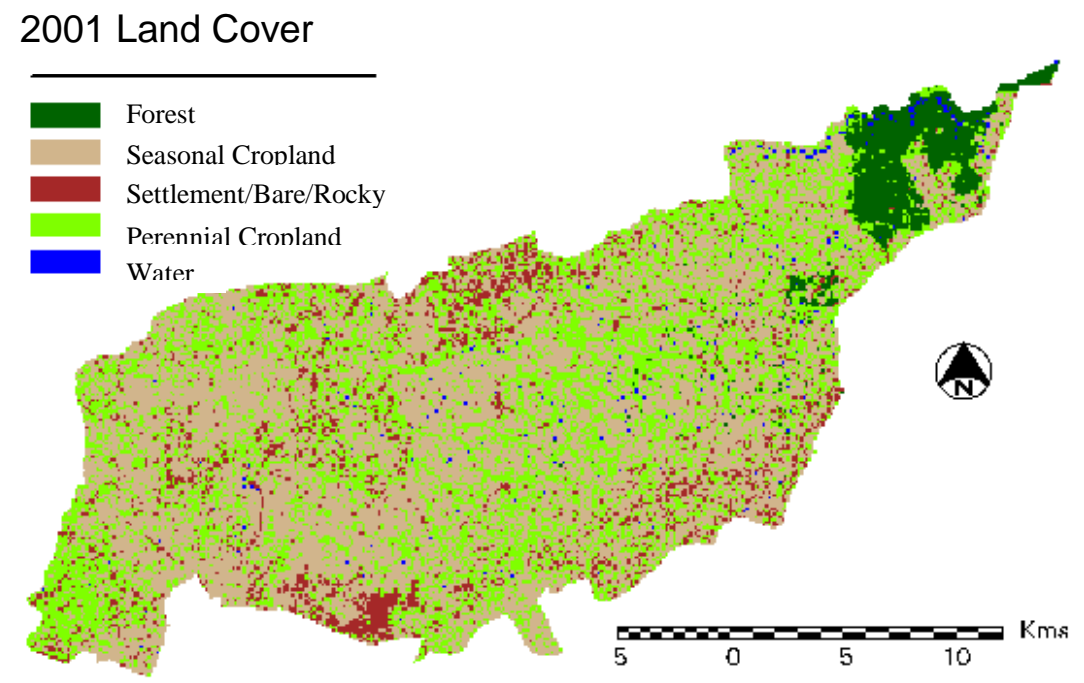

Figure 4.2b: Land cover map for February 5, 2001 


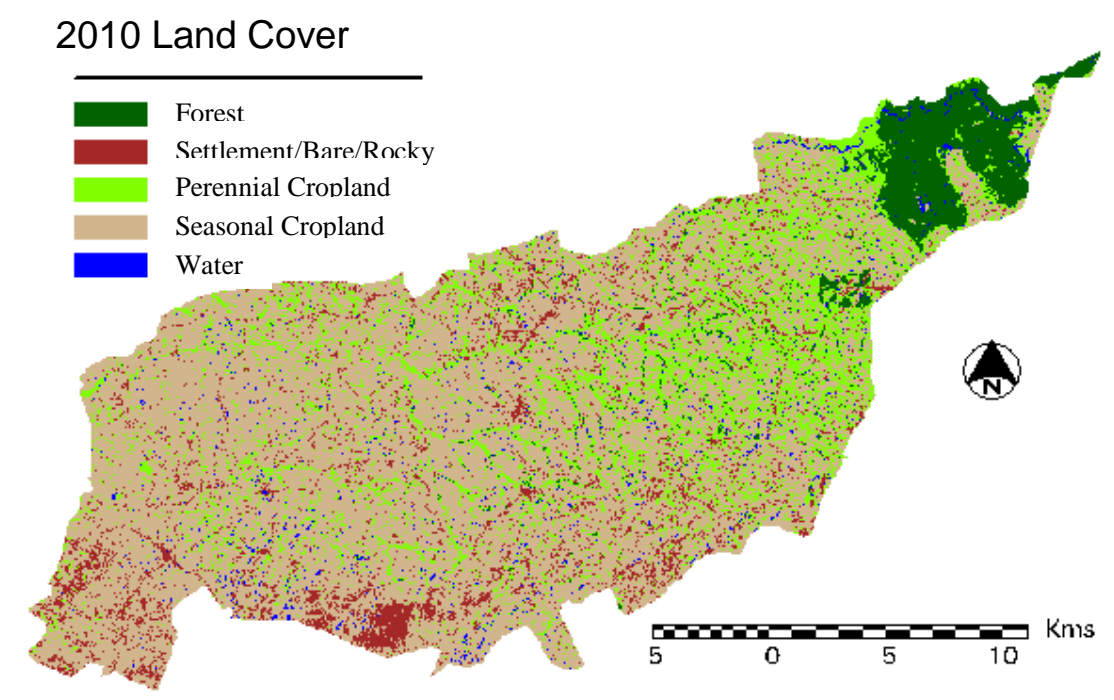

Figure 4.2c: Land Cover Map for December 23, 2010

\subsection{Accuracy Assessment}

One of the major challenges in performing post-classification change detection is the inability to get reference data for accuracy assessment whose date of acquisition is close to the acquisition date of the older images. The decision as to how to proceed is as varied as the number of studies that have been conducted with similar data. In their assessment of the fragmentation and disturbance of west Kenya rain forest, Lung and Schaab (2006) used the original Landsat images, amateur photos and maps. In this study, accuracy assessment was done by loading randomly selected classified pixels on the original Landsat images and visually comparing their location to topographic maps (produced in 1970 by the Directorate of Overseas Surveys and reprinted in 1981 by the Survey of Kenya), aerial photos taken in 1972 and 1978 and my extensive knowledge of the study area. GPS points taken during the fieldwork from December 2010 to March 2011) were only used for the accuracy assessment of the 2010 land use map. For each of the three land cover classes, three hundred pixels were selected using stratified random sampling technique to ensure that all the five classes were included in the selection. Error matrices and Kappa statistics were generated for each of the three land cover maps (Tables 4.1., $4.2 \& 4.3)$. The results showed an overall classification accuracy of $86.7 \%, 88.7 \%$ and $87.7 \%$ for the 1985, 2001 and 2010 maps respectively. 
Table 4.1: Error Matrix for the 1985 Land Cover Map: Overall Accuracy 86.7\%; Kappa 0.752

\begin{tabular}{|c|c|c|c|c|c|c|c|}
\hline \multirow[t]{2}{*}{ Classified Data } & \multirow[b]{2}{*}{ Forest } & \multicolumn{4}{|c|}{ Reference Data } & \multirow{2}{*}{$\begin{array}{l}\text { Row } \\
\text { Total }\end{array}$} & \multirow{2}{*}{$\begin{array}{l}\text { User's } \\
\text { Accuracy (\%) }\end{array}$} \\
\hline & & Agr. I & $\mathrm{S} / \mathrm{B} / \mathrm{R}^{*}$ & Agr. II & Water & & \\
\hline Forest & 22 & 0 & 0 & 4 & 0 & 26 & 84.6 \\
\hline Agriculture I & 0 & 176 & 0 & 13 & 0 & 189 & 93.1 \\
\hline Settlement/Bare/Rocky & 0 & 10 & 15 & 1 & 1 & 26 & 57.7 \\
\hline Agriculture II & 0 & 7 & 0 & 46 & 0 & 53 & 86.8 \\
\hline Water & 0 & 3 & 0 & 2 & 1 & 6 & 16.7 \\
\hline Column Total & 22 & 196 & 15 & 66 & 1 & 300 & \\
\hline Producer’s Accuracy (\%) & 100.0 & 89.8 & 100.0 & 69.7 & 100.0 & & \\
\hline
\end{tabular}

Table 4.2: Error Matrix for the 2001 Land Cover Map: Overall Accuracy 88.7\% ; Kappa 0.801

\begin{tabular}{|c|c|c|c|c|c|c|c|}
\hline \multirow{2}{*}{$\begin{array}{l}\text { Classified } \\
\text { Data }\end{array}$} & \multicolumn{5}{|c|}{ Reference Data } & \multirow[b]{2}{*}{$\begin{array}{l}\text { Row } \\
\text { Total }\end{array}$} & \multirow[b]{2}{*}{$\begin{array}{l}\text { User's } \\
\text { Accuracy (\%) }\end{array}$} \\
\hline & Forest & Agr. I & $\mathrm{S} / \mathrm{B} / \mathrm{R}^{*}$ & Agr. II & Water & & \\
\hline Forest & 14 & 0 & 0 & 0 & 0 & 14 & 100.0 \\
\hline Agriculture I & 0 & 157 & 1 & 6 & 0 & 164 & 95.7 \\
\hline Settlement/Bare/Rocky & 0 & 10 & 16 & 0 & 0 & 26 & 61.5 \\
\hline Agriculture II & 0 & 16 & 0 & 78 & 0 & 94 & 82.9 \\
\hline Water & 0 & 0 & 0 & 1 & 1 & 2 & 50.0 \\
\hline Column Total & 14 & 183 & 17 & 85 & 1 & 300 & \\
\hline Producer's Accuracy(\%) & 100.0 & 85.8 & 94.1 & 91.8 & 100.0 & & \\
\hline
\end{tabular}

* S/B/R = Settlement, Bare and/or Rocky

Table 4.3: Error Matrix for the 2010 Land Cover Map: Overall Accuracy 87.7\%; Kappa 0.772

\begin{tabular}{|c|c|c|c|c|c|c|c|}
\hline \multirow{2}{*}{$\begin{array}{l}\text { Classified } \\
\text { Data }\end{array}$} & \multicolumn{7}{|c|}{ Reference Data } \\
\hline & Forest & $\mathrm{S} / \mathrm{B} / \mathrm{R}^{*}$ & Agr. II & Agr. I & Water & $\begin{array}{l}\text { Row } \\
\text { Total }\end{array}$ & $\begin{array}{l}\text { User's } \\
\text { Accuracy (\%) }\end{array}$ \\
\hline Forest & 17 & 0 & 3 & 0 & 0 & 20 & 85.0 \\
\hline Settlement/Bare/Rocky & 0 & 17 & 1 & 5 & 0 & 23 & 73.9 \\
\hline Agriculture II & 0 & 0 & 53 & 4 & 0 & 57 & 92.9 \\
\hline Agriculture I & 0 & 1 & 23 & 173 & 0 & 197 & 87.8 \\
\hline Water & 0 & 0 & 0 & 0 & 3 & 3 & 100.0 \\
\hline Totals & 17 & 18 & 80 & 182 & 3 & 300 & \\
\hline Producer's Accuracy(\%) & 100.0 & 94.4 & 66.3 & 95.1 & 100 & & \\
\hline
\end{tabular}




\section{Results}

\subsection{Forest loss on the Maragoli Hills}

The results of the post classification comparison show significant fluctuations in the areal extent of the five land cover classes with the seasonal cropland (Agricultural I) constituting most of the county's land cover at $68.8 \%$ in $1985,58.7 \%$ in 2001 and $71.7 \%$ in 2010 (Table 4. 4). The second largest areal extent is the perennial crops and trees (Agriculture II) which covered 17.9\% in $1985,33.9 \%$ in 2001 and $18.9 \%$ in 2010 . The maps also show a $2.9 \%$ decline in forest cover from 4275 hectares in 1985 to 2723 hectares in 2001 but then went up by $1.6 \%$ to 3567 hectares by 2010. During the 1985 to 2001 period, 14.2\% (607 ha) forest cover was converted to farms, $6.17 \%$ (263 ha) into bare/rocky areas and 28.7\% (1226 ha) converted to perennial crops and tree cover. Much of the conversion to bare/rocky class is evident to the south of the County, around the Maragoli Hills (in the present day Vihiga district) where the forest was harvested, exposing the rocky landscape (Fig. 4.2a).

Table 4.4: Areal extent of the different land cover classes 1985, $2001 \& 2010$ (in hectares)

\begin{tabular}{lllll}
\hline Land Cover Class & 1985 (ha) & 2001 (ha) & 2010 (ha) \\
\hline Forest & 4275 & $(8 \%)$ & $2723(5.1 \%)$ & $3567(6.7 \%)$ \\
Agriculture I & 36563 & $(68.8 \%)$ & $31193(58.7 \%)$ & $38071(71.7 \%)$ \\
Settlement/Bare/Rocky & 4936 & $(9.2 \%)$ & $4868(9.1 \%)$ & $4517(8.5 \%)$ \\
Agriculture II & 9542 & $(17.9 \%)$ & $18011(33.9 \%)$ & $10043(18.9 \%)$ \\
Water & 1758 & $(3.3 \%)$ & $361(0.6 \%)$ & $878(1.6)$ \\
\hline
\end{tabular}




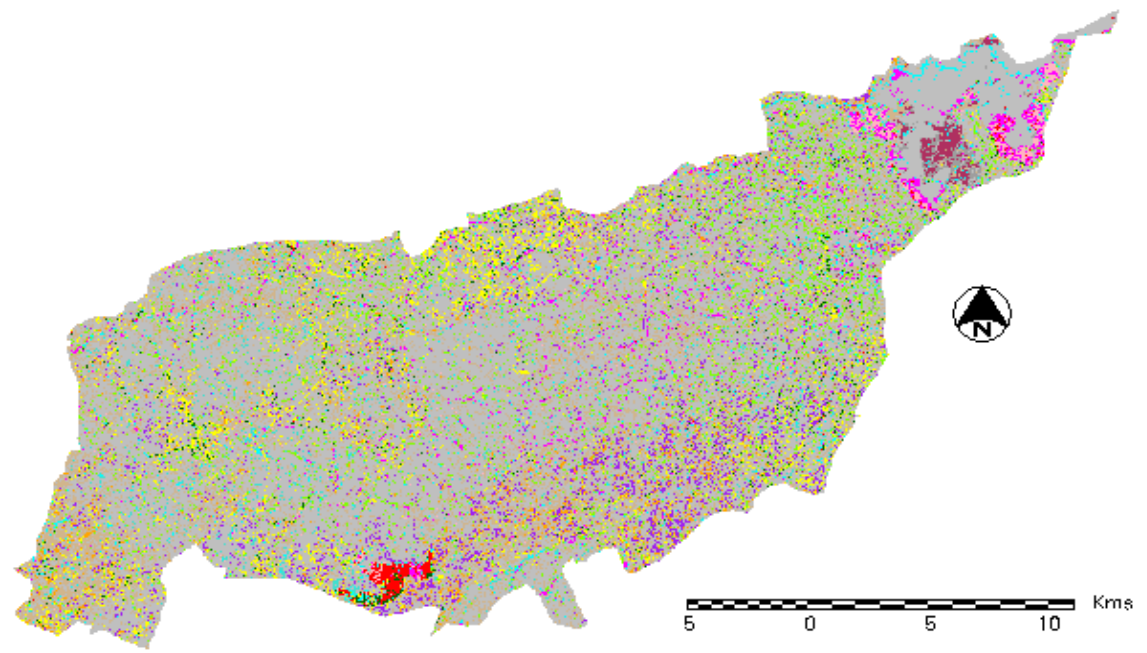

Figure 4.3a: Land cover Change Map 1985 - 2001

\section{Legend}

Forest to Farms

Forest to Trees/Permanent Crops Farms to Settlement/Bare/Rocky Settlement/Bare/Rocky to Farms Trees/Permanent Crops to Forest Trees/Permanent Crops to SBR No Change

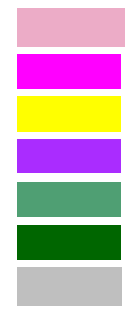

Forest to Settlement/Bare/Rocky Farms to Forest Farms to Trees/Permanent Crops Settlement/Bare/Rocky to Trees Trees/Permanent Crops to Farms Other Changes

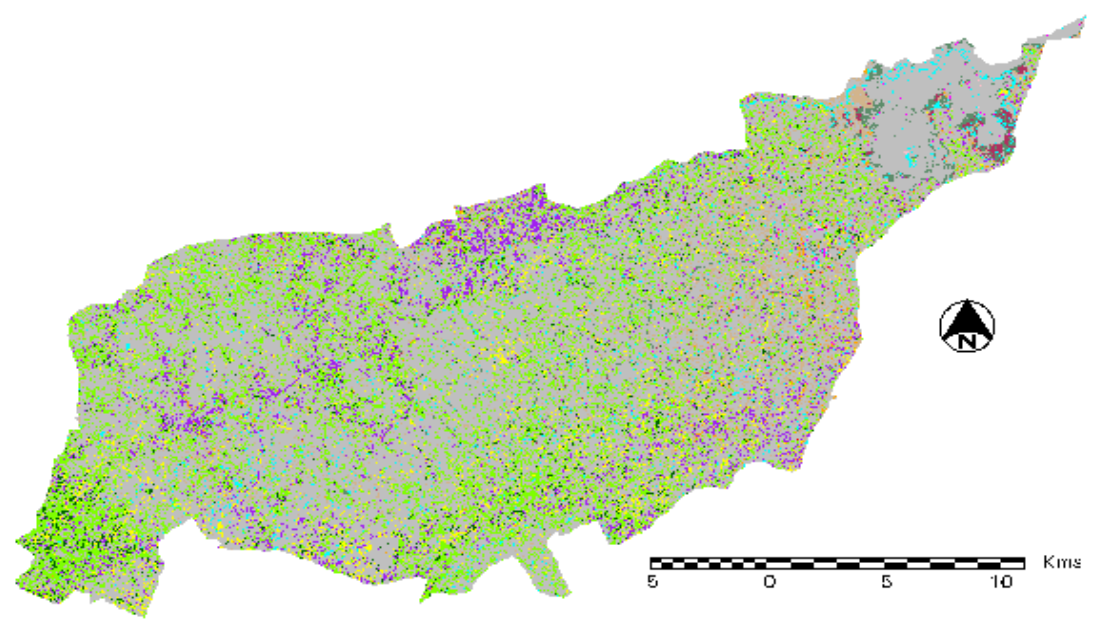

Figure 4.3b: Land Cover Change Map 2001 - 2010 
The deforestation and subsequent afforestation efforts on the Maragoli hills is an issue that has generated significant interest and debate within the local communities, government agencies and NGOs. At the center of these debates is the issue of ownership of the land on which the forest was planted with the families residing on the hilltop claiming that the land was forcefully alienated by the colonial government to plant the forest while the government through the forest department claims that this is gazetted forest land. The contestation over this space has often degenerated into confrontations between area residents and government representatives including incidents where area residents defy government directives on cutting down trees and sabotage reforestation efforts by uprooting tree seedlings. These acts of defiance go as far back as the early 1950s when the initial attempts were made by the colonial forest and agricultural officers to plant trees on the hills as part of the soil conservation efforts under the Swynnerton Plan. Archival documents from 1955 indicate the kind of tension that existed during this time:

The afforestation of the Maragoli and Bunyore hills financed by the Swynnerton funds primarily as soil conservation measure has proved a bone of contention in the locations concerned throughout the year but the opposition which was at one time exceedingly strong has been worn down. It is inevitable that in such an overcrowded area the people should oppose what they regard as the loss of further land however useless it may be to them. They appear now to be persuaded that the land will not in fact be stolen from them by the government and that the scheme will be of real local benefit. (North Nyanza Annual Report 1955, p. 12 - 13)

Clearly, area residents were wary of the intentions of the colonial government but were subdued and allowed the forest to be planted. The government on the other hand misread the lack of trees in the area to imply deforestation due to overpopulation yet older residents of the area point out that because of its rocky terrain, the only vegetation on the hills prior to this intervention was shrubs and tall grasses and not trees. This misinterpretation of the landscape reflects what Fairhead and Leach (1996) refer to as 'misreading of the landscape' and which often leads to misguided intervention strategies. Such strategies that are driven by neo- Malthusian thinking were not unique to Vihiga during this period. Nonetheless, the government succeeded in planting exotic trees on the hill, which after several decades became the Maragoli forest, complete with wild animals such as leopards and monkeys. Area residents living on the hill recount with bitterness their various unpleasant encounters with these wild animals, who many contend were not native to the area but were released into the forest by the colonial forest officers to intimidate 
the area residents and force them to leave the hills. One of the older respondents who has lived on the hill from 1945 before the trees were planted recounted these experiences:

The biggest problem we had was with the leopards. Before the trees were planted here we never had such problems... but after the trees were planted, our goats were eaten, our cows were eaten and they even ate a young girl called Jahenda, who was my neighbor. Another young man was mauled so badly and had to be rushed to Kakamega hospital. We had to make sure that all the livestock were secured indoors by $4.00 \mathrm{pm}$. But those leopards had not always been here. They were brought by the wazungus after planting the trees. We know because all the leopards that the people killed had a number stamped on the neck. Some people chose to sell their land and move to Kanyamkago (South Nyanza). But now that the trees are not there, we have some relief and our lives are so much better. (Salome Lugasi (age unknown), moved to the hill in 1945 to get married - Interview on March 3, 2011)

Such sentiments are echoed by most of the hill residents who also claim that apart from the threats posed by the leopards, the monkeys that also inhabited the forested areas were equally destructive. They often destroyed the food crops on the farms, forcing households to designate family members (often the children) to keep watch around the clock. The immediate consequence of such actions was that many of the children could not attend school and so the illiteracy levels on the hill are relatively higher than in most other parts of the County.

During the 1990s, a second confrontation ensued between the government and inhabitants of Maragoli hills. This time the bone of contention was the deforestation of the hills. According to local residents, government officials began harvesting the trees without involving them (residents) and in response, the area residents embarked on indiscriminate cutting of the trees to make timber and charcoal. Attempts by government officials to stop the harvesting of the forest were met with defiance and by 1997 the whole forest has been cleared, leaving a bare rocky landscape. In recent years, various government agencies and nongovernmental organizations have attempted reforestation of the hills with minimal success. Even when some of the residents appear to agree to the reforestation proposals, the seedlings that are planted are often uprooted at night by those against this move, just like the 1950s when trees were first planted on the hill. For many of the families still residing on the hill, the clearance of the forest in the early 1990s was in fact a blessing to them as they now do not have to resort to such desperate measures to protect their crops and livestock. Consequently, they are apprehensive of any efforts to regrow the forest as expressed by one of the local administrators: 
The people on this hill argue that if the forest is planted again, the wild animals that used to harass them will come back and they will have the same problems that they had. Some say that people used to come and commit suicide here, criminals used to come and hide here, some of their wives use to be raped, some people just used to disappear without a trace and they cannot tell if wild animals ate them or not, and they had to watch their crops around the clock so that monkeys could not destroy them. Their thinking now therefore is that if the hill is rehabilitated, then they will be faced with the same problems that they had earlier. (Esther Vidija, Assistant Chief - Mahanga Sub-location, Interview March 2, 2011)

There is a lack of consensus among area residents on the effect of the loss of forest cover to the micro climate and rainfall regime of the area. Residents who live at the foot of the hill argue that the clearing of the forest has negatively affected the rainfall with the onset of the rains becoming more erratic and with declining intensity. They argue that this has resulted in a decline in the net crop yield, sending families to the market to buy food earlier than they normally would. Most of them support efforts to plant trees and regrow the forest while the residents at the top prefer that individual households engage in some form of farm forestry rather than replanting the forest. The link between forest loss and erratic and declining rainfall is also disputed by the residents on the hill who argue that there is no connection between the presence of the forest and the rainfall regime in the area.

When the trees were here we used to get good rainfall. But even before the trees were planted, the rains were still good. The rainfall pattern has changed, but it is not because of the trees. (Salome Lugasi, Maragoli Hills resident since 1945, Interview March 3, 2011)

This situation is further compounded by claims made by the residents on the hill that the land on which the forest was originally planted was not government land but belonged to their parents and grandparents. Instead they are demanding that the government issues them with title deeds to prove their ownership. 


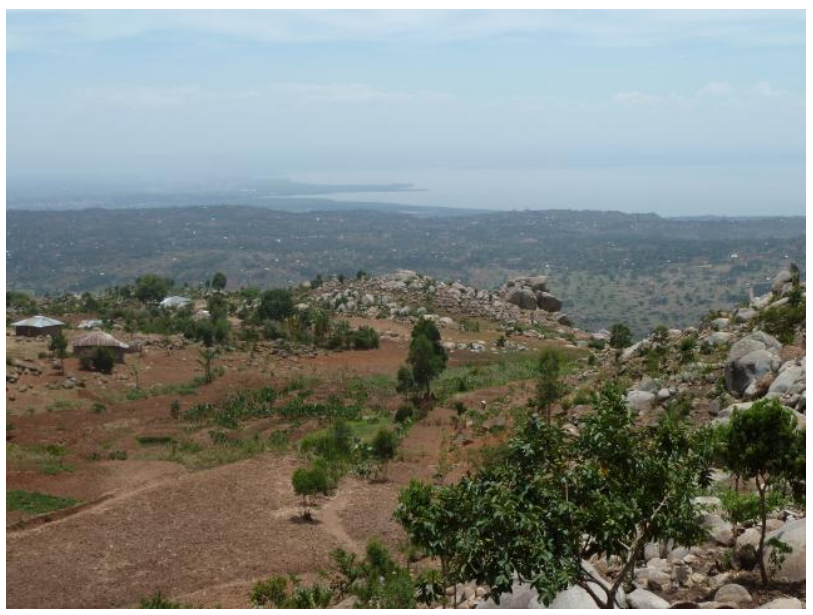

Figure 4.4: Farms and homes on the Maragoli Hills in the foreground overlooking Lake Victoria in the background

(Source: Author, March 2011)

\subsection{Forest Regeneration}

While the Maragoli forest was completely cleared in the the 1990s, the Kibiri forest in the north eastern part of the county appears to have undergone significant regeneration during this same period. This trend continued into the next phase and between 2001 and 2010, the areal extent of forest class went up by $13 \%$ which included the conversion of some of the perennial crops/shrubs land cover class into forest. This increase in the forest class coincided with a government ban on the use of forest resources by communities living around the forest and the introduction of a user fee for any products obtained from the forest. The Kenya Forest Act (2005) gives the forest officers the powers to arrest any individuals found with forest products without a license:

A Forest officer may demand from any person the production of an authority or license for any act done or committed by that person in a state, local authority or provisional forest in relation to any forest produce for which a license is required under the Act or under any rules made thereunder. (Section 501 (a), Kenya Forest Act 2005, p. 279)

During the period under study, the Forest Department also embarked on aggressive planting of exotic species of trees such as cypress and pine trees for commercial purposes. The first growth forest cover in the larger Kakamega forest was known for its indigenous tree species such as Elgon teak, red stinkwood, and African satinwood. According to the Forest Officer in 
charge, these species of trees "attract" rains more than the exotic species (Forest Officer-incharge, Kibiri Forest Station, personal communication, March 2011). The result of this action of planting non-indigenous trees for commercial purposes is a regeneration of forest cover that appears on the 2001 and 2010 images. The implication of this approach to forest management that entails the enclosure of the forest is that communities around the Kibiri forest who relied on cultivating in the forest to supplement the harvest from their small farms began to rely more on the local market to make up the deficits in food production. With the commodification of the forest products, access to the forest is now limited to those who can afford to purchase the permits for the different forest products.

At face value, it appears that neoliberal policies in this case have succeeded in curbing deforestation by allowing trees to grow in areas that were partially deforested and had been turned into farms. But this appearance masks the fact the all the second growth forest cover consists mainly of alien species that are not native to the area and are grown for commercial purposes. Once they are mature (which may be in 8 to 15 years depending on the species), they are harvested and sold to logging companies to generate revenue for the Forest Department. This exemplifies the underlying justification of neoliberal economic policies for natural resource management in the global South.

\subsection{Changes in agricultural land use}

The 1985 - 2001 land cover change map shows some conversions of forest cover, bare/rocky, and perennial crops/trees classes into seasonal cropland. While the conversion of forest cover was confined to the forest areas, the conversion of the bare/rocky class and the trees class was spread out across the county and is indicative of extensification efforts as households were pushed to previously uncultivated areas in the rocky terrain to the south of the County due to dwindling farm sizes.

However, seasonal cropland was also converted into other land cover/uses during this period with $26.5 \%$ being converted into perennial crops/trees. This is indicative of an expansion in farm forestry to cater for the persistent need for wood in the area for fuelwood and construction and also the increased adoption of tea as a cash crop due to the construction of a tea factory in the 
County in the mid-1990s. This trend is reflected in the declining maize production as tea production increases (see Fig. 4.5). Idalinya \& Liebig (2008) noted that between 2002 and 2006, maize production declined from 37280 tons to 28930 tons while tea production went up from 9050 tons to 11866 tons.

During the 2001-2010 period, $6 \%$ of the seasonal cropland was converted into settlement/rocky/bare class and $12.1 \%$ converted into perennial cropland. The former includes the road improvement projects that intensified since 2003 through government projects like the Constituency Development Fund. These projects involve paving, and widening existing roads to make them all weather and are part of the government efforts to improve access to rural areas.

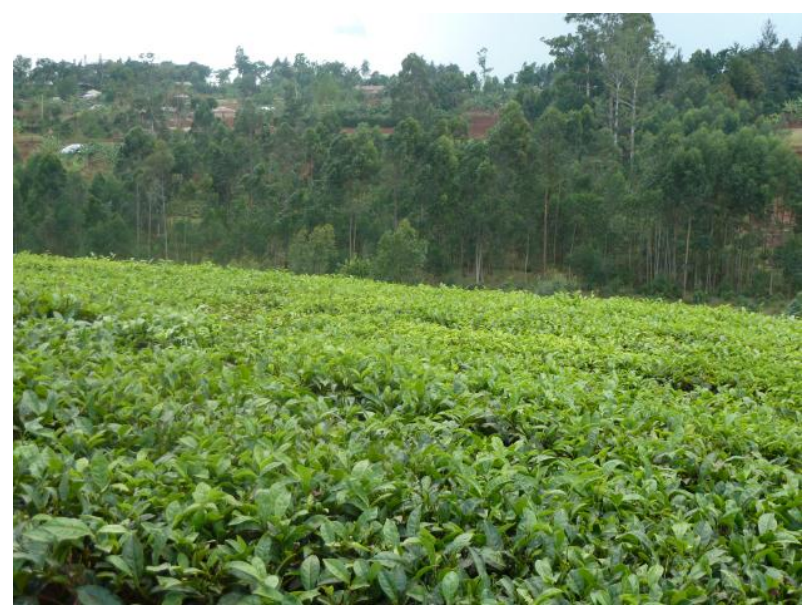

Figure 4.5: Cultivation of tea and eucalytpus trees

(Source: Author, March 2011)

Closely related to the improvement of infrastructure is the expansion of market centers into peri-urban areas that are attracting finance capital while also connecting rural areas to the global world via the internet provided by mushrooming cyber cafes. This trend is not apparent in the Landsat imagery because it is occurring at a much finer spatial scale and much of the ongoing expansion is more vertical in the form of multi-storeyed buildings to maximize on the limited land as shown in Fig 4.7. However, a comparison of aerial photos for the area obtained in 1978 with current Google earth images shows some horizontal expansion (Fig. 4.6). Peri-urban expansion is an important dimension of rural change in this area as households engage more in market based 
livelihoods strategies. Most young people come to these centers daily in search for some form of casual jobs that include transportation (using motorbike or bicycle taxis), hawking merchandise, working as porters and other similar jobs. Located strategically along the major roads, market centers such as Mbale, Majengo, Shamakhokho, Chavakali and Luanda provide services such as internet, accommodation, banking, schools, supermarkets, recreation and housing which link rural communities to the global world.
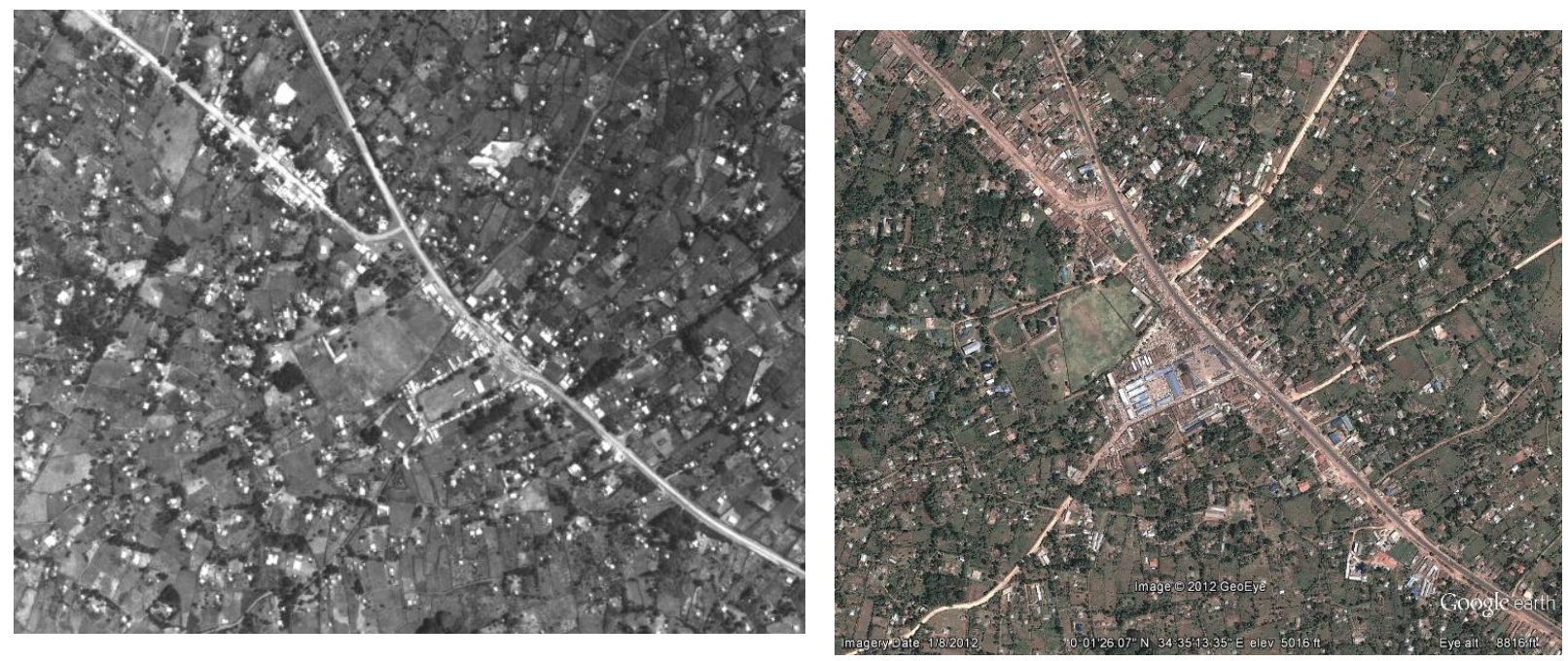

a.)Luanda
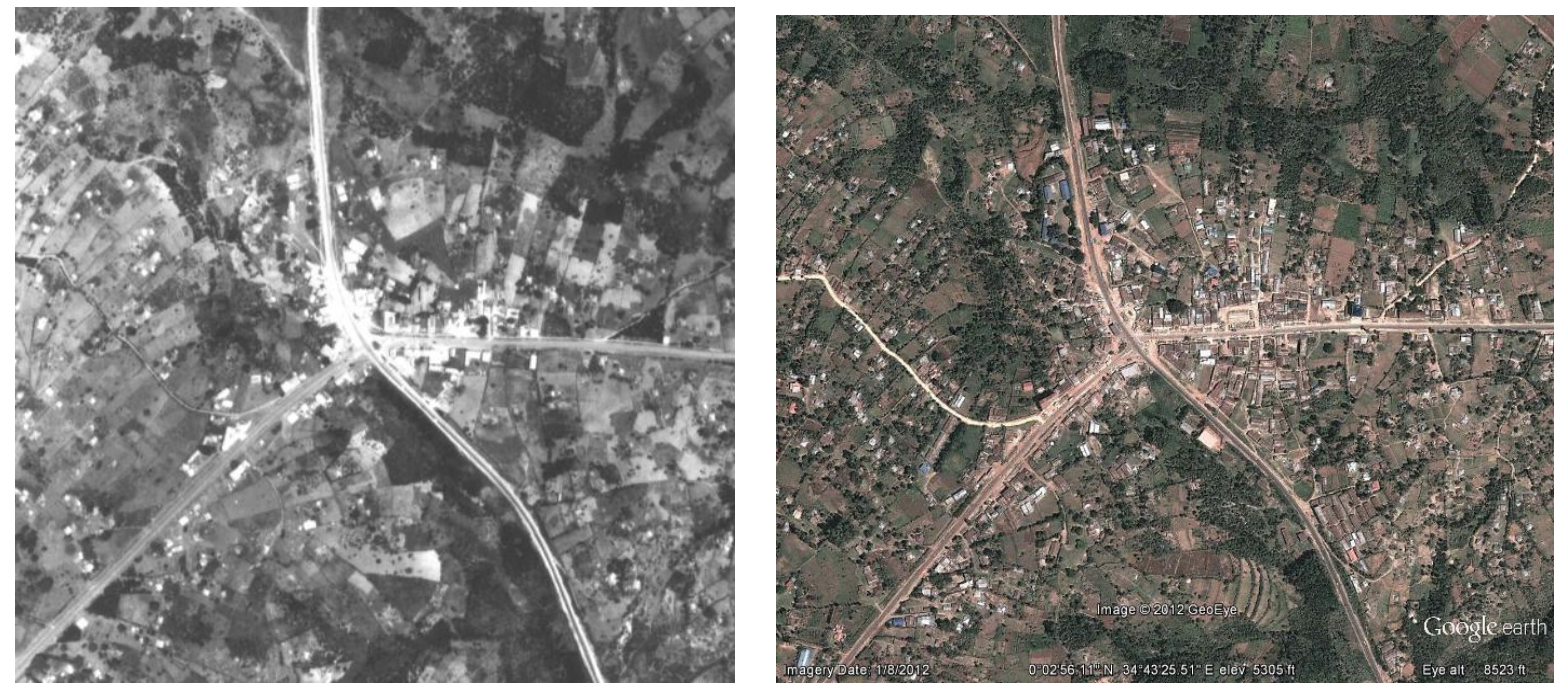

b.) Majengo 

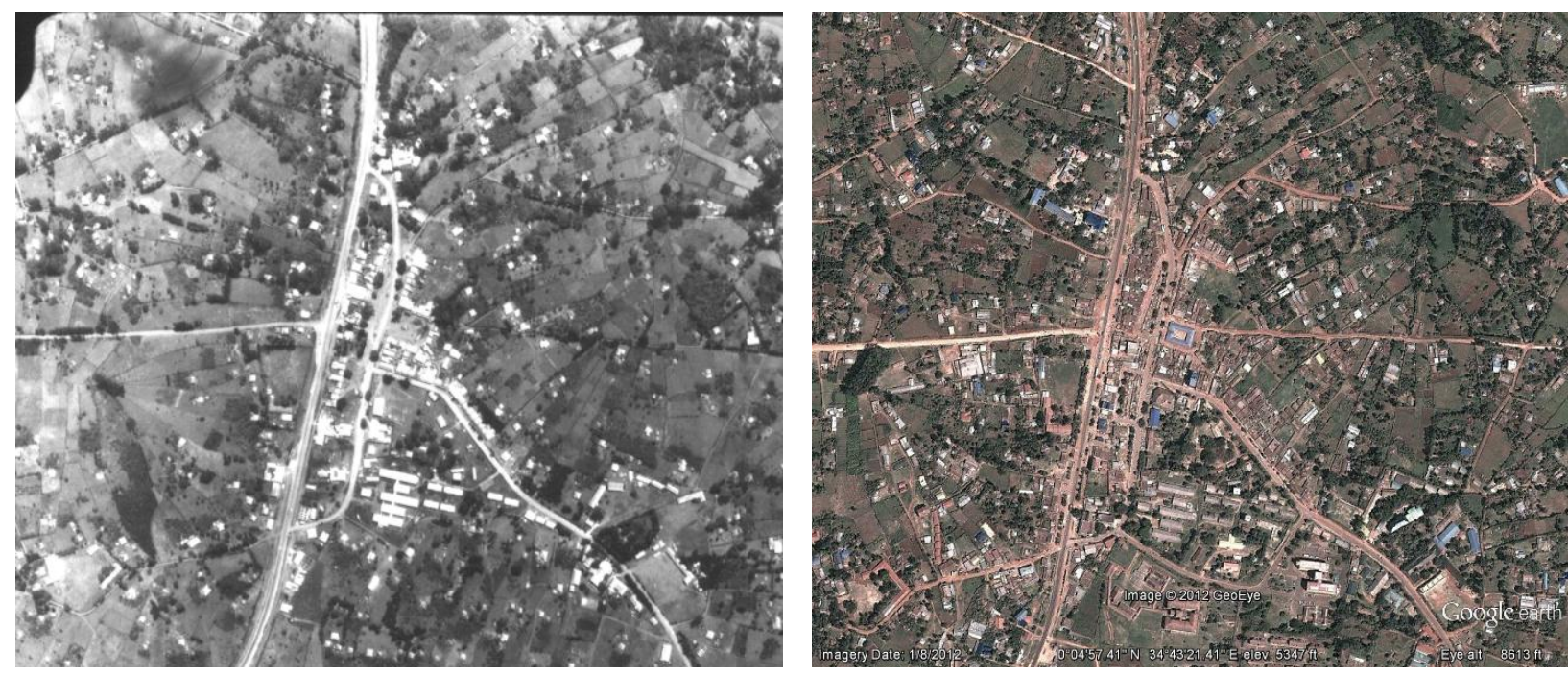

c.) Mbale

Figure 4.6: Peri-urban expansion of market centers as shown in 1978 aerial photos (on left) and 2012 Google Earth images (on right)

(Source: Survey of Kenya \& Google Earth 2012)
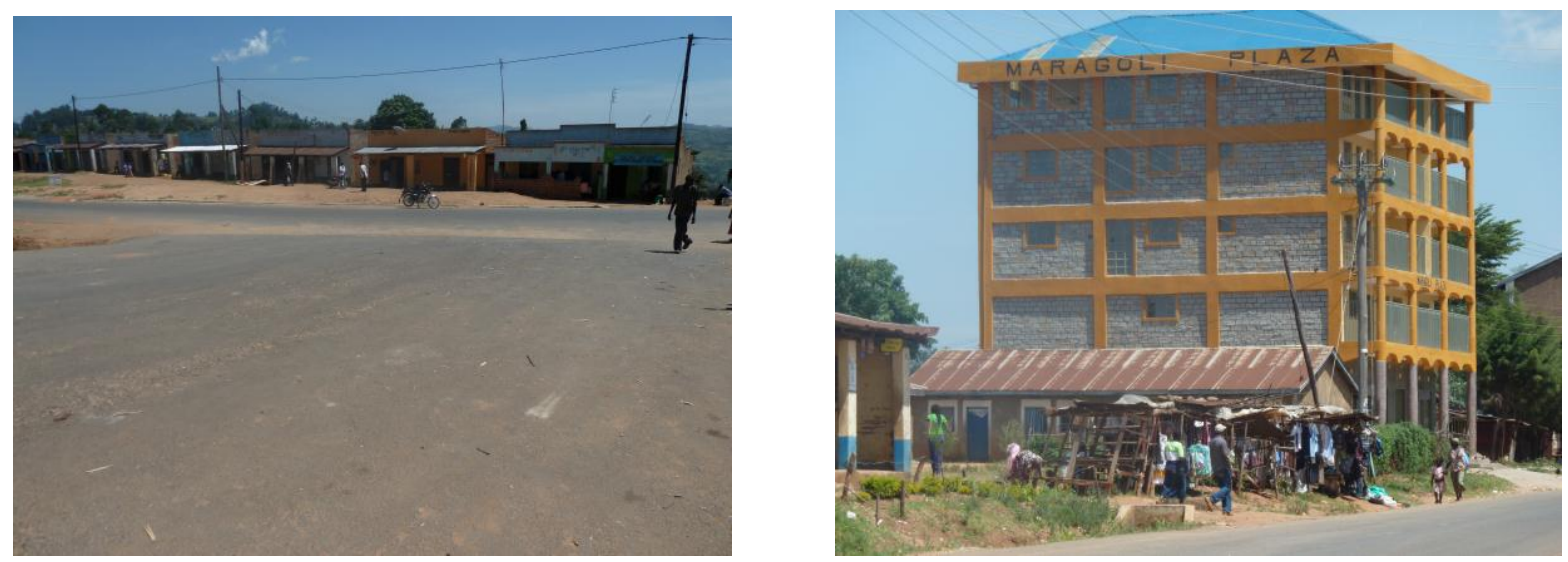

Figure 4.7: Vertical Expansion of market centers as shown in new developments on the right compared to older buildings on left

Source: Author (March 2011) 


\section{Capital penetration, commodification of nature and the production of rural space}

The findings of this study shed light on the varied spatio-temporal forms of stabilizations that reflect a landscape that is undergoing rapid transformation. Two of the main underlying processes in this change are the enhanced circulation of capital and commodification of nature. Smith 2008 notes that "when this immediate appearance of nature is placed in historical context, the development of material landscape presents itself as a process of production of nature (p. 50). While change by itself is inevitable, the nature of physical changes occurring here are reflexive of the ongoing changing social relations within a capitalist economy where production of exchange values has taken preeminence over production of use values. The appearances of the produced nature and space however are precluded by historical moments, with the first such moment occurring during the colonial period when Vihiga, like many other parts of rural Africa became connected to the global capitalist economy (albeit in a lopsided way). The second moment (which is the focus of this paper) is associated with the adoption of neoliberal economic policies that, while building on the first moment, appears to accelerate the transformations that began with the first moment.

The tangible signs of the process of enhanced capital circulation are evident in the expansion of market centers into peri-urban centers. A casual comparison of the aerial photos taken in the 1970s and the 2012 Google Earth images does not adequately reflect the nature of transformations that are taking place and this is because of two reasons. First, the lack of physical space for expansion has meant that the areal extent for most of these market centers has barely changed. As a result, most of the physical expansion is occurring in a vertical rather than horizontal way and hence the numerous multi-storeyed buildings that are quickly becoming the trend. Second and most significant in this study is the fact that these centers now provide services that enhance the process of capital circulation which range from banking services, cell phone money transfer kiosks, supermarkets and internet services. Their role has been transformed from being centers of simple exchange of commodities to centers of enhancing the connection of this area to the global economy. The kind of expansion that is occurring is more relative than absolute. Smith notes that this process is a classic progression in capitalist development where process of production of exchange values and the accompanying social relations is evident in the 
expansion of market centers into urban areas that provide "ancillary services" that "contribute to their development" (Smith 2008, p. 60).

Similarly, improved communication and transportation networks enhance the circulation of different forms of capital that include commodity capital, merchant capital, finance capital and labor in a process that Marx refers to as the "annihilation of space by time"; a form of time-space compression. The improved road network is making it easier to access areas that were previously inaccessible, making it possible to circulate commodities from around the world into the interior parts of the County. Harvey (2003) notes that the need to reduce the "time and cost of movement has proven a compelling necessity of capitalist mode of production" (p. 98) due to pressure to "accelerate turn over time" (Harvey 1996, p. 411). Such compulsion is what drives the investments in communication and transportation infrastructure, schools and healthcare facilities that enable the reorganization of rural space hence producing new geographical landscapes. The improved accessibility is already being reflected in the variety of imported consumer goods that are sold in most of the village shops are made in China and India. This has been made possible by the free market neoliberal economic policies that have 'killed' local manufacturing initiatives. Many residents acknowledge the benefits of having good roads, such as the ability for their tea to be collected on time and how fast it is nowadays to access merchandise to sell in the village shops. Consumer commodities that could only be found in larger stores in urban areas are now easily available in the village shops. Similarly, the transfer of money by cell phone technology is making it possible to move large sums of money into the remotest parts of the County within a few minutes. Such innovations in communication and information technology contribute to the rate of circulation of capital and to the process of uneven geographical development.

As access to remote areas improves, market centers are quickly attracting both capital and labor. This is evident in the increase in financial institutions, private schools, supermarkets, gas stations and other types of businesses. These centers are now frontiers for the accumulation of capital and the local youth who flock these centers from the nearby villages come expecting to benefit somewhat from this process. While some of the youth may be lucky to land some casual jobs as transporters, porters or cleaners, many are not as lucky and end up in situations that are worse off than they anticipated. This reflects Harvey's (1996) observation that rural dwellers who flood urban centers seek to "take advantage of capitalist produced possibilities no matter 
whether capital accumulation is going on or not, and often in the face of economic conditions that are just as, if not more appalling than those left behind" (p. 415).

The second major underlying change process is the commodification of nature which is evident in the changes in forest cover both on the Maragoli Hills and at the Kibiri forest as well as the changes in land use at the household level. Castree (2003) identifies five distinguishing characteristics of commodification that include privatization, alienability, individuation, abstraction, valuation and displacement. Most instances of commodification of nature are likely to exhibit several of these characteristics. The case of the growth and subsequent loss of forest cover on the Maragoli hills cannot be fully understood outside the historical context of how the forest came to be in existence in the first place. The actions of the colonial government at the time of planting trees on the hills in the 1950s is reminiscent of the process of accumulation by dispossession where local residents were violently dispossessed of their rights to use the land and had underpinnings of a kind of privatization where the state gave itself the full ownership and rights to the land.

Privatization, Castree (2003) notes, is a "precondition for capitalist accumulation". Under the guise of soil conservation efforts, the state proceeded to enclose the hills and plant trees, an act that characterizes the alienability and individuation characteristics of commodification. This scenario reinforces Akram Lodhi's analysis of the commodification process as being "intimately entwined with enclosure" (Akram-Lodhi 2007 p.1444). The type of the trees that were planted included cypress and pine trees which are not indigenous to the area and mature relatively faster than indigenous types of trees. This strategic move was to ensure that the trees would be ready for harvesting after a short period of time. However, this plan was interrupted, albeit briefly, when Kenya became independent in 1963 but in the early 1990s, government forest officers began harvesting the trees to sell to timber factories. Some of the local residents, in reaction to this also began cutting down the trees to make charcoal for sale. This process was predicated on the individuation characteristic of commodification, which "involves putting legal and material boundaries around phenomenon so that they can be bought, sold and used by equally bounded individuals, groups or institutions" (Castree 2003, p. 280) 
Current efforts to reforest the Maragoli hills have been met with some resistance from a section of the local community. The typical approach that is used by many of the governmental and non-governmental agencies is predicated on "environment first" thesis that presupposes the duality of nature and society. The fact that little success has been realized in spite of the numerous efforts that have been made indicates that there is need to rethink this approach and its theoretical basis and perhaps acknowledge the unity of nature and society.

The loss and subsequent regeneration of forest cover in the Kibiri forest further reinforces the role of the state in the process of commodifying nature. The adoption of neoliberal policies in the 1990s called for the enclosure of forest resources hence denying communities living adjacent to the forest access to these resources. Prior to the adoption of these policies, households around Kibiri forest were permitted to cultivate portions of the forest while tending the trees. This changed after neoliberal policies were adopted as the Forest department opted to plant fast maturing tree species such pine and cypress for commercial purposes. Subsequently, imagery that reflects a regrowth/regeneration of the forest area as reflected in the Feb 52001 Landsat image used in this study can be used to justify the enclosure policies while in reality, this regrowth is harvested for logging to generate income for the forest department and private companies.

At the household level, the process of commodification is occurring in a slightly different way. Agricultural productivity has evolved over the years from producing use values (subsistence production) to a kind of "bifurcated structure" (Akram Lodhi 2007) where production for the market coexists alongside producing for subsistence. Whether it is producing tea that eventually is sold on the global market or producing bananas or trees that are sold to individuals, production for the market can be viewed as a commodification of rural labor and products. However, because of the connection to the global economy, tea growing is an example of the "remote controlled" exploitation of poor rural farmers who are, for the most part, not making any profit. The fact that they have to wait for a year before they get the full payment for the tea delivered further exacerbates this exploitative process. Having committed a sizable portion of their land to tea growing, these farmers have less land to plant food crops and are now at the mercy of global tea markets that are controlled by multinational corporations that operate like cartels. 


\section{Conclusion}

This paper has examined the political economy of land use and cover change with the aim of highlighting how rural spaces are being reworked and produced in the wake of the accelerated penetration of capital that characterizes neoliberal economic change. The use of Landsat imagery, aerial photos and Google images captures the still moments of a changing rural landscape in Vihiga, western Kenya, over a 25 - 30 year period but it is the processes and relations that constitute and sustain this change. While acknowledging that there are numerous processes and relations involved in this change process, this analysis identifies two of these that can be attributed to the neoliberal economic change to be enhanced circulation of capital and commodification of nature.

\section{References}

Akram-Lodhi Q. 2007. Land Markets and neoliberal enclosure: an agrarian political economy perspective, Third World Quarterly 28 (8): 1437 - 1456

Aritho L. 1995. The Effect of Household Income and Seasonal Price Changes on Household Food Expenditure Patterns: A case study of Vihiga, Report No. 57/1995, Food and Nutrition Studies Program, Egerton University, Kenya

Awange, J. L., Ogalo, L., Bae, K. H., Were, P., Omondi, P., Omute, P., \& Omullo, M. 2008. Falling Lake Victoria water levels: Is climate a contributing factor?. Climatic Change, 89(3), 281297.

Berry Sara 1993. No Condition is Permanent: the Social Dynamics of Agrarian Change in sub Saharan Africa. University of Wisconsin Press, Madison

Boakye E., Odai S. N., Adjei K. \& Annor F. O. 2008. Landsat Images for Assessment of Land Use and Land Cover Changes on the Barekese Catchment in Ghana, European Journal of Scientific Research 21 (4): 617 - 626

Brink A. \& Eva H. 2009. Monitoring 25 years of land cover change dynamics in Africa: A sample based on remote sensing approach. Applied Geography 29: $501-512$ 
Brink A. \& Eva H. 2011. The potential use of high resolution Landsat satellite data for detecting land cover change in the Greater horn of Africa, International Journal of Remote Sensing 32 (21): $5981-5995$

Bryceson D. Kay C. \& Mooij J. (eds.) 2000. Disappearing Peasantries? Rural Labor in Africa, Asia and Latin America. Intermediate Technology Publications, London

Campbell D., Lusch D., Smucker T \& Wangui E. 2005. Multiple Methods in the study of driving forces of land use and land cover change: A Case of SE Kajiado District, Kenya, Human Ecology: An Interdisciplinary Journal 33 (6): 763 - 794

Castree N. 2003. Commodifying what nature? Progress in Human Geography 27 (3): 273 - 297

Cihlar J. 2000. Land Cover Mapping of large areas from satellites: status and research priorities. International Journal of Remote Sensing 21 (6): 1093 - 1114

Coppin, P.I; Jonckheere, K. \& Nackers, B.M. 2004. Digital change detection in ecosystem monitoring: a review. International Journal of Remote Sensing, 25, (9): 1565-1596.

Crews K. \& Walsh S. 2009. Remote Sensing and the Social Sciences. In: T.A. Warner, M.D. Nellis and G.M. Foody, SAGE Handbook of remote sensing. SAGE, London, UK. Chapter 33: $437-445$.

Conelly W. \& Chaiken M. 2000. Intensive Farming, Agrodiversity and Food Security under conditions of extreme population Pressure in Western Kenya. Human Ecology 28 (1): 19 - 51

Crowley E. \& Carter S. 2000. Agrarian Change and the Changing relationships between Toil and Soil in Maragoli, Western Kenya (1900 - 1994). Human Ecology 28 (3): 383 - 414

DeFries, R., Asner, G. P., \& Foley, J. 2006. A glimpse out the window: landscapes, livelihoods, and the environment. Environment: Science and Policy for Sustainable Development, 48(8), 22 36.

Dewan A. \& Yamaguchi Y. 2009. Land Use and Land Cover Change in Greater Dhaka, Bangladesh: Using remote sensing to promote sustainable urbanization. Applied Geography 29 (3): $390-401$

Ellis F. 2000. Rural Livelihoods and Diversity in Developing Countries. Oxford University Press 
Fairhead J. \& Leach M. 1996. Misreading the African Landscape: Society and ecology in a forest - savanna mosaic. Cambridge University Press. Cambridge, NY

Forkuor G \& Cofie O. 2011. Dynamics of Land Use and Land Cover Change in Freetown, Sierra Leone and its effects on urban and peri-urban agriculture - a remote sensing approach, International Journal of Remote Sensing 32 (4): 1017 - 1037

Harvey D. 1996. Justice, Nature and the Geography of Difference. Oxford, Blackwell

Harvey D. 2001. Spaces of Capital: towards a Critical Geography. Routledge. NY

Idalinya J. \& Liebig J. 2008. Interlinks between cash crops, food crops, food security and smallholder farming in Western Kenya: Disentangling the old rural development fashion? Conference on the International Research on Food Security, Natural Resource Management and Rural Development, University of Hohenheim Oct. 7 - 8, Tropentag

Jansen L., Bagnoli M. \& Focaccci M. 2008. Analysis of land cover/use change dynamics in Manica Province in Mozambique in a period of transition 1990 - 2004. Forest Ecology and Management 254: 308 - 326

Jensen J., Garcia-Quijano M., Hadley B., Im J. \& Wang Z., Nel A., Teixeira E., \& Davis B. 2006. Remote Sensing Agricultural Crop Type for Sustainable Development in South Africa. Geocarto International 21 (2). 5-18

Kamusoko C. \& Aniya M. 2009. Hybrid classification of Landsat data and GIS for land use/cover change analysis of the Bindura district, Zimbabwe. International Journal of Remote Sensing 30(1): 97 - 115

Kenya County Fact Sheet. https://opendata.go.ke/Counties/Kenya-County-Fact-Sheets-Dec2011/zn6m-25cf last accessed on March 23rd 2013

Kiage L., Liu K., Walker N., Lam N \& Huh O. 2007. Recent Land-Cover/Use change associated with land degradation in Lake Baringo catchment, Kenya, East Africa: evidence from Landsat TM and ETM+. International Journal of Remote Sensing 28 (19): 4285 - 4309

King Brian 2011. Spatializing livelihoods: resource access and livelihood spaces in South Africa, Transactions of the Institute of British Geographers 36: 297 - 313

Lambin E. 2003. Linking Socioeconomic and remote sensing data at the community or at the household level: Case Studies from Africa. In Fox et al. (eds.): People and the Environment: 
Approaches for Linking Household and community Surveys to Remote Sensing and GIS. Kluwer Academic Publishers, Boston/Dordrecht/London. Chapter 8: 223 - 240

Landman T., Schramm M., Colditz R., Dietz A \& Dech S. 2010. Wide Area Wetland Mapping in Semi Arid Africa Using 250 meter MODIS metrics and topographic variables, Remote Sensing 2(7): $1751-1766$

Leichenko R. \& O’Brien K. 2008 .Environmental Change and Globalization: Double Exposures. Oxford University Press

Lu D., Mausel P., Brondizio E. \& Moran E. 2004. Change detection techniques. International Journal of Remote Sensing 25 (12): 2365 - 2407

Lung T. \& Schaab G. 2006. Assessing fragmentation and disturbance of west kenyan rain forests by means of remotely sensed time series data and landscape metrics, Africa Journal of Ecology 44: 491 - 506

Marsden T. 1995. Beyond Agriculture? Regulating the New Rural Spaces, Journal of Studies 11 (3): $285-296$

McCusker B. 2004. Land Use and Cover Change as an Indicator of Transformation on Recently Redistributed Farms in Limpopo Province, South Africa. Human Ecology 32 (1): 49 - 75

McCusker B. \& Carr E. 2006. The coproduction of livelihoods and land use change: Case Studies from South Africa and Ghana. Geoforum 37(5): 790 - 804

Moore N., Alagarswamy G., Pijanowski B, Thornton P., Lofgren B., Olson J., Adresen J., Yanda P. \& Qi J. 2012. East Africa food Security as influenced by future climate change and land use change at local to regional scales, Climatic Change 110 (3/4): 823 - 844

Moseley W. Carney J. \& Becker L. 2010. Neoliberal Policy, rural livelihoods and urban food security in West Africa: A Comparative Study if the Gambia, Cote d'Ivoire and Mali. Proceedings of the National Academy of Sciences, 107 (13): 5774 - 5779

Neves D. \& Du Toit A. 2013. Rural Livelihoods in South Africa: Complexity, Vulnerability and Differentiation, Journal of Agrarian Change 13 (1): 93 - 115

O'Keefe P. \& Smith N. 1980. Geography, Marx and the Concept of Nature. Antipode 12 (2): 30 39 
Peltorinne, P. 2004. The forest types of Kenya. Taita Hills and Kenya (ed. P. Pellikka, J. Ylhäisi and B. Clark), 40: 8-13.

Peters P. 2006. Rural Income and Poverty in a Time of Radical Change in Malawi. Journal of Development Studies 24 (2): 322 - 345

Petit C. \& Lambin E. 2001. Integration of multi-source remote sensing data for land cover change detection. International Journal of Geographical Information Science 15 (8): 785 - 803

Republic of Kenya, 2007. Sessional Paper No. 1 of 2007 on Forest Policy, Government Printer Nairobi

Rindfuss R., Walsh S., Mishra V., Fox J. \& Dolcemascolo 2003. Linking Household and Remote Sensely Data: Methodological and Practical Problems. In Fox et al. (eds.): People and the Environment: Approaches for Linking Household and Community Surveys to Remote Sensing and GIS. Kluwer Academic Publishers, Boston/Dordrecht/London. Chapter 1: 1 - 29

Serneels S., Linderman M, Lambin E. 2007. A Multilevel Analysis of the Impact of Land Use on Interannual Land Cover Change in East Africa, Ecosystems 10: 402 - 418

Shalaby A. \& Tateishi R. 2007. Remote Sensing and GIS for mapping and monitoring land cover and land use changes in the Northwestern coastal zone of Egypt. Applied Geography 27: 28 - 41

Shandra J., Shirliff E. \& London B. 2011. The IMF, World Bank and Structural Adjustment: A cross-national analysis of forest loss, Social Science Research 40: 210 - 225

Smith N. 2008. Uneven Development: Nature, Capital and Production of Space. The University of Georgia Press. Athens GA

Smucker T., Campbell D., Olson J. \& Wangui E. 2007. Contemporary Challenges of Participatory Field Research for Land Use Change Analyses: Examples from Kenya, Field Methods 19 (4): $384-406$

Turner II B. L., \& Robbins P. 2008. Land Change Science and Political Ecology: Similarities, Differences and Implications for sustainability Science. Annual Review of Environment and Resources 33: 295-316

Vasquez -Leon M. \& Liverman D. 2004. The Political Ecology of Land Use Change: Affluent Ranchers and Destitute Farmers, Human Organization 63 (1): 21 - 33 
Walingo M., Liwenga E., Kangalewa R., Madhulu N, \& Kabumbuli R. 2009 Perceived Impact of Land Use Changes and Livelihood diversification strategies of communities in Lake Victoria Basin of Kenya. Journal of Agricultural Biotechnology and Sustainable Development 1 (3): 069 $-078$

Walsh S., Bilsborrow R., McGregor S., Frizelle B., Messina J., Pan W., Crews-Meyer K., Taff G. \& Baquero F. 2003. Integration of Longitudinal Surveys, Remote Sensing Time Series and Spatial Analyses: Approaches for Linking People and Place. In Fox et al (eds.): People and the Environment: Approaches for Linking Household and Community Surveys to Remote Sensing. Kluwer Academic Publishers. Boston/Dordrecht/London

Warner, T., Almutairi A., \& Lee J. 2009. Remote sensing and land cover change. In: T.A. Warner, M.D. Nellis and G.M. Foody (eds.), SAGE Handbook of remote sensing. SAGE, London, UK. Chapter 33: 459-472.

Wood C. \& Skole D. 1998. Linking Satellite, Census, and Survey Data to study Deforestation in the Brazilian Amazon. In Liverman et al.: People and Pixels: Linking Remote Sensing and Social Science. National Academy Press. Washington DC 


\section{Chapter 5}

\section{General Conclusion}

This research examined the livelihood and landscape changes in a rural county in western Kenya during a period that was characterized by the implementation of neoliberal economic policies. During this period, Kenya's development agenda shifted from being state led to one that is market-led with implications on the livelihood options of rural households and the rural landscape. This study used remote sensing, qualitative and quantitative data to examine livelihood changes, land use and land cover change and policy changes. Landsat imagery was used in the land use change detection analysis while household surveys yielded quantitative data and qualitative data was obtained through interviews and focus groups. Other secondary data included government policy documents and rainfall records. The analysis was informed by political economic theory drawn from Neil Smith's and David Harvey's production of nature and space theses.

Chapter 2 lays out the political-economic background by examining the way in which the role of the state evolved during this period as reflected in the policy documents and its approach to rural development. From President's Moi's reluctance to implement neoliberal policies in the late 1980s and early 1990s to President Kibaki's eager implementation after 2003, this study identifies two turning points (change moments) in Kenya's political economy in the past three decades. The first change moment was the period in the late 1980s and 1990s when the state was under pressure to adopt and implement neoliberal economic policies. This period was characterized by massive scaling back of state support of development initiatives and set the stage for the downward spiral in rural development as many programs stalled and critical services like agricultural extension services became scarce.

The second moment identified is associated with the change in Kenya's political landscape when a new administration took over in 2002 after former President Moi's 24 year rule. Some of the projects initiated by the new administration such as the CDF projects have attempted 
to address the problem of uneven development and have transformed the rural landscape as shown in Chapter 4. More recently, the current administration is re-introducing policies that contravene the free market policies of neoliberalism such as the Price Control Act 2011. The reintroduction of policies that existed prior to the adoption of neoliberal policies is indicative of the state's current dilemma of having to balance the demands of the IFIs and those who benefit from the free market arrangement while also addressing the needs of its citizens. The measures being adopted to address the latter, however, are more short-term, aimed at addressing the symptoms of uneven development rather than addressing the underlying causes.

This chapter sheds light on the various ways in which state actions and inactions have created new challenges for rural households while simultaneously enhancing opportunities of enhanced integration into the global economy. Over the past three decades, the role of the state has evolved from that of facilitating and fostering national and rural development to that of enhancing the penetration of capital. This analysis sheds light on the prevailing political and economic conditions that shape livelihood and landscape outcomes. One of the limitations of this analysis is the heavy reliance on documents produced by the government and other interested stakeholders like the World Bank to shed light on the policy shifts and their implementation. Viewing rural change from this perspective downplays the significant role that is played by other rural change agents such as the church through various programs such as providing healthcare and education.

Chapter 3 examines the implications of the shifts in the political economy described in Chapter 2 on livelihood activities of rural households in the County. The data that was used in this analysis was obtained through 240 survey questionnaires, 34 household interviews and 21 key informant interviews. Climate data was also used to identify rainfall patterns and draw inferences on environmental dimensions of rural change. The results show a community that is characterized by low levels of education, poor living conditions and whose livelihood diversification options have shrunk in the past three decades. Few households are able to engage in cash crop production due to the small land parcels while even those who are able to grow cash crops like tea still have to face the challenges of an increasingly unreliable rainfall regime and unstable global tea market. Some livelihood options such as engaging in petty business are no longer an option for many households due to lack of the initial capital to invest in such 
businesses. Similarly, migrant wage income and remittances, which are a significant part of livelihood diversification, are declining as the country grapples with high rates of unemployment. For instance, textile manufacturing firms in nearby towns such as Kisumu Cotton Mills (in Kisumu town) and Ken Knit and Raymond Textiles (in Eldoret), which offered employment opportunities in the 1980s have closed down due to inability to compete with cheap imported textiles in the wake of the free market economy.

Farming continues to be considered the main livelihood activity for many households in spite of the shrinking land sizes. However, its viability also lies in the balance as the soil has become less productive due to exhaustion and needs constant application of synthetic fertilizers which have become expensive in the free market economy. Coupled with the increasingly erratic rainfall pattern, this situation has left households in this area vulnerable to food insecurity. The economic changes that occurred in the past three or so decades created an environment in which rural communities could no longer diversify their livelihoods by reducing or taking away some of the options that these communities had such as migrant wage income. However, there are a few groups of people who have benefitted from this situation. This include merchants dealing in the sale of food like maize who now purchase maize cheaply from other parts of the region and sell them at higher prices to Vihiga residents.

Chapter 4 examines the spatial dimensions of rural change during this period of economic transition. In this chapter, spatial data in the form of Landsat imagery and aerial photos are combined with social data obtained through interviews and focus group discussions to examine the reorganization of rural space over the past three decades of economic change. The coarse spatial resolution of Landsat imagery, however, limited the nature and level of changes that could be detected. While higher resolution imagery would have been ideal for the heterogeneous rural landscape in the study, the availability of such imagery is limited. However, change detection performed on the Landsat imagery for 1985, 2001 and 2010 shows loss of forest cover in one region of the study area and significant regeneration of the same in another. The simultaneous loss and regeneration of forest cover, however, is emblematic of the process of commodification of nature. What appears to be a regeneration of forest cover are tree farms of exotic tree species that are grown by the Forest Department to replace indigenous trees. These trees are eventually harvested after about 8 to 15 years and sold to logging companies to generate 
income for the forest department. New forest management policies have encouraged the commercialization of forest products as the forest is enclosed and made inaccessible to community members. All these point to the process of commodification of nature.

The results also indicate simultaneous expansion of farm land as households are driven to cultivate in rocky landscapes that were previously used as farms, while some of the farm land was converted into growing trees and other permanent crops like tea. Some households have opted to plant tea on a large portion of their land with negative implications on the maize production in the area. The juxtaposition of 1978 area aerial photos and 2012 Google Earth images of market/peri urban areas shows some slight horizontal expansion and observations made during visits show significant vertical expansion that is evident in the recent and upcoming buildings and the kind of services that are provided at these centers. The reworking of rural landscapes is characteristic of what Smith (2008) refers to as the production of nature and space. This process has accelerated the rate of peri-urban expansion as capital is embedded into the rural landscapes accompanied by an increase in all-weather access roads to areas that were previously inaccessible. These changes are part of the processes of penetration of capital and commodification of nature.

The use of dialectics in analyzing rural change is both revealing and constraining. By focusing on each of the change processes separately, this analysis brings into focus the relations and processes that are central to the stabilization of each of the processes and how changes in one of the processes implies change in the other relations and processes. To this end therefore, livelihood change is best understood within the framework of its relationship with landscape change and vice versa and within the conditions made possible by the neoliberal policies implemented by the state.

One of the limitations of this study is the lack of baseline data on livelihood activities that would form a tangible basis for an objective comparison with current livelihood data to infer change. Subjective reflections of household heads on changes in livelihood activities that is used in this study can be limiting. Perhaps, some baseline data conducted prior to the adoption of neoliberal policies could have provided more objective insights into the livelihood changes. A follow-up study in the future that uses this study as a baseline is therefore recommended. Furthermore, by focusing on the household as the unit for analyzing livelihood change, this study 
does not highlight the differences in the individual experiences of the members of the household. Consequently, important dimensions like gender and age are not brought into focus in this analysis. A study that focuses specifically on individual experiences and which analyses rural change from other vantage points such as gender would address this limitation. Such an analysis would bring into focus the inherent power dynamics that shape livelihood outcomes and the different ways in which individual members of the household experience the change processes.

Nonetheless this study contributes to the expanding body of knowledge that seeks to explain socio-spatial change from a holistic political-economic perspective. This perspective views nature and society as a unity, rather than a duality and hence changes that occur in one reflect the changes that are likely to occur in the other. In this study, the changes in the political economy redefined the way rural households make a living. The implementation of some of the neoliberal policies as well as household livelihood activities entail changes in land use and land cover, creating new landscapes while also creating new opportunities and challenges for rural households.

Furthermore, this study supports findings of similar studies conducted in other parts of Africa that show the detrimental effects of neoliberal economic policies on vulnerable communities. The ability of rural households to diversify their livelihoods has been compromised in the neoliberal economic era. More importantly, by examining the spatial nature of rural change during this period of economic transition, this study addresses an area that has not been the focus for most studies on the impact of neoliberal policies communities in the global south. Overall, this study makes a contribution to the existing understanding of the political economy of rural change and more specifically in rural livelihoods and land use and land cover change studies. 